\title{
Articles
}

\section{Regime Shifting: \\ The TRIPs Agreement and \\ New Dynamics of International \\ Intellectual Property Lawmaking}

\author{
Laurence R. Helfer ${ }^{\dagger}$
}

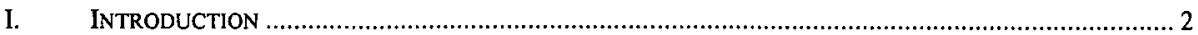

II. INTERNATIONAL REGIMES AND INTELLECTUAL PROPERTY REGIME SHIFTING ............................ 10

A. International Regimes. Substantive, Institutional, and Relational Aspects.................... 10

B. The Concept of Regime Shifting as a Strategy for Change......................................... 13

C. Regime Shifting From WIPO to GATT to TRIPs ................................................... 18

1. The Public Chotce Dimenston of Regime Shifting ......................................... 18

2. Motivations for the Shift From WIPO to GATT ................................................. 20

3. The Consequences of TRIPs for Developing Countries...................................... 23

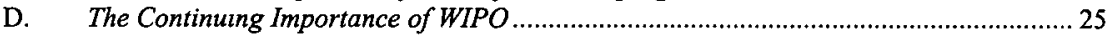

III. NEW INTELLECTUAL PROPERTY LAWMAKING IN FOUR INTERNATIONAL REGIMES .....................27

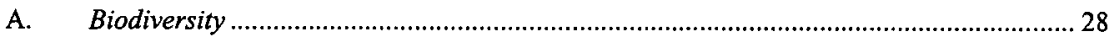

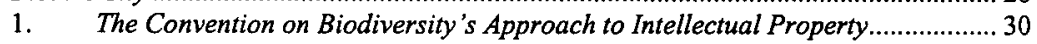

2. Intellectual Property Lawmaking by the Conference of the Parties...................... 32

B. Plant Genetic Resources for Food and Agriculture ..................................................... 34

1. From the Common Heritage Princtple to Divided Ownership Rules ................... 35

2. The International Treaty on Plant Genetic Resources for Food and Agriculture 39

C. Public Health ......................................................................................................4. 42

D. Human Rights.............................................................................................4 45

1. Cultural Heritage and Traditional Knowledge of Indigenous Peoples ...................46 46

2. United Nations Human Rights Challenges to TRIPs ..........................................49

E. Overview of Intellectual Property Lawmaking in the Four Regtmes .............................. 51

IV Post-TRIPs INTEllectual Property REgIME SHIFTING BY DEVELOPING STATES ..................53

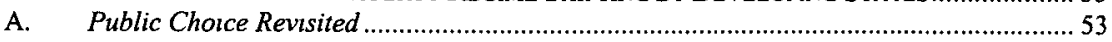

B. Rationales for Intellectual Property Regıme Shifting by Developing States ........................... 55

$\dagger \quad$ Fellow, Program in Law and Public Affairs, Pnnceton University; Professor of Law and Lloyd Tevis Fellow, Loyola Law School, Los Angeles. Larry.Helfer@lls.edu. Thanks to José Alvarez, Ellen Aprill, Jeff Atik, David Boyd, Allison Danner, Graeme Dinwoodie, Michael Doyle, Jeffrey Dunoff, Rochelle Dreyfuss, Brett Frischmann, Rick Hasen, Paul Heald, Justın Hughes, John Knox, Andrew Moravcsik, Ruth Okediji, Kal Raustıala, J. H. Reıchman, Carol Sanger, Jeff Shoenblum, Davıd Sugarman, Rutı Teitel, Jessica Vapnek, David Weıssbrodt, Chnstopher Yoo, and Peter Yu for thoughtful comments on earlier drafts or for sharing their thoughts about some of the ideas presented in this Article, and to Kristopher Diulio and Leeah Fontaine, Loyola Law School Class of 2003, for helpful research assistance. Earlier versions of this paper were presented at the International Law Workshop on Global Governance at Columbia Law School, the seminar series of Princeton University's Program in Law and Public Affairs, the Legal Theory Workshop at Vanderbilt Unıversity Law School, the Comparatıve Law and Politics Discussion Group at New York Law School, and faculty workshops at Loyola, the Unversity of Georgia, and Whittier Law Schools. 
1. Laboratories for Maximizing Desired Policy Outcomes ...................................... 55

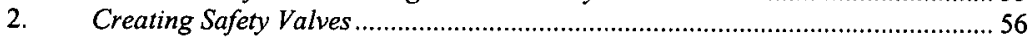

3. Generating Counterregime Norms .................................................................. 58

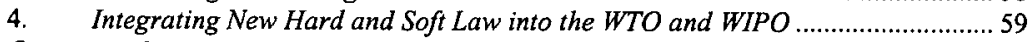

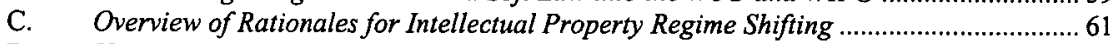

D. Hegemonic Responses to Regime Shifting by Developing States .......................................62

V. EMPIRICAL SUPPORT FOR AN INTEGRATIONIST REGIME SHIFTING STRATEGY ..............................6 63

A. TRIPs Article 27.3(b) and the Seattle Ministerial Conference ........................................63

B. The Doha Round and the Cancin Ministerial Meeting..................................................6 65

C. WIPO Patent Treaties and the Intergovernmental Committee on Intellectual Property,

Genetic Resources, Traditional Knowledge and Folklore.................................................69

VI. REgIME SHIFTING AND NEW DYNAMICS OF INTELleCtUAL PROPERTY LAWMAKING AND DisPUTE

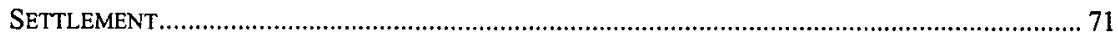

A. TRIPs as an Incentive for Other Regimes To Develop Soft Law ................................... 72

B. Counterregime Norms and TRIPs Dispute Settlement t....................................................75

1. The Resolution of Treaty Conflicts by WTO Panels ............................................ 75

2. The Influence of Soft Law on WTO Panels ........................................................ 77

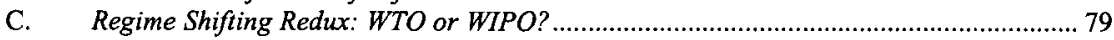

VII. CONCLUSION.

81

\section{INTRODUCTION}

Challenges to existing methods of international intellectual property lawmaking are becoming more prevalent and more pointed. Those challenges increasingly target the 1994 Trade-Related Aspects of Intellectual Property Rights Agreement (hereinafter referred to as TRIPs, or the Agreement) ${ }^{1}$ which folded into the World Trade Organization (WTO) an enhanced set of patent, copyright, trademark, and other private rights of intellectual property owners. Unlike prior international intellectual property agreements negotiated under the auspices of the World Intellectual Property Organization (WIPO), TRIPs has teeth. It contains detailed, comprehensive substantive rules and is linked to the WTO's comparatively hard-edged dispute settlement system in which treaty bargains are enforced through mandatory adjudication backed up by the threat of retaliatory sanctions.

TRIPs has been and continues to be defended by its strongest proponents-the United States, the European Communities (EC), Japan, and their respective intellectual property industries-on both normative and instrumental grounds. Normatively, TRIPs proponents argue that a uniform set of relatively high standards of protection fuels creativity and innovation, attracts foreign investment, and encourages a more rapid transfer of technology. Strong domestic intellectual property rules, in this view, are essential to economic growth and development. ${ }^{2}$ Instrumentally, proponents

1. Agreement on Trade-Related Aspects of Intellectual Property Rights, Dec. 15, 1993, Marrakesh Agreement Establishing the World Trade Organization, Annex 1C, LEGAL INSTRUMENTSRESULTS OF THE URUGUAY ROUND vol. 31, 33 I.L.M. 81 (1994) [hereinafter TRIPs].

2. See Peter K. Yu, Toward a Nonzero-Sum Approach to Resolving Global Intellectual Property Disputes: What We Can Learn from Mediators, Business Strategists, and International Relations Theorists, 70 U. CIN. L. REv. 569, 635 (2001) (restating and reviewing claim by developed countries that intellectual property rights "attract foreign investment, increase taxes, create new jobs, and facilitate technology transfer," and citing numerous supporting authorities) (footnotes omitted). 
defend TRIPs as part of a WTO package deal in which developing countries receive freer access to the markets of industrialized nations in exchange for their agreement to protect the intellectual property rights of foreign nationals. ${ }^{3}$ According to this rationale, governments importing intellectual property products agree to suffer the (hopefully short-term) welfare losses that strong intellectual property rules can engender in exchange for the immediate benefits and concessions they receive from other WTO agreements. ${ }^{4}$

Both of these claims are now increasingly questioned, perhaps not coincidentally at a time when phase-in rules have expired and WTO members with developing and transitional economies are facing the reality of compliance with TRIPs. ${ }^{5}$ Consider just a few examples. In February 2003, the United Nations Development Programme (UNDP) released a report on the world trading system that was remarkably critical of the treaty. Asserting that the "relevance of TRIPs is highly questionable for large parts of the developing world," the report urged developing countries to "begin dialogues to replace TRIPs . . . with alternate intellectual property paradigms" and, in the interim, to "modif[y] . . . the way the agreement is interpreted and implemented. ${ }^{6}$ Increasingly broad and vocal consortiums of nongovernmental organizations (NGOs) are challenging the "moral, political and economic

3. See, e.g., Emst-Ulrich Petersmann, Constitutionalism and International Organizations, 17 Nw. J. INT'L L. \& BUS. 398, 442 (1996-97) (characterizing agreements relating to services and intellectual property as part of "global package deals" negotiated within the GATT/WTO).

4. For a nuanced economic assessment of the effects of TRIPs-mandated intellectual property rights on different national jurisdictions, see KEITH E. MASKUS, INTELLECTUAL PROPERTY RIGHTS IN THE GLOBAL ECONOMY 27-234 (2000).

5. See TRIPs, supra note 1, art. 65, 33 I.L.M. at 107 (setting transition periods for phase-in of most of TRIPs); see also J.H. Reichman, The TRIPs Agreement Comes of Age: Conflict or Cooperation with the Developing Countries?, 32 CASE W. RES. J. INT'L L. 441, 450 (2000) (stating that TRIPs enters into force for most developing countries in 2000) [hereinafter Reichman, TRIPs Agreement].

6. U.N. Development Programme, Making Global Trade Work for People 221, 222 (2003), http:/www.undp.org/dpa/publications/globaltrade.pdf. An approach critical of the TRIPs Agreement also appears in a September 2002 study authored by the U.K.-based Commission on Intellectual Property Rights. The report questions a cornerstone principle of TRIPs-that minimum standards of intellectual property protection must be adopted by all WTO members whatever their economic circumstances or level of development. See COMMISSION ON INTELleCtUAL PROPERTY Rights, Integrating Intellectual Property Rights and Development Policy 5-6 (2002), http://www.iprcommission.org/graphic/documents/final_report.htm [hereinafter CoMMISsION ON IPRs] ("Standards of IP protection that may be suitable for developed countries may cause greater costs than benefits when applied in developing countries which must rely in large part on knowledge or products embodying knowledge generated elsewhere to satisfy basic needs and foster their development."). A similar perspective animates a joint capacity building project on intellectual property and development launched by the United Nations Conference on Trade and Development (UNCTAD) and the International Centre for Trade and Sustainable Development (ICTSD) in August 2001. A key objective of the capacity building project is "to improve understanding of the development implications of the TRIPS Agreement" and "[ $t]$ o strengthen the analytical and negotiating capacity of developing countries so that they are better able to participate in IPR-related negotiations in an informed fashion in furtherance of their sustainable development objectives." IPRsonline.org, UNCTAD-ICTSD Capacity Building Project on Intellectual Property Rights, http://www.iprsonline.org/unctadictsd/description.htm (last visited Nov. 23, 2003). In addition to commissioning and publishing studies and reports, the Project is developing a Resource Book on TRIPs and development to assist developing country government officials in negotiations in the WTO and elsewhere. See IPRsonline.org, Resource Book on TRIPS and Development: An Authoritative and Practical Guide to the TRIPS Agreement, at http://www.iprsonline.org/unctadictsd/ResourceBookIndex.htm (last visited Nov. 23, 2003). 
legitimacy"7 of TRIPs, focusing on provisions of the treaty that affect public health, human rights, biodiversity, and plant genetic resources. And revisionist readings of TRIPs's negotiating history now stress the power-based bargaining strategies that industrialized countries employed to coerce developing states into agreeing to treaty terms about which they had little understanding, let alone meaningful input.

Given the expansion of intellectual property rights that globalization and new information technologies have engendered, many of these critiques have been leveled at intellectual property standards generally, including those found in other international agreements (such as those administered by WIPO) and in national laws. ${ }^{9}$ Yet it is striking that states, NGOs, and intergovernmental actors have specifically identified TRIPs and "TRIPs-plus" bilateral agreements ${ }^{10}$ as the principal targets of their ire, challenging treaty bargains once thought settled at the conclusion of the Uruguay Round.

7. CEAS CONSUltants (WyE) LTD. ET al., DG TRADE EuROPEAN COMMISSION, STUDY ON THE RELATIONSHIP BETWEEN THE AGREEMENT ON TRIPS AND BIODIVERSITY RELATED ISSUES: FiNAL REPORT 50-51, 125 (2000) [hereinafter CEAS CONSULTANTS] (identifying a dozen civil society organizations whose shared objectives included "opposing trends in intellectual property and international trade law, especially the patenting of life-forms," encouraging benefit sharing, and protecting the knowledge and rights of indigenous communities); see also South Centre, NGOs Demand 'Re-Thinking' on TRIPs, http://www.southcentre.org/info/southbulletin/bulletin21/bulletin21-01.htm (last visited Nov. 23, 2003) (noting creation of "TRIPs Action Network" of 130 NGOs which called for "a fundamental re-thinking of TRIPS in the WTO").

8. Peter Drahos, Developing Countries and International Intellectual Property StandardSetting, 5 J. WORLD INTELL. PROP. 765, 769-70 (2002) [hereinafter Drahos, Developing Countries] (analyzing TRIPs's negotiating history in detail and arguing that it undermines the claim that the treaty was the "result of bargaining amongst sovereign and equal States ... which agreed to TRIPS as part of a larger package of trade-offs that contained gains for all'); Susan K. Sell, TRIPS and the Access to Medicines Campaign, 20 WIS. INr'L L.J. 481, 481 (2002) [hereinafter Sell, Access to Medicines] ("TRIPS was a product of tireless and effective agency and economic coercion."); see also SUSAN K. Sell, Private Power, Public law: The Globalization of INTEllectual Property Rights 108-20 (2003) (analyzing bargaining strategies used during the negotiation of TRIPs); Ruth Okediji, A Cartography of WTO TRIPS Dispute Settlement and the Future of Intellectual Property Policy, 62-102 (2001) (unpublished manuscript, on file with The Yale Journal of International Law) [hereinafter Okediji, Cartography] (applying coalition theory to analyze the negotiation of TRIPs). For an important early discussion of the benefits and drawbacks of linking intellectual property to the world trading system, see J.H. Reichman, Intellectual Property in International Trade: Opportunities and Risks of a GATT Connection, 22 VAND. J. TRANSNAT'L L. 747 (1989).

9. A few recent intellectual property initiatives include TRIPs as part of a broader effort to revise intellectual property protection standards to take into account the needs of developing country governments and their nationals. See COMMISSION ON IPRs, supra note 6, at 172, 178-86 (discussing the "intemational architecture" of intellectual property protection, including WTO, WIPO, and regional and bilateral agreements); Press Release, The Rockefeller Foundation Initiative to Promote Intellectual Property (IP) Policies Fairer to Poor People (Nov. 4, 2002), http://www.rockfound.org. [hereinafter Rockefeller IP Initiative] (discussing the launch of a "multi-year initiative to support the emergence of fairer, development-oriented IP policies").

10. These bilateral treaties are referred to by the appellation "TRIPs-plus" because they contain intellectual property protection standards more stringent than those found in TRIPs, obligate developing countries to implement TRIPs before the end of its specified transition periods, or require such to accede to or conform to the requirements of other multilateral intellectual property agreements. See Peter Drahos, BITs and BIPs, 4 J. WORLD INTELL. PROP. L. 791, $792-807$ (2001) (describing "TRIPs-plus" bilateral agreements negotiated by the United States and the EC with individual developing country governments); Genetic Resources Action International (GRAIN), "TRIPs-plus" Through the Back Door: How Bilateral Treaties Impose Much Stronger Rules for IPRs on Life than the WTO, http://www.grain.org/docs/trips-plus-en.pdf (July 2001) [hereinafter GRAIN, TRIPs-plus] (same); ORgANIZATION FOR ECONOMIC CO-OpERATION AND DEVElOPMENT, REgIONALISM AND THE 
Perhaps the most well-known manifestation of this challenge appears in the Declaration on the TRIPs Agreement and Public Health ${ }^{12}$ (Public Health Declaration) adopted in November 2001 as part of the launch of a new round of WTO trade talks in Doha. ${ }^{13}$ The Declaration responds to the claim by developing nations that they are unable to afford the patented pharmaceuticals needed to address the massive HIV/AIDS crisis within their borders. It grants least developed countries an additional ten years before they must protect pharmaceuticals, ${ }^{14}$ and it reaffirms the principle of balanced intellectual property protection already embedded in various clauses of TRIPs. ${ }^{15}$ The Public Health Declaration applies only to the narrow, albeit politically charged, issue of access to patented medicines. But it may be a harbinger of more broad-based efforts to revise, reinterpret, or supplement intellectual property protection standards adopted in the WTO and in WIPO. ${ }^{16}$

This Article assesses an under-explored dimension of these challenges to TRIPs and to expansions of intellectual property rights more generally. Drawing on the writings of political scientists who analyze international regimes, ${ }^{17}$ the Article reveals that TRIPs has had unanticipated effects on international intellectual property lawmaking. In particular, the Agreement's strengthening of intellectual property rights has led states, NGOs, and officials

\begin{tabular}{llllll}
\hline Multilateral Trading SyStem $111-22$ & (2003), http://wwwl.oecd.org/publications/e-
\end{tabular} book/2203031E.pdf (same).

11. Final Act Embodying Results of the Uruguay Round of Multilateral Trade Negotiations, Apr. 15, 1994, Marrakesh Agreement Establishing the World Trade Organization, LEgal INSTRUMENTS-RESULTS OF THE URUGUAY ROUND vol. 1, 33 I.L.M. 1140 (1994). See Steve Lohr, The Intellectual Property Debate Takes a Page from 19th Century America, N.Y. TimES, Oct. 14, 2002, at C4 (noting the "growing backlash in developing countries against the imposition of a strong global system of intellectual property rights"); Sell, Access to Medicines, supra note 8, at 482 (stating that "the unwitting "victims' of TRIPS" have "gradually mobilized to demand a change" in the structures it created).

12. Declaration on the TRIPs Agreement and Public Health, WTO Doha Ministerial Conference, 4th Sess., WTO Doc. WT/MIN(01)/DEC/W/2 (Nov. 14, 2001) [hereinafter Public Health Declaration].

13. Ministerial Declaration, WTO Doha Ministerial Conference, 4th Sess., WTO Doc. WT/MIN(01)/DEC/W/1 (Nov. 14, 2001) [hereinafter Doha Ministerial Declaration] (declaration setting forth negotiating agenda for new trade talks).

14. Public Health Declaration, supra note 12, para. 7 (extending until 2016 the transitional period for least developed WTO members to implement provisions of TRIPs governing patents and undisclosed information relating to pharmaceutical products).

15. The Declaration states that TRIPs "can and should be interpreted and implemented in a manner supportive of WTO Members' right to protect public health and, in particular, to promote access to medicines for all," and it reaffirms "the right of WTO Members to use, to the full, the provisions in the TRIPS Agreement, which provide flexibility for this purpose." Id. para. 4. For a more detailed discussion of the Public Health Declaration and the negotiations it has spawned, see infra Section V.B.

16. See Lohr, supra note 11 (noting that the Public Health Declaration may embolden developing countries to extend public health arguments to other areas of intellectual property policy); Sell, Access to Medicines, supra note 8, at 519 (citing the Public Health Declaration as "evidence of movement away from the industry-sponsored IP orthodoxy that animated deliberations leading up to the TRIPS accord" and that "could have a significant impact ... in redressing the imbalance between private and public interests in the context of intellectual property").

17. As used by political scientists, the term international "regime" describes a concept that is broader than a single intergovernmental organization or a particular international agreement. A regime refers to the principles, norms, and rules governing a particular issue area of international relations, and to the formal institutional structures and decision-making procedures through which those principles, norms, and rules are developed. Regimes form when the interests of states converge around certain shared objectives that can best be achieved through interstate cooperation. For a more detailed discussion of regimes and their components, see infra Section II.A. 
of intergovernmental organizations to raise concerns about those rights in an expanding list of international venues. The few short years since TRIPs entered into force have seen nothing less than an explosion of interest in intellectual property issues in a broad array of international fora. Intellectual property issues are now at or near the top of the agenda in intergovernmental organizations such as the World Health Organization and the Food and Agriculture Organization, in international negotiating fora such as the Convention on Biological Diversity's Conference of the Parties and the Commission on Genetic Resources for Food and Agriculture, and in expert and political bodies such as the United Nations Commission on Human Rights and its Sub-Commission on the Promotion and Protection of Human Rights. ${ }^{18}$ In some of these venues, "intellectual property lawmaking" 19 involves the negotiation of new treaties; in others, such lawmaking occurs through the reinterpretation of existing agreements and the creation of new nonbinding declarations, guidelines, recommendations, and other forms of "soft law."20

The theoretical and practical consequences of these developments have yet to be fully explored. I argue that the expansion of intellectual property lawmaking into these diverse international fora is the result of a strategy of "regime shifting" by developing countries and NGOs that are dissatisfied with many provisions in TRIPs or its omission of other issues and are actively seeking ways to recalibrate, revise, or supplement the treaty. ${ }^{21}$ As I explain in detail below, state and non-state actors shift lawmaking initiatives from one international venue to another for many reasons..$^{22}$ In the case of intellectual property rights, developing countries and their allies are shifting negotiations to international regimes whose institutions, actors, and subject matter mandates are more closely aligned with these countries' interests. Within these regimes, developing countries are challenging established legal prescriptions and generating new principles, norms, and rules of intellectual property protection for states and private parties to follow. Intellectual property regime shifting thus heralds the rise of a complex legal environment in which seemingly settled treaty bargains are contested and new dynamics of lawmaking and dispute settlement must be considered. ${ }^{23}$

In addition to its international law aspects, the phenomenon of regime shifting also provides new evidence to help answer two related questions

18. See infra Part III.

19. In this Article, I use the phrase "intellectual property lawmaking" to refer both to the negotiation or amendment of binding international agreements and to the drafting of declarations, resolutions, interpretative statements, guidelines, and other processes by which nonbinding legal norms are created.

20. International law and international relations scholars have recently emphasized the importance of non-binding norms, or soft law, as a method to promote international cooperation and alter state behavior. For illuminating discussions, see COMMITMENT AND COMPLIANCE: THE ROLE OF NON-BINDING NORMS IN THE INTERNATIONAL LEGAL SYSTEM (Dinah Shelton ed., 2000); Kenneth W. Abbott \& Duncan Snidal, Hard and Soft Law in International Governance, 54 INT'L ORG. 421 (2000) [hereinafter Abbot \& Snidal, Hard and Soft Law]. change).

21. See infra Section II.B (defining the concept of regime shifting and its use as a strategy for

22. See infra Part IV.

23. See infra Part VI (discussing three new dynamics of intellectual property lawmaking and dispute settlement). 
posed by international relations scholars: first, why do regimes arise, and second, do regimes matter? ${ }^{24}$ The first question seeks to understand the causal factors-such as power, interests, or values-that lead states to create, alter, or dismantle international regimes under conditions of relative anarchy. Viewed through this explanatory lens, the decision by particular governments and NGOs to develop certain principles, norms, and rules in one regime instead of - or in addition to-another is consequential. It implies a belief by those actors that such shifts will enhance their relative power or their prospects for achieving desired policy outcomes in ways that could not have been obtained in the absence of such moves. Yet it is widely believed that powerful states are far more adroit at shaping regimes to reflect their interests-a belief borne out by the success of the United States and the EC in shifting intellectual property lawmaking from WIPO to GATT to TRIPs. ${ }^{25}$ The particular puzzle raised by the post-TRIPs rounds of intellectual property regime shifting, therefore, is whether weaker developing countries can capitalize on the widespread resistance to TRIPs to reshape the international regime landscape so as to reflect their interests more accurately. ${ }^{26}$

The choice by states-whether powerful or weak-to pursue norm development in multiple regimes also raises a second question: whether regimes, once formed, in fact alter state behavior. A functionalist understanding of regimes asserts that states create regimes to reduce the transaction costs and information problems that plague uncoordinated state relations. It follows that regimes will only arise if the benefits they engender outweigh the organizational costs to the governments involved. Once formed, however, regimes are sticky. Their sunk costs and the benefits they generate allow regimes to persist even after the interests of states that advocated their adoption have changed. This persistence helps to explain why regimes may be

24. See Stephen D. Krasner, Structural Causes and Regime Consequences: Regimes as Intervening Variables [hereinafter Krasner, Structural Causes], in INTERNATIONAL REGIMES 1, 5, 11 (Stephen D. Krasner ed., 1983) [hereinafter INTERNATIONAL REGIMES] (discussing regime significance and using simple diagrams to illustrate these two questions).

25. Id. at 16 (noting several examples in which "more powerful actors created regimes that served their particular purpose, and other[s] were compelled to accept them"). See infra Section II.C (discussing effort by the United States and EC to move intellectual property lawmaking from WIPO to GATT, leading to the creation of the TRIPs Agreement).

26. A formal empirical test of whether developing countries have enhanced their power through post-TRIPs regime shifting would require comparing the outcomes those states have achieved by bargaining in other regimes (and using those outcomes as the basis for subsequent negotiations in the WTO and WIPO) to the results they would have obtained had they bargained exclusively in the WTO or in WIPO. Accurately comparing real world events to such hypothesized altematives can be problematic, however, because "an element of speculation and uncertainty is inevitable in entering the counterfactual realm." Mark W. Zacher, Multilateral Organizations and the Institution of Multilateralism: The Development of Regimes for Nonterrestrial Spaces, in MULTILATERALISM MATTERS: THE THEORY AND PRAXIS OF AN INSTITUTIONAL FORM 399, 402 (John G. Ruggie ed., 1993). Nevertheless, the detailed narrative and causal inferences presented in this Article strongly suggest that developing states have enhanced their power by adopting a regime shifting strategy. Cf. id. at 428-29 (analyzing multilateral organizations regulating nonterrestrial spaces and concluding that "developing countries almost certainly could not have secured the movements toward national enclosure and common-heritage planning in the three nonterrestrial areas that they did achieve if it had not been for the existence of the multilateral organizations in which the jurisdictional regimes were explicitly and/or implicitly addressed"). 
viewed as "intervening variables" that modify interstate bargaining patterns and their resulting policy outcomes. ${ }^{27}$

Seen from this perspective, regime shifting seems to present a paradox. If states enjoy cost savings from established regimes, why would they abandon one regime in favor of its rival? And if regimes are relatively impervious to manipulation, how could states and NGOs so easily shift lawmaking initiatives from one regime to another? If such manipulations are indeed possible, they appear to challenge the claim that regimes exert independent influence on states.

As explained in this Article, however, several features of the international legal landscape help to resolve this paradox and provide a more nuanced explanation of the dynamic relationship between extant regimes and state behavior. The most important feature is the significant increase in the "issue density" of intellectual property protection standards over the last decade. ${ }^{28}$ As intellectual property rights have expanded, especially in the wake of TRIPs, they have become a subject of increasing concern to government officials and NGOs active in other policy spaces-including in particular the biodiversity, plant genetic resources, public health, and human rights regimes. This greater issue density, and the linkages it has spawned, have increased the "demand" for international regimes to help manage these complex policy interfaces. ${ }^{29}$

What regime shifting reveals, however, is that this increased demand need not be met-or at least not met initially-by the expansion or strengthening of any particular regime. ${ }^{30}$ Rather, the existence of multiple, discrete regimes, any one of which may plausibly serve as a site for future policy development, leaves considerable room for maneuvering by different clusters of states (or states and NGOs) seeking to maximize their respective interests. A crowded regime environment also offers alternative venues-each with its own suite of institutional features, subject matter competencies, and decision-making procedures-within which actors can experiment to find the most effective way to reduce transaction costs and enhance information flows. But states and NGOs do not act on a clean slate, and the strategies they can employ are constrained by both the sunk costs and the benefits of extant regimes. ${ }^{31}$ For these reasons, regimes that increase the density of particular

27. Krasner, Structural Causes, supra note 24, at 5. For a more detailed discussion of the issues raised in this paragraph, see infra Section II.B.

28. Robert O. Keohane, The Demand for International Regimes, in INTERNATIONAL REGIMES, supra note 24 , at 141,155 (defining "issue density" by reference to "the number and importance of issues arising within a given policy space").

29. Id. at 157 (arguing that "increased issue density will lead to greater demand for international regimes and to more extensive regimes").

30. That the endpoint of certain forms of intellectual property regime shifting by developing countries appears to be a return to the WTO or WIPO suggests that one or two regimes-perhaps those with stronger enforcement authority or better linkage capability than the others-will ultimately benefit from the increased demand for regimes that issue density engenders. See infra Part V (reviewing evidence of integrationist regime shifting into the WTO and WIPO).

31. To manage the complexities of rising issue density, states could, for example, create an entirely new regime that included a new intergovernmental organization. But the significant start-up costs involved in such a decision would mean that states would have no incentive to do so, particularly if 
policy spaces do indeed influence state behavior, interacting with other regimes to create distinctive patterns of bargaining that include the phenomenon of regime shifting described in this Article.

The remainder of this Article proceeds as follows. Part II begins with a brief overview of international regimes. It describes the substantive, institutional, and relational components of a regime and explains the diverse ways in which states and nonstate actors attempt to reshape a regime's constituent principles, norms, and rules by shifting from one discrete regime to another or between fora within the same conglomerate regime. Part II then explores the public choice dimension of regime shifting. It describes how the United States and the EC-at the urging of their respective domestic intellectual property industries-moved negotiations over intellectual property rights from WIPO to the GATT, leading to the adoption of the TRIPs Agreement. Part II also reviews the consequences of TRIPs for developing countries and concludes with a discussion of the continuing importance of WIPO as a forum for intellectual property lawmaking.

Part III analyzes the unexpected growth of intellectual property lawmaking in four international regimes: biodiversity, plant genetic resources, public health, and human rights. Defining lawmaking to include both hard law treaty negotiations and soft law standard setting, Part III first identifies the principles, norms, and rules embraced by each of the four regimes and the institutions, states, and NGOs actors operating within them. It then explains how these actors have responded to the expansion of intellectual property protection standards by generating new principles, norms, and rules that are often in tension with TRIPs. Part II concludes with a table summarizing the different responses in each regime.

Part IV first revisits the public choice dimension of regime shifting, identifying the domestic and transnational interest groups who are pressing developing states to engage in intellectual property regime shifting. Part IV then explores four different rationales for post-TRIPs intellectual property regime shifting by developing countries and NGOs. It explains how these actors use regime shifting to maximize desired policy outcomes, to relieve pressure for action in other international venues, to create treaties and soft law in tension with TRIPs, and to lay the political groundwork needed to integrate new principles, norms, and rules of intellectual property protection into the WTO and WIPO.

Part $\mathrm{V}$ assesses the empirical evidence of this integrationist regime shifting strategy. It identifies different entry points that developing country governments have used to introduce jointly authored proposals first articulated in the biodiversity, plant genetic resources, public health, and human rights regimes into the WTO and WIPO.

Part VI considers the broader consequences of a world in which the principles, norms, and rules of intellectual property protection are created and contested in multiple international regimes. It analyzes three new dynamics of lawmaking and dispute settlement that regime shifting is likely to engender: 
(1) the incentives TRIPs creates for other regimes to develop soft law; (2) the effect of conflicting treaties and soft law on TRIPs dispute settlement; and (3) strategic issues generated by dividing regime shifting between the WTO and WIPO. Part VII briefly concludes.

\section{INTERNATIONAL REGIMES AND INTELLECTUAL PROPERTY REGIME SHIFTING}

\section{A. International Regimes: Substantive, Institutional, and Relational Aspects}

International relations scholars have developed the concept of international regimes to capture the diversity and complexity of the cooperative arrangements that states use to address transborder issues of mutual concern. The canonical (if sometimes criticized) definition of regimes is "sets of implicit or explicit principles, norms, rules, and decision-making procedures around which actors' expectations converge in a given area of international relations." 32 So defined, regimes have been described as coextensive with particular intergovernmental organizations or international agreements. ${ }^{33}$ But in fact regimes are broader than specific organizations or treaties, reflecting the fact that states (and, increasingly, non-state actors) can cooperate without creating formal institutions or legally binding commitments. ${ }^{34}$

Disaggregating international regimes into substantive, institutional, and relational components illustrates their explanatory power. The substantive component focuses on a regime's principles, norms, and rules - that is, its prescriptions for state conduct at decreasing levels of abstraction. ${ }^{35}$ The reference to decision-making procedures encompasses the formal institutions and informal cooperative arrangements states use to create those

32. See Krasner, Structural Causes, supra note 24, at 2; see also Ernst B. Haas, Why Collaborate? Issue-Linkage and International Regimes, 32 WORLD POL. 357, 397 (1980) (defining regimes as "norms, procedures, and rules agreed to in order to regulate an issue-area"). Some commentators have criticized the imprecision of the canonical definition and the difficulty of distinguishing among its various components. See Stephan Haggard \& Beth A. Simmons, Theories of International Regimes, 41 INT'L ORG. 491, 493-94 (1987). For this reason, I attempt to provide greater precision by disaggregating regimes into their substantive, institutional, and relational aspects and by describing how these aspects operate within the international intellectual property regime.

33. See David W. Leebron, Linkages, 96 AM. J. INT'L L. 5, 10 (2002) (using "regime" to refer to "the international institutions and formal agreements (treaties) that govern an issue area"); Ruth Okediji, TRIPs Dispute Settlement and the Sources of (International) Copyright Law, 49 J. COPYRIGHT SOC'Y U.S.A. 585, 607-16 (2002) (analyzing TRIPs as a regime).

34. See ROBERT O. KEOHANE, AFTER HEgEMONY: COOPERATION AND DISCORD IN THE WORLD POLITICAL ECONOMY 107 (1984) (stating that the "most important function" of regimes "is to facilitate negotiations leading to mutually beneficial agreements among governments"); Krasner, Structural Causes, supra note 24, at 2-3 (noting a distinction between specific agreements, which are "ad hoc, often 'one-shot,' arrangements," and regimes, whose purpose is to "facilitate agreements").

35. See Krasner, Structural Causes, supra note 24, at 2 ("Principles are beliefs of fact, causation, and rectitude. Norms are standards of behavior defined in terms of rights and obligations. Rules are specific prescriptions or proscriptions of action."). Robert Keohane asserts that regime "principles" define "the purposes that their members are expected to pursue," regime "norms" are standards of behavior articulated "in terms of rights and obligations," and regime "rules" indicate in greater detail members' specific rights and obligations. KEOHANE, supra note 34, at 57-58. 
prescriptions. ${ }^{36}$ And the focus on converging expectations in "a given area of international relations" (often referred to as an "issue area") is a relational concept, ${ }^{37}$ reflecting the fact that interstate cooperation often centers on subjects that actors perceived as associated with one another. The discussion below elaborates on each of these three dimensions of international regimes, with a focus on intellectual property.

A regime's substantive dimension can be illustrated by the following admittedly oversimplified description of the principles, norms, and rules of the international intellectual property regime. The principles that regime embodies include recognition of state-created private property in intangible objects that embody human innovation and creativity and the need to protect that property from unauthorized exploitation across national borders. The norms of the regime include an obligation for states to create legal monopolies (in the form of exclusive rights controlled by private parties) that generate incentives for human innovation and creativity and to allow foreign creators and inventors to market their products in different national jurisdictions on an equal footing with local creators and inventors. And its rules encompass the specific prescriptions and proscriptions by which these principles and norms are given effect, such as the national treatment rule, specific exclusive rights and minimum standards of protection, and coordinated procedural mechanisms or priority rules. ${ }^{38}$

The institutional component of international regimes consists of the cooperative arrangements states use to create principles, norms, and rules. These arrangements can be visualized as a spectrum running from highly structured intergovernmental organizations with staffs, facilities, and budgets at one end, to informal networks of government officials who exchange information and coordinate national policies at the other. ${ }^{39}$ The entities lying along this spectrum differ from one another according to features such as membership and voting rules, scope of issues covered, resources allocated, centralization of tasks, flexibility of applicable rules, control mechanisms, and permeability to non-state actors. ${ }^{40}$ These diverse attributes provide states with

36. Krasner, Structural Causes, supra note 24, at 2.

37. See Leebron, supra note 33, at 7 ("An issue area can be as narrow as the international shipment of hazardous substances or as broad as protection of the environment. The chief characteristic of such areas is the substantive relationship of the issues encompassed within them.").

38. For further discussion of the substantive principles shared by international intellectual property agreements, see LAURENCE R. HELFER, INTELleCtUAL PROPERTY RIGHTS IN PLANT VARIETIES: AN OVERVIEW WITH OPTIONS FOR NATIONAL GOVERNMENTS 3-10 (FAO Legal Papers Online No. 31, 2002), at http://www.fao.org/Legal/pub-e.htm [hereinafter HELFER, IPRS IN PLANT VARIETIES].

39. Compare Kenneth W. Abbott \& Duncan Snidal, Why States Act Through Formal International Organizations, 42 J. Conflict Resol. 3, 9 (1998) [hereinafter Abbott \& Snidal, Why States Act] (stating that "centralization (a concrete and stable organizational structure and an administrative apparatus managing collective activities) and independence (the authority to act with a degree of autonomy, and often with neutrality, in defined spheres)" are two essential characteristics of international organizations), with ANNE-MARIE SLAUGHTER, GLOBAL GOVERNMENT NETWORKS, Global Information AgEnCies, AND Disaggregated Democracy 2-3 (Harvard Law School Working Paper No. 018, 2001) (defining government networks as "networks of national government officials exchanging information, coordinating national policies, and working together to address common problems").

40. See Barbara Koremenos et al., The Rational Design of International Institutions, 55 INT'L ORG. 761, 763 (2001) (identifying membership rules, scope of issues covered, centralization of tasks, 
[Vol. 29: 1

a wide variety of approaches to capture the benefits of international cooperation. $^{41}$

Consider WIPO as an example of how states benefit by acting through intergovernmental organizations. WIPO undertakes a wide variety of activities to provide a hospitable forum for interstate cooperation and to "promote the protection of intellectual property throughout the world." ${ }^{, 42}$ To assist states in negotiating new international agreements, the WIPO Secretariat hosts diplomatic conferences of government representatives, encourages shared learning regarding new intellectual property issues, and provides expert advice to officials. WIPO administers the implementation of existing intellectual property agreements and provides dispute settlement services, generating the revenue needed to fund its activities. WIPO's staff provides technical assistance and training to member states and their national intellectual property offices, especially in developing countries. More recently, the organization has created standing, expert, and intergovernmental committees that carry out studies on particular intellectual property topics and generate soft law guidelines and recommendations for consideration by WIPO member states. $^{43}$

The third component of international regimes, their relational aspect, focuses on the substantive issue areas that are included within a particular regime and the ways in which they intersect with the issue areas of other regimes. Sometimes the packaging of issues within a single regime is uncontroversial, such as granting WIPO competence to administer both industrial property conventions (regulating patents and trademarks) and literary and artistic property conventions (addressing copyrights and neighboring rights), rather than entrusting the administration of those treaties to separate intergovernmental organizations. Linkages at this level of detail tend to reflect shared perceptions about the benefits that flow from treating substantively similar topics together. By contrast, the clustering of more

rules for controlling the institution, and flexibility of arrangements as "five key dimensions within which institutions may vary"); see also Abbott \& Snidal, Hard and Soft Law, supra note 20, at 424-50 (explaining advantages and disadvantages of using binding and nonbinding commitments and objectives to structure international relations among states).

41. These benefits include reducing the transaction costs involved in negotiating agreements, establishing self-reinforcing behavior, creating property rights, promoting linkages among issue areas, increasing access to information, monitoring states' behavior, mediating disputes, and imposing sanctions for noncompliance. See Abbott \& Snidal, Why States Act, supra note 39, at 8 (asserting that states "consciously use IOs [international organizations] both to reduce transaction costs in the narrow sense and, more broadly, to create information, ideas, norms, and expectations; to carry out and encourage specific activities; to legitimate or delegitimate particular ideas and practices; and to enhance their capacities and power"); William J. Aceves, Institutionalist Theory and International Legal Scholarship, 12 AM. U. J. INT'L L. \& POL'Y 227, 243-56 (1997) (reviewing benefits of state cooperation through international institutions). It is these benefits-unavailable absent cooperation-that explain why even self-interested states jealous of their power and autonomy are willing to create and work within the confines of international regimes and institutions.

42. Convention Establishing the World Intellectual Property Organization, July 14, 1967, 21 U.S.T. 1749, 828 U.N.T.S. 3 (as amended on Sept. 28, 1979), art. 3(i) [hereinafter WIPO Convention].

43. For discussions of WIPO's various functions, see Frederick M. Abbott, The Future of the Multilateral Trading System in the Context of TRIPs, 20 HASTINGS INT'L \& COMP. L. REv. 661, 665-66 (1997) [hereinafter Abbott, Future of TRIPs]; Michael P. Ryan, The Function-Specific and LinkageBargain Diplomacy of International Intellectual Property Lawmaking, 19 U. PA. J. INT'L ECON. L. 535, 543 (1998); WIPO, Development of Intellectual Property Law, at http://www.wipo.org/activities/en/ index.html?wipo_content_frame=/activities/en/development_iplaw.html (last visited Nov. 23, 2003). 
diverse issue areas under a single regime umbrella is often motivated by strategic concerns, such as enhancing bargaining power or expanding the zone of agreement by permitting trade-offs among unrelated regulatory objectives. ${ }^{44}$ These relational questions of packaging and linkage are often controversial, creating conflict among states which serves as an engine driving regime change.

\section{B. The Concept of Regime Shifting as a Strategy for Change}

Power dynamics are often at the heart of disputes over changes to international regimes. According to a realist understanding of regimes, "the rules of a regime are tailored to the national interests of hegemons." those interests change, rule changes necessarily follow. ${ }^{46}$ But power, although important, is not the sole determinant of how a regime evolves over time. ${ }^{47}$ Intergovernmental organizations and international institutions often limit the scope for hegemonic action and allow weaker states and non-state actors some leeway to influence the development of principles, norms, and rules. Voting and other procedural devices, for example, create opportunities for alliances or networks among less powerful states and NGOs. In addition, the secretariats and staffs of these organizations and institutions can also affect regime trajectories by shaping negotiating agendas and influencing the calculation of state preferences. ${ }^{48}$ Powerful states might be expected to block these developments by threatening to leave a regime that fails to advance their interests. But the sunk costs of existing regimes and the high costs of creating new ones make regimes sticky, and discourage hegemons from abandoning institutions and the habits of cooperation they engender. ${ }^{49}$ For all of these

44. See Leebron, supra note 33, at 11-12 (discussing differences between "substantive linkage" and "strategic linkage"); Okediji, Cartography, supra note 8, at 84 (discussing the importance of side-payments for conclusion of TRIPs).

45. Haas, supra note 32 , at 387.

46. Robert O. KEOHANE \& JOSEPH S. NyE, POWER AND INTERDEPENDENCE: WorLd POLITICS IN TRANSITION 43 (1977) (describing the "power structure explanation" for regime changes according to which the content of international regimes change as the power of states changes).

47. Other explanations for regime change include changes in the nature of the relevant activity (often caused by changes in technology or usage) or efforts to systematize or rationalize an incoherent or chaotic regime. See Oran Young, International Regimes: Problems of Concept Formation, 32 WORLD POL. 331, 351-52 (1980).

48. See Abbott \& Snidal, Why States Act, supra note 39, at 8 (describing how, under "constructivist" international relations theory, international organizations can act "as agents, which, in turn, influence the interests, intersubjective understandings, and environment of states"); see also MARTHA FINNEMORE, NATIONAL INTERESTS IN INTERNATIONAL SOCIETY 34-66 (1996) (analyzing how UNESCO helped to shape the preferences, identities, and interests of states in the area of science policy); WTO, From Doha to Cancún and Beyond (Sept. 20, 2002), at http://www.wto.org/english/news_e/spsp_e/spsp_e.htm (announcement by WTO Director-General of four principles to strengthen the WTO and help bring the Doha Round to a timely and successful conclusion).

49. See ANDreas HasencleVer et al., Theories of International Regimes 108 (1993) (noting that "regimes can be a source of power themselves," enabling "even structurally weak states [to] exert a modicum of influence on the collective policies in an issue-area due to the membership and voting rules of the international organization that administers the regime concerned"); KEOHANE, supra note 34, at 102 (discussing ways in which international regimes embody "sunk costs" for states that explains "why they persist even when all members would prefer somewhat different mixtures of principles, rules, and institutions"). 
reasons, although regimes at their inception reflect existing distributions of power, over time "the underlying capabilities of states will become increasingly poor predictors of the characteristics of international regimes" and institutional dynamics will loom larger. ${ }^{50}$

Given these constraints on power, what strategies may states and nonstate actors employ so that international regimes evolve to reflect their interests more accurately? One important strategy is "regime shifting," which I define as an attempt to alter the status quo ante by moving treaty negotiations, lawmaking initiatives, or standard setting activities from one international venue to another. ${ }^{51}$

The substantive, institutional, and relational aspects of international regimes are all implicated by regime shifting. Substantively, regime shifting provides an opportunity to generate "counterregime norms" 32 - binding treaty rules and nonbinding soft law standards that seek to alter the prevailing legal landscape. Initially, these norms may "circulate in the realm of rhetoric or lie dormant as long as those who dominate the existing regime preserve their power." ${ }^{53}$ But the move to a different negotiating forum-whether or not the original forum is abandoned-provides new opportunities for states and NGOs to contest established normative orthodoxies. ${ }^{54}$

How such challenges unfold depends in part on the degree of dissonance between established and emerging legal prescriptions. Disadvantaged actors may articulate counterregime norms that only incrementally modify existing rules but leave uncontested the broader principles from which those rules emanate. A state or an NGO might, for example, object to treaty obligations that require recognition of specific types of patentable subject matter or that narrow the exceptions to a patentee's exclusive rights without questioning the broader innovation objectives that a patent system serves. In other instances, counterregime norms may be revolutionary rather than evolutionary, posing more fundamental challenges to underlying principles. Actors who question

50. KeOHANE \& NyE, supra note 46, at 55; see also Brett Frischmann, A Dynamic Institutional Theory of International Law, 51 BUFF. L. REV. 679 (2003) (emphasizing the importance of comparative analysis of institutions for understanding the different evolution of the trade and environment regimes).

51. This definition describes only one facet of a broader phenomenon in which state and nonstate actors strategically move from one lawmaking or dispute settlement venue to another. For example, a powerful state unable to realize its objectives through treaty negotiations may shift to domestic lawmaking and enact rules with extraterritorial effects that have much of the same effect. Similarly, states may operate in multiple domestic and international fora, moving back and forth between venues seriatim or pursuing parallel lawmaking agendas simultaneously. See Graeme B. Dinwoodie, The Integration of Domestic and International Intellectual Property Lawmaking, 23 COLUM.-VLA J.L. \& ARTS 307 (2000). Private parties often engage in similar behavior, strategically choosing to litigate their claims in one of several available adjudicatory fora. See Laurence R. Helfer, Forum Shopping for Human Rights, 148 U. PA. L. REV. 285, 290 (1999) (analyzing different types of forum shopping among international human rights tribunals).

52. David J. Puchala \& Raymond F. Hopkins, International Regimes: Lessons from Inductive Analysis, in INTERNATIONAL REGIMES, supra note 24, at 61, 66.

53. Id.

54. See John Braithwaite \& Peter Drahos, Global Business Regulation 564-77 (2000) (describing recent examples of "forum shifting and contests of principles"). According to the authors, forum shifting "encompasses three kinds of strategies-moving an agenda from one organization to another, abandoning an organization, and pursuing the same agenda in more than one organization." Id. at 564 . 
the economic and social benefits of granting intellectual property rights to foreign creators and inventors are asserting norms that fall into this latter category. ${ }^{55}$

Once actors decide to contest existing legal prescriptions, critical questions of venue arise. States and NGOs can offer proposals within the same regime that generated the reigning legal standards. But this approach may incite resistance from actors who benefit from the status quo, particularly when more radical reforms are at issue. As a result, homegrown efforts to change existing principles, norms, and rules may be less effective than shifting to a different regime. ${ }^{56}$

Choosing among available alternative fora (or deciding to establish an entirely new forum) implicates the institutional component of regimes and suggests the need for a comparative analysis. In some regimes, powerful countries dominate negotiating agendas and shape outcomes to suit their interests. In others, hegemons may be absent or may play a more limited role, creating opportunities for weaker states. ${ }^{57}$ In addition to disparities in state membership and influence, international regimes differ in their lawmaking methods (for example, hard law treaty negotiations or soft law standard setting), their mechanisms for monitoring and dispute settlement (such as requiring states to submit disputes to an international tribunal as compared to voluntary reporting procedures), their institutional cultures (such as granting officials of intergovernmental organizations greater or lesser authority to advocate particular goals), and their permeability to outside influences (as exemplified by organizations in which only states have standing versus those in which NGOs may participate). These varied institutional characteristics provide states and non-state actors with an abundance of venues in which to generate counterregime norms. ${ }^{58}$

55. This distinction between evolutionary and revolutionary changes to an international regime roughly parallels Stephen Krasner's distinction between changes within regimes and changes to a regime itself. See Krasner, Structural Causes, supra note 24, at 3-5. Modification of rules and decision-making procedures, Krasner argues, are changes within regimes. These changes often occur in response to new external conditions, but they do not reflect fundamental shifts in values. By contrast, changes in principles and norms are changes to a regime itself. They indicate that basic regime tenets are under challenge, often because one group of states is seeking to replace them with competing tenets. Differentiating between these two types of regime change is often difficult, however, both because of the difficulty of making sharp distinctions between principles, norms, and rules, and because states often adopt divergent interpretations of change that serve their strategic interests. $I d$. at 4 (noting that industrialized states interpreted special and differential treatment for developing states in GATT as an intra-regime change, whereas developing states viewed it as part of a normative shift to emphasize "redistribution and equity" over nondiscrimination and efficiency).

56. As this discussion suggests, the creation of principles, norms, and rules rarely occurs on a clean slate and is instead contingent on what has occurred in the past. See Oona A. Hathaway, Path Dependence in the Law: The Course and Pattern of Legal Change in a Common Law System, 86 IowA L. REV. 601 (2001) (discussing different path dependence theories). The path dependence of international lawmaking means that regime shifting is often a reactive strategy.

57. Compare infra note 84 (discussing hegemonic power within the WTO and GATT) with note 263 (noting absence of the United States as a party from major human rights, environmental, and PGR treaties).

58. Not all of these venues may be equally effective for states seeking to change the prevailing legal landscape. Where, for example, one regime has especially strong dispute settlement and sanctioning mechanisms, there will be a temptation to incorporate principles, norms, and rules from weaker regimes into the stronger regime to benefit from those mechanisms. This force-which 
Regime shifting also affects the relational aspect of international regimes, in particular the issue area borders that separate one regime from another. During most of the latter half of the twentieth century, these boundaries were well-defined, with each regime governing an issue area that was "'decomposable' from the rest of the system, in the sense that [it] operated without close links to other regimes in other issue-areas." ${ }^{\text {"59 }}$ When regimes have such discrete boundaries, states and NGOs seeking to generate counterregime norms can either shift to another lawmaking venue situated within the same regime (an intra-regime shift), or they can move to a venue located in an entirely different regime (an inter-regime shift). A state that moves negotiations of new free trade obligations from a multilateral treaty to a regional trade pact or to a web of bilateral trade agreements is engaging in intra-regime shifting. ${ }^{60} \mathrm{~A}$ state that introduces rules to protect the global environment into an intergovernmental organization previously devoted to lowering trade barriers is attempting an inter-regime shift. ${ }^{61}$

These examples describe idealized regime shifts. But they illustrate the moves available to states when regimes are discrete and easily disaggregated. Recently, however, the boundaries between regimes have become less rigid as international governance efforts have expanded their reach and become more interdependent. Such interdependence promotes the formation of networks among formerly disparate state, intergovernmental, and non-state actors and linkages among formerly discrete issue areas. The result is a "conglomerate type of regime" ${ }^{\text {"62 }}$ or a "regime complex"63 - a multi-issue, multi-venue mega-

commentators have described using such colorful phrases as "penance envy," José E. Alvarez, The New Treaty Makers, 25 B.C. INT'L \& COMP. L. REV. 213, 226 n.28 (2002), and "regime borrowing," Leebron, supra note 33, at 19-explains proposals to incorporate labor, human rights, and environmental norms into the WTO. See ANDREW T. GUZMAN, TRADE, LABOR, LEGITIMACY (Univ. of Cal. Berkeley School of Law, Public Law and Legal Theory Research Paper No. 116, 2003), at http://ssm.com/abstract=391420; Gregory C. Shaffer, The World Trade Organization Under Challenge: Democracy and the Law and Politics of the WTO's Treatment of Trade and Environment Matters, 25 HARV. ENVTL. L. REv. 1 (2001); Patricia Sterling, The Use of Trade Sanctions as an Enforcement Mechanism for Basic Human Rights: A Proposal for Addition to the World Trade Organization, 11 AM. U. J. INT'L L. \& POL'Y 1 (1996). It also helps to explain why developing countries are seeking to incorporate intellectual property norms generated in the biodiversity, PGR, public health, and human rights regimes into the WTO. See infra Part V.

59. Robert O. Keohane \& Joseph S. Nye, Jr., The Club Model of Multilateral Cooperation and Problems of Democratic Legitimacy, in EFFICIENCY, EQUITY, AND LeGITIMACY: The MulTILATERAL TRAdNG SYSTEM AT THE MiLlenNiUm 264, 266 (Roger B. Porter et al. eds., 2001).

60. This is precisely the sort of shifting currently being advanced by the United States. See Edmund L. Andrews, Singapore and U.S. Near a Trade Deal, N.Y. TIMES, Nov. 20, 2002, at Cl (noting emergence of a "new strategy" by the United States that "increasingly relies on negotiating deals with individual countries and small regions, in part to build support for more ambitious projects, like a 'free trade agreement for the Americas' and a new global trade agreement at the World Trade Organization"); see also Elizabeth Becker, U.S. Begins Talks for Trade Pact with Central Americans, N.Y. TIMES, Jan. 9, 2003, at C1 (discussing regional and bilateral trade agreements between United States and Central and South American countries).

61. See, e.g., Paulette L. Stenzel, Why and How the World Trade Organization Must Promote Environmental Protection, 13 DUKE ENVTL. L. \& POL'Y F. 1, 4 \& n.17 (2002) (discussing proposals to incorporate environmental law concerns into the WTO).

62. Leebron, supra note 33, at 19. See also id. at 10 (describing the "trade regime" as consisting of "not only of the WTO and bilateral and regional agreements and institutions, but also of informal consultative mechanisms and expectations of behavior that occur on a plurilateral or bilateral basis").

63. Kal Raustiala \& David G. Victor, The Regime Complex for Plant Genetic Resources, 58 INT'L ORG. (forthcoming 2004) (manuscript at 7, on file with The Yale Journal of International Law) 
regime in which states and NGOs shift negotiations from one venue to another within the conglomerate, "select[ing] the forum that best suit[s] their interests." $" 64$

Regime shifting serves a cross-pollinating function that facilitates this evolution from decomposable to conglomerate regimes. Where actors move lawmaking initiatives from one discrete regime to another, they often introduce new issues into venues that previously operated within tight subjectspecific parameters. This "issue-area incorporation" spawns new relationships among different actors and institutions, redefines issue area boundaries, and wears away at the distinctions among regimes. ${ }^{65}$ It may also increase competition among intergovernmental organizations and conflicts between competing principles, norms, and rules ${ }^{66}$ - both of which are useful for actors seeking to contest or supplant existing legal prescriptions.

As this discussion makes clear, the term "regime shifting" encompasses a rich variety of moves among international lawmaking fora (both within and among discrete regimes and regime complexes) as well as expansions or shifts of issue area boundaries. So defined, regime shifting is a game that both strong and weak actors can play. On the one hand, a realist theory of international relations suggests that powerful nations are likely to be adroit regime shifters, and the empirical evidence supports this, including in the area of intellectual property rights. ${ }^{67}$ But, contrary to the assertion of some commentators, ${ }^{68}$ weaker states and networks of states and NGOs can also engage in regime shifting, although the specific rationales and the strategies they employ may differ from those of well-resourced nations. ${ }^{69}$

(defining a "regime complex" as "an array of partially overlapping institutions governing a particular issue-area," among which there is no agreed upon hierarchy).

64. Id. at 34.

65. Leebron, supra note 33 , at 18 . This outcome is especially likely where disparities exist between the monitoring and enforcement mechanisms of international regimes, creating "penance envy" and incentives for "regime borrowing." See supra note 58 (discussing these terms).

66. See David D. Caron, The International Whaling Commission and the North Atlantic Marine Mammal Commission: The Institutional Risks of Coercion in Consensual Structures, 89 AM. J. INT'L L. 154, 155 (1995) (describing how states dissatisfied with the International Whaling Commission (IWC) created a new intergovernmental organization--the North Atlantic Marine Mammal Commission-which functioned as "an institutional release mechanism compensating for the IWC's inability to moderate its strong antiwhaling position"); Joel P. Trachtman, Institutional Linkage: Transcending "Trade and . . , , 96 AM. J. INT'L L. 77, 92 (2002) (discussing "the role of interorganizational competition") [hereinafter Trachtman, Institutional Linkage].

67. See BRAITHWAITE \& DRAHOS, supra note 54, at 564-65 (reviewing instances of "forum shifting" in a variety of substantive issue areas and concluding that "only the US has used this strategy with any frequency"). Powerful states are often induced to shift lawmaking agendas to another regime when weaker states band together to deadlock negotiations in an existing regime. This provides part of the explanation for the United States' efforts to move intellectual property lawmaking from WIPO to GATT. See infra Section II.C.

68. According to Braithwaite and Drahos, "forum-shifting is a strategy that only the powerful and well-resourced can use." BRAITHWAITE \& DRAHOS, supra note 54, at 565. Less powerful states, they argue, are limited to reactive strategies, attempting to block unfavorable venue shifting by powerful nations, or, where blocking is impossible, advancing their agendas as best they can in the new forum. Id.

69. As explained in greater detail in Part IV, even relatively weak developing countrieswhen acting as a group and bolstered by the support of sympathetic NGOs and intergovermmental organizations-can undertake a regime shifting strategy. Cf. Leebron, supra note 33, at 12 (arguing that relatively weaker nations can engage in "strategic linkage" by connecting issues in which their power is limited to issues "on which they have a stronger bargaining position"). 
Although the practice of regime shifting is not new, neither for intellectual property nor for other issue areas, ${ }^{70}$ its theoretical and practical consequences for international law and politics have gone largely unnoticed by scholars. In Parts III and IV, I identify and analyze the different rationales motivating developing countries and NGOs to move intellectual property lawmaking into the biodiversity, PGR, public health, and human rights regimes. Here I focus on an earlier instance of regime shifting by powerful nations - the successful effort by the United States and the EC to move intellectual property negotiations from WIPO to the GATT, leading to the adoption of the TRIPs Agreement. ${ }^{71}$ I begin with a discussion of the public choice aspects of regime shifting, identifying the private actors who lobbied their respective governments to incorporate intellectual property rights into the trade regime. The result of this incorporation effort was a marked strengthening of substantive intellectual property standards, enforcement mechanisms, and dispute settlement procedures-a result with significant consequences for developing country governments.

\section{Regime Shifting From WIPO to GATT to TRIPs}

\section{The Public Choice Dimension of Regime Shifting}

International lawyers and international relations theorists often speak of nation states as if they were unitary actors that rationally calculate and then rationally pursue their national interests when interacting with other states.

In fact, post-TRIPs intellectual property regime shifting is not the first time that developing countries have attempted to enhance their bargaining power by shifting lawmaking to a different venue. During the 1960s and 1970s, developing states created the United Nations Conference on Trade and Development (UNCTAD) to address trade and development issues that had been given insufficient attention in the GATT. UNCTAD acted as a "forum organization," helping to articulate and shape state interests and assisting developing country govemments in their negotiations with developed countries in the GATT. Javed A. ANSARI, THE PolitiCal ECONOMY Of INTERnational ECONOMIC ORGanization 216-17, 224 (1986). During the close of the Tokyo Round of trade talks, the UNCTAD Secretariat drafted studies and proposals that shaped negotiating strategies. The result was "a final package that gave developing countries a free ride on many agreements" and enshrined a principle of special and differential treatment that commentators at the time viewed as weakening the trade regime. Richard $\mathrm{H}$. Steinberg, In the Shadow of Law or Power? Consensus-Based Bargaining and Outcomes in the GATT/WTO, 56 INT'L ORG. 339, 357 n.95, 359 (2002) (discussing effective influence of UNCTAD on developing countries' negotiating strategies during the Tokyo Round); Jock A. Finlayson \& Mark W. Zacher, The GATT and the Regulation of Trade Barriers: Regime Dynamics and Functions, in INTERNATIONAL REGIMES, supra note 24, at 273, 296 ("The Tokyo Round appears to have enshrined special treatment [for developing states] as a central norm of the regime, although the effect on trade bargaining is unclear."); Krasner, Structural Causes, supra note 24, at 5 ("Special and differential treatment for developing countries is an indication that the liberal [trade] regime has weakened.").

70. Indeed, an even earlier instance of intellectual property regime shifting than those discussed in this Article occurred in the 1950s when the United States, unwilling to conform its domestic copyright laws to the requirements of the Berne Convention but under pressure to protect foreign authors, supported the creation of an alternate treaty system - the UNESCO-sponsored Universal Copyright Convention (UCC). See Barbara A. Ringer, The Role of the United States in International Copyright-Past, Present, and Future, 56 Geo. L.J. 1050, 1060-64 (1968) (discussing the history of the UCC and its ratification by the United States). I am indebted to Ruth Okediji for this insight.

71. For detailed discussions of this regime shifting strategy and its consequences, see generally GATT OR WIPO? NEW Ways IN THE INTERnational Protection OF INTEllectual PROPERTY (Friedrich-Karl Beier \& Gerhard Schricker eds., 1989) [hereinafter GATT OR WIPO?]; Susan K. Seli, POWER and Ideas: North-South Politics of InTEllectual Property and ANTITRUST (1998) [hereinafter SELL, POWER AND IDEAS]. 
Although this simplifying assumption can be a useful way to model many forms of inter-state behavior, ${ }^{72}$ the reality of international cooperation is far more complex. States are not unitary but are composed of a diverse array of governmental institutions populated by officials who pursue their own agendas and draw legitimacy from their relationship to domestic constituencies. Private interest groups and members of civil society are also critical players, aggregating individual preferences and lobbying the various branches of government to adopt the policies they favor. ${ }^{73}$

Disaggregating states into transparent entities composed of distinct governmental and nongovernmental actors makes possible a public choice analysis of international lawmaking and regime shifting in particular. ${ }^{74}$ Public choice theory views government decisions as the product of interest group politics. It argues that concentrated interest groups with high individual stakes will devote significant resources to lobbying government officials if doing so allows those groups to acquire advantages through regulation that would be unavailable in the market. Because such interest groups face lower informational and organizational costs than more diffusely organized voters or consumers, they tend to be more successful in mobilizing resources and influencing legislative outcomes. ${ }^{75}$

Viewing international lawmaking through the lens of public choice helps to identify the specific governmental and private actors who motivate states to engage in regime shifting. The incorporation of intellectual property rights into the WTO, manifested in the move from WIPO to GATT to TRIPs, was nominally carried out by trade officials from the United States and the EC. But, as I explain in greater detail below, it was a strategy adopted at the urging of American and European intellectual property industries, who were dissatisfied with status quo approaches to intellectual property lawmaking and foresaw considerable advantages from shifting negotiations into the trade regime.

72. See Andrew T. Guzman, A Compliance-Based Theory of International Law, 90 CAL. L. REV. 1823, 1841 n.73 (2002) (noting that the "standard assumptions about states" in models of international relations are that "they are rational, they act in their own self-interest, and they are aware of the impact of international law on behavior").

73. See Anne-Marie Slaughter, $A$ Liberal Theory of International Law, 94 AM. SoC'Y INT'L L. PROC. 240, 241 (2000) (describing insights of liberal international relations theory as including its bottom-up view, its linking of international and domestic spheres, its rendering of state-society relations as transparent, and its transformation of states into governments).

74. Paul Stephan is the leading proponent of a public choice analysis of international institutions. See, e.g., Paul B. Stephan, Accountability and International Lawmaking: Rules, Rents and Legitimacy, 17 Nw. J. INT'L L. \& BuS. 681 (1996-1997) [hereinafter Stephan, Accountability and International Lawmaking]; Paul B. Stephan, The Futility of Unification and Harmonization in International Commercial Law, 39 VA. J. INT'L L. 743 (1999). See also Jeffrey L. Dunoff \& Joel P. Trachtman, The Law and Economics of Humanitarian Law Violations in Internal Conflict, 93 AM. J. INT'L L. 394, 396 (1999) ("Public choice can be used to analyze treaties, as well as the creation and interaction of international institutions.").

75. See, e.g., Dunoff \& Trachtman, supra note 74, at 396; Andrew T. Guzman, Choice of Law: New Foundations, 90 GEO. L.J. 883, 903 (2002). 


\section{Motivations for the Shift From WIPO to GATT}

Two factors motivated the United States and the EC, in response to pressures from their respective intellectual property industries, to shift intellectual property lawmaking from WIPO to GATT. The first related to dissatisfaction with treaty negotiations hosted by WIPO. The second focused on institutional features of the GATT that facilitated adoption of more stringent intellectual property protection standards that these states favored.

The United States' concerns with WIPO date to the 1970s, when developing countries became increasingly critical of the international patent system. These governments raised their concerns at a WIPO diplomatic conference, held between 1980 and 1984, where they demanded a revision of the patent rules of the Paris Convention ${ }^{76}$ to grant them preferential treatment. The United States strongly opposed any efforts to weaken the treaty and fought developing countries to a standstill. The diplomatic conference ended in deadlock in 1985 without adopting any treaty revisions. ${ }^{77}$

Although successful in fending off attempts to undermine the Paris Convention, the United States came under increasing pressure from its intellectual property industries to improve their competitiveness in foreign markets by combating widespread infringement ${ }^{78}$ and raising standards of protection. ${ }^{79}$ The failed negotiations over patent protection led the United States to conclude that it could not achieve that goal within WIPO. ${ }^{80}$ The government had, however, increased protection standards by linking intellectual property to trade in a series of bilateral consultations with

76. Paris Convention for the Protection of Industrial Property, Mar. 20, 1883 (as revised at Stockholm, July 14, 1967), 21 U.S.T. 1583, 828 U.N.T.S. 305 [hereinafter Paris Convention].

77. For detailed discussions of the Paris Convention diplomatic conference, see SELL, POWER AND IDEAS, supra note 71, at 107-30.

78. See Edgardo Buscaglia \& José-Luis Guerrero-Cusumano, Quantitative Analysis of Counterfeiting Activities in Developing Countries in the Pre-GATT Period, 35 JURIMETRICS J. 221, 22531 (1995) (reporting results of empirical case study measuring the infringement of patented and copyrighted goods and services in developing countries).

79. SELL, POWER AND IDEAS, supra note 71, at 130 (stating that after the failed Paris Convention diplomatic conference the "United States radically refined its interests in intellectual property protection under industry-based pressure to stay economically competitive"); Sell, Access to Medicines, supra note 8, at 483-91 (discussing influence of paper by economist Jacques Gorlin that advocated incorporation of intellectual property rules into the trade regime, a position later adopted by twelve American transnational corporations who formed the Intellectual Property Committee); see also Okediji, Cartography, supra note 8, at 67-99 (discussing coalitions formed by intellectual property industries and trade officials who negotiated TRIPs); CEAS CONSULTANTS, supra note 7, at 40 (noting that "the industry lobby groups essentially wrote the TRIPS Agreement, especially the US industry and a narrower group in the EU').

80. See BRAITHWAITE \& DRAHOS, supra note 54, at 566 (noting that negotiations in WIPO followed the one-state-one-vote rule and "so the US could never expect to get its way on intellectual property issues through a voting contest"); Ulrich Joos \& Rainer Moufang, Report on the Second Ringberg-Symposium, in GATT OR WIPO?, supra note 71, at 3, 31 (describing history of the United States' successful efforts to fend off attempts to weaken the Convention, and concluding that "this experience apparently led the U.S. to the conclusion that an improvement of the [Paris Convention] could not be achieved in the present context of the North-South conflict"); Bal Gopal Das, Intellectual Property Dispute, GATT, WIPO: Of Playing by the Game Rules and Rules of the Game, 35 IDEA 149, 158 n.45 (1994) ("Dissatisfaction with WIPO's ineffectiveness as a forum to end the impasse which ensued after the failed Paris Revision Conference, aggravated by the continued intransigence of the Developing countries, motivated the movement away from WIPO to GATT as the negotiating forum."). 
developing countries in the 1980 s. Buoyed by the success of that linkage strategy and at the urging of corporate intellectual property owners, the United States shifted to a multilateral approach. It pressed for the inclusion of intellectual property issues in the 1986 negotiating mandate for the Uruguay Round of GATT negotiations leading to the creation of the WTO. ${ }^{81}$ The EC later endorsed this approach and offered its own proposal for negotiations on trade-related aspects of intellectual property rights. ${ }^{82}$

Three institutional features of the GATT/WTO made it a superior venue for the United States and the EC to negotiate intellectual property protection standards. ${ }^{83}$ First, these states enjoy significant negotiating leverage in the GATT/WTO. As the region and the nation with the largest domestic markets, the EC and the United States have the most power to shape trade bargains according to their interests by promising to open (or threatening to close) their markets to foreign goods. ${ }^{84}$ In addition, GATT/WTO negotiations operate on the principle of consensus, which the United States and the EC have used strategically to force disclosure of weaker states' preferences, block the advancement of proposals those states favored, and advance their own initiatives. ${ }^{85}$ Consensus also masks the real power dynamics at work in the GATT/WTO, legitimizing final treaty bargains as the product of unanimous consent among equal sovereigns. ${ }^{86}$

Second, the ability to link intellectual property protection to other issue areas within the GATT/WTO expanded the zone of agreement among states with widely divergent interests. The instrumental explanation for why states whose laws contained only weak protections for foreign rights holders would agree to stronger intellectual property standards is precisely the allure of this

81. See GATT Ministerial Declaration on the Uruguay Round of Multilateral Trade Negotiations, Sept. 20, 1986, 25 I.L.M. 1623 (1986); United States Proposal for Negotiations on TradeRelated Aspects of Intellectual Property Rights, GATT Doc. MTN.GNG/NG11/W/14 (Oct. 20, 1987), reprinted in GATT OR WIPO?, supra note 71, at 179-86; see also SELL, POWER AND IDEAS, supra note 71 , at 132-38 (discussing United States' linking of trade and intellectual property protection in bilateral negotiations and the evolution of a multilateral linkage strategy within GATT supported by American intellectual property industries).

82. Guidelines Proposed by the European Community for the Negotiations on Trade-Related Aspects of Intellectual Property Rights, GATT Doc. MTN.GNG/NG1 1/W/16 (Nov. 20, 1987), reprinted in GATT OR WIPO?, supra note 71, at 203-10.

83. See, e.g., SELL, POWER AND IDEAS, supra note 71 , at 132 (identifying advantages for the United States of negotiations in GATT); Joos \& Moufang, supra note 80, at 25 (discussing advantages of negotiating intellectual property issues in GATT).

84. See Steinberg, supra note 69, at 341 (noting that "the EC and the United States have dominated bargaining and outcomes at the GATT/WTO from its early years"); Richard H. Steinberg, Trade-Environment Negotiations in the EU, NAFTA, and WTO: Regional Trajectories of Rule Development, 91 AM. J. INT'L L. 231, 232 (1997) ("richer countries tend to be more powerful in trade negotiations than poorer countries since, in the international trade context, 'power' may be seen as a function of relative market size").

85. BRAITHWAITE \& DRAHOS, supra note 54, at 570 ("One reason why the US has been prepared to shift its agenda into WTO is that consensus offers it a tool of domination."); Steinberg, supra note 69, at 350-67 (arguing that a consensus to launch new trade rounds of trade talks is achieved by including all states' initiatives in negotiating mandates, but that rounds are closed through powerbased bargaining in which the proposals of the United States and the EC are ultimately adopted).

86. See Steinberg, supra note 69 , at 365 (noting that "the GATT/WTO decision-making rules have allowed adherence to both the instrumental reality of asymmetrical power and the logic of appropriateness of sovereign equality"). 
global "package deal." ${ }^{87}$ Developing nations agreed to include intellectual property within the newly created WTO in exchange for securing access to the markets of industrialized states for their agricultural products, textiles, and other goods. According to this explanation, moving negotiations to the WTO made it possible for the United States and the EC to achieve broader and deeper agreements on intellectual property protection than would have been possible had negotiations been confined to WIPO. ${ }^{88}$

Third, the GATT's dispute settlement system was perceived to be far more effective than the mechanisms for reviewing states' compliance with WIPO-based conventions-mechanisms that were cumbersome in theory and never utilized in practice. ${ }^{89}$ Although the GATT system was far from perfect-losing parties could, for example, block the adoption of unfavorable panel reports-states were not hesitant to invoke the dispute settlement process. And the very existence of an authoritative decision endorsing one side's arguments created pressure on the losing state to modify its laws. Moreover, one of the major achievements of the Uruguay Round was a restructuring of dispute settlement rules to make decisions binding on all states and to authorize the use of retaliatory sanctions by prevailing states if their opponents did not alter WTO-incompatible national laws or provide compensation. $^{90}$

These three features of the trade regime explain why the GATT/WTO would be attractive to industrialized countries as a forum for intellectual property lawmaking. But they do not explain why the United States-so often suspicious of multilateralism - would cede authority to an intergovernmental organization with significant independent enforcement powers. The answer to this question is that such adherence was in the United States' interests. Even if developing countries were prepared to acquiesce in efforts to include intellectual property rights and other new regulatory issues within a more powerful trade regime, they were unwilling to do so unless the United States abandoned or markedly reduced the policy of imposing unilateral trade sanctions that it had adopted in the $1980 \mathrm{~s}^{91}$ Seen from this perspective, the

87. Petersmann, supra note 3 , at 442.

88. See Leebron, supra note 33, at 12-13.

89. Frank Emmert, Intellectual Property in the Uruguay Round-Negotiating Strategies of the Western Industrialized Countries, 11 MICH. J. INT'L L. 1317, 1343 (1989) (describing dispute settlement provisions in Berne and Paris Conventions as "effectively worthless"); see also Monique L. Cordray, GATT v. WIPO, 76 J. PAT. \& TRADEMARK OFF. SOC'Y 121, 131-32 (1994) (critiquing dispute settlement provisions of WIPO-based intellectual property conventions).

90. See Laurence R. Helfer, Adjudicating Copyright Claims Under the TRIPs Agreement: The Case for a European Human Rights Analogy, 39 HARV. INT'L L.J. 357, 383-85 (1998) (collecting authorities discussing the importance to the WTO dispute settlement system of the prevailing state's ability to impose trade sanctions on the losing state). But see Frischmann, supra note 50 , at 778 (emphasizing that the WTO Dispute Settlement Body may impose only "prospective trade measures intended to offset only the prospective harm imposed on the injured party" and that "[n]either compensation for past harm nor punitive sanctions are permitted") (emphasis omitted); Ruth Okediji, Rules of Power in an Age of Law: Process Opportunism and TRIPs Dispute Settlement, in HANDBOOK OF INTERNATIONAL TRADE LAW (Kwan Choi \& James Hartigan eds.) (forthcoming 2004) (asserting that WTO dispute settlement system is structured as a signaling game that encourage the parties to "opt out of the formal process and settle the dispute informally").

91. See G. Richard Shell, Trade Legalism and International Relations Theory: An Analysis of the World Trade Organization, 44 DUKE L.J. 829, 843-44 (1995) ("The statutory vehicles for unilateral 
United States' decision to bind itself to hard-edged multilateralism was a necessary part of the bargain required to close the Uruguay Round with a package of treaty commitments highly favorable to U.S. interests. ${ }^{92}$

By the spring of 1994, the United States and the EC had achieved their objective of incorporating internationally enforceable intellectual property norms into the world trading system. The newly created WTO included a detailed and comprehensive Agreement on Trade-Related Aspects of Intellectual Property Rights (TRIPs) to which all WTO members were required to adhere. The next section describes the consequences for developing countries of this shift in intellectual property lawmaking from WIPO to TRIPs.

\section{The Consequences of TRIPs for Developing Countries}

As has been widely discussed by commentators, TRIPs revolutionized international intellectual property law. It enhanced the substantive rules found in preexisting agreements negotiated within WIPO and included them within a single treaty that imposed a comprehensive set of intellectual property protection standards. The obligation to provide such protection extended to the entire WTO membership, including many developing states whose previous commitment to intellectual property protection was nonexistent or at best equivocal. $^{93}$

Unlike prior intellectual property agreements, compliance with TRIPs could not be shirked through partial implementation or slow and cumbersome dispute settlement procedures. For foreign intellectual property owners, TRIPs promised meaningful enforcement rights within national legal systems, ${ }^{94}$ a promise that required states to adopt extensive changes to domestic judicial and administrative systems. For states dissatisfied by the weak intellectual property laws of their fellow WTO members, TRIPs promised high levels of treaty adherence through two new institutions: the Council for TRIPs (TRIPs Council), which conducts transparent reviews of national implementation measures and provides members with a forum for consultations on compliance issues; and a Dispute Settlement Body with the power to sanction treaty violations. ${ }^{95}$ Faced with the prospect of robust review and enforcement of intellectual property rules, WTO members not surprisingly devoted significant

action were section 301, 'Super 301,' and 'Special 301,' all of which are parts of the Trade Act of 1974, as amended.") (footnotes omitted); see also Jagdish Bhagwati, Aggressive Unilateralism: An Overview, in Aggressive Unilateralism: AMERICA's 301 TRADE POLICY AND THE WORLd Trading SYSTEM 1 (Jagdish Bhagwati \& Hugh T. Patrick eds., 1990) (discussing private interest groups pressing for imposition of unilateral trade sanctions by the United States).

92. See Shell, supra note 91, at $844-45$ (explaining how the "use of section 301 as a unilateral trade weapon against foreign governments and industries outside the legal framework of the GATT upset many U.S. trading partners and became a major issue in the Uruguay Round") (footnotes omitted).

93. For a review of the changes TRIPs wrought, see J.H. Reichman, Universal Minimum Standards of Intellectual Property Protection Under the TRIPs Component of the WTO Agreement, 29 INT'L LAW 345 (1995).

94. TRIPs, supra note 1, arts. 41-46, 33 I.L.M. at 99-101 (establishing procedures for domestic enforcement of intellectual property rights).

95. Id. art. 64, 33 I.L.M. at 107 (linking TRIPs to WTO's Dispute Settlement Understanding (DSU)), art. 68, 33 I.L.M. at 108 (creating Council for TRIPs). But see Okediji, supra note 90 (arguing that the DSU is structured to encourage settlement rather than the imposition of sanctions). 
time and resources to transposing TRIPs commitments into their national legal systems. $^{96}$

TRIPs's drafters recognized that overhauling national intellectual property laws was likely to be difficult. Thus they gave least developed and developing states and countries with economies in transition additional time to comply with the treaty. ${ }^{97}$ But with the end of the five-year transition period in 2000 looming large, and implementation proving increasingly slow, costly, and a source of domestic opposition, TRIPs had begun to look increasingly problematic for many developing states. ${ }^{98}$ The United States and the EC added to this perception by pressuring developing countries to sign "TRIPs-plus" bilateral agreements. These agreements contained intellectual property protection standards that exceeded those found in TRIPs or required developing countries to implement their treaty obligations before the end of TRIPs transition periods. ${ }^{99}$ For all of these reasons, the TRIPs implementation process did not generate the consensus in favor of higher intellectual property protection standards that some observers had predicted. ${ }^{100}$ Instead, it fostered a growing belief, shared by many developing countries, NGOs, and commentators, that TRIPs was a coerced agreement that should be resisted rather than embraced. ${ }^{101}$

96. See Communication from Australia-Review of the Implementation of the Agreement Under Article 71.1, at 2, WTO Doc. IP/C/W/210 (Oct. 3, 2000) ("[M]any WTO Members have undertaken extensive legislative and administrative action to give effect to their obligations under the Agreement. Implementation has been a complex and diverse process in many jurisdictions ....").

97. TRIPs, supra note 1, arts. 65-66, 33 I.L.M. at 107-08 (specifying transition periods for different categories of WTO members).

98. See Reichman, supra note 93 , at 450 ("[T]he bulk of the developing countries appear behind schedule in implementing the TRIPs Agreement. Many will not be ready by January 1,2000 and they are in an increasingly angry and resentful frame of mind.") (footnote omitted); $i d$. at 451 (noting the "growing perception that the benefits of higher intellectual property protection may be very unevenly distributed" although "all the developing countries must bear" significant transaction costs).

99. See supra note 10.

100. See J.H. Reichman \& David Lange, Bargaining Around the TRIPs Agreement: The Case for Ongoing Public-Private Initiatives to Facilitate Worldwide Intellectual Property Transactions, 9 DUKE J. COMP. \& INT'L L. 11, 13 (1998) (questioning the "widespread belief that, once the transitional deadlines begin to expire, the developing countries will succumb to an evolving high-protectionist agenda" for intellectual property lawmaking).

101. See, e.g., Declaration of the Group of 77 and China on the Fourth WTO Ministerial Conference at Doha, Qatar (Oct. 22, 2001), http://www.g77.org/Docs/Doha.htm (noting "with great concern that the benefits of the existing multilateral trading system continue to elude developing countries" and characterizing Uruguay Round Agreements, including TRIPs, as containing "inherent asymmetries and imbalances"); Inge Govaere \& Paul Demaret, The TRIPs Agreement: A Response to Global Regulatory Competition or an Exercise in Global Regulatory Coercion?, in REGULATORY COMPETITION AND ECONOMIC INTEGRATION: COMPARATIVE PERSPECTIVES 364, 369 (Daniel C. Esty \& Damien Geradin eds., 2001) (noting that industrialized countries "did not hesitate to coerce the developing countries into accepting their terms" regarding the need for intellectual property protection); Lohr, supra note 11 (quoting statement by Professor Keith Maskus that "[TRIPs] was a matter of powerful companies with intellectual property concerns essentially dictating trade policy"); South Centre, supra note 7 (articulating demand by 130-member consortium of NGOs for "a fundamental rethinking of TRIPS" in the WTO); Martin Khor \& Chakravarthi Raghavan, Third World Network, WTO Secretariat Explains Its TRIPS 'Negotiating History,' at http://www.twnside.org.sg/title/explains.htm (June 11, 2001) ("The 'history' of the TRIPS negotiations . . . shows that it is a case of an agreement negotiated and concluded under coercion, and hence illegitimate."). 


\section{The Continuing Importance of WIPO}

The negotiation of the TRIPs Agreement marked a watershed moment for the expansion and enforcement of intellectual property protection standards. However, the WTO did not supplant WIPO as the principal intergovernmental organization devoted to intellectual property lawmaking. TRIPs itself implicitly acknowledges the continuing importance of WIPO as a forum for negotiating treaties, particularly those embodying "higher levels of protection of intellectual property rights." ${ }^{102}$ In addition, a 1995 agreement between WIPO and the WTO requires each organization to provide technical and legal assistance to developing countries, delegates to WIPO certain administrative functions in TRIPs, and enhances information sharing about national intellectual property laws. ${ }^{103}$

Seen from this perspective, the shift from WIPO to GATT to TRIPs was not intended to eclipse WIPO. Rather, it established a new venue for traderelated intellectual property lawmaking, in effect creating a bimodal intellectual property regime within which the two organizations shared authority according to their respective areas of expertise. Whereas the WTO emphasized implementation, enforcement, and dispute settlement, WIPO focused on generating new forms of intellectual property protection, administering existing intellectual property agreements, and providing technical assistance to developing countries.

The emergence of this two-track system has facilitated the growth of intellectual property protection standards. In the few short years since TRIPs was adopted, WIPO and its member states have been exceptionally active in negotiating new treaties ${ }^{105}$ and in undertaking an ambitious program of soft

102. See TRIPs, supra note 1, art. 71(2), 33 1.L.M. at 110 (discussing streamlined procedures for TRIPs amendments "merely serving the purpose of adjusting to higher levels of protection of intellectual property rights achieved, and in force, in other multilateral agreements and accepted under those agreements by all Members of the WTO').

103. Agreement Between the World Intellectual Property Organization and the World Trade Organization, Dec. 22, 1995, art. 3, 35 I.L.M. 754 (implementing Article 6ter of the Paris Convention for purposes of TRIPs); id. art. 4, 35 I.L.M. at 758-59 (legal-technical assistance to and technical cooperation with developing countries); id. arts. 2(3) \& 2(4), 35 I.L.M. at 756-57 (information sharing).

104. Commentators have discussed how intellectual property lawmaking competencies might be shared between the WTO and WIPO. Frederick Abbott, for example, has proposed a division of lawmaking along functional lines. He argues that "the primary role of the WTO should be to maintain the competitive balance in trade among WTO Members as foreseen in the TRIPS Agreement." WIPO, by contrast, should aim to "promote technological development, particularly in developing countries, to provide a forum for the negotiation of new multilateral IPRs rules (in coordination with the TRIPS Council), and to administer multilateral IPR conventions as at present." Abbott, Future of TRIPs, supra note 43, at 678; see also Frederick M. Abbott, Distributed Governance at the WTO-WIPO: An Evolving Model for Open-Architecture Integrated Governance, 3 J. INT'L ECON. L. 63, 70 (2000) (asserting that WIPO and WTO have "entered into a symbiotic relationship that takes advantage of the strengths of each of them"). Michael Ryan emphasizes similar concerns, distinguishing between the "functionspecific" lawmaking in WIPO and the "linkage-bargain" lawmaking in the GATT and WTO. Ryan, supra note 43, at 541. This division does not, of course, preclude the WTO from conducting its own negotiations on intellectual property issues, particularly in cases where agreement can be facilitated by "cross-concessions in other fields that the WIPO forum cannot provide." Abbott, Future of TRIPS, supra note 43 , at 679 .

105. In December 1996, for example, WIPO hosted a major diplomatic conference that adopted two new treaties relating to the Internet. See WIPO Copyright Treaty, Dec. 20, 1996, 36 I.L.M. 65; WIPO Performances and Phonograms Treaty, Dec. 20, 1996, 36 I.L.M. 76. WIPO's efforts in the area of 
lawmaking. ${ }^{106}$ These activities have not unambiguously favored either industrialized states or developing countries. Although some initiatives in WIPO do appear to advance the interests of industrialized states, ${ }^{107}$ developing countries retain considerable influence within the organization to shape treaty negotiations and influence soft law initiatives. ${ }^{108}$ Equally as important, WIPO's increased output has started to create a normative feedback loop in the WTO, influencing both TRIPs dispute settlement ${ }^{109}$ and member states' proposals to amend or supplement TRIPs. ${ }^{110}$ WIPO thus continues to function as a critically important venue for intellectual property lawmaking by all of its member states in a post-TRIPs environment.

patents, trademarks, databases, and audiovisual works have been equally impressive, even if members have not always reached agreement on new treaty texts. See Graeme B. Dinwoodie, The Architecture of the International Intellectual Property System, 77 CHI.-KENT. L. REv. 993, 1005 (2002) (noting that "the sudden emergence of the WTO as part of the international intellectual property lawmaking process seemed to energize WIPO, resulting in the conclusion of several new treaties in copyright, patent and trademark law") (footnotes omitted); WIPO Committee Takes Up Proposals on Treaty for Protection of Broadcasters' Rights, 4 Computer Tech. L. Rep. (BNA), No. 13, at 278 (July 4, 2003) (discussing proposals for treaties to protect broadcasters' rights and databases being discussed by WIPO Standing Committee on Copyright and Related Rights).

106. See Assemblies of the Member States of WIPO, Joint Resolution Concerning Provisions on the Protection of Well-Known Marks, Thirty-Fourth Series of Meetings, Sept. 1999, at 3, para. 9, WIPO Doc. No. A/34/13 (Aug. 4, 1999) ("[T]his creates no legal obligation for any country, but following such a recommendation would produce practical benefits."), http://www.wipo.int/eng/ document/govbody/wo_gb_ab/pdf/a34_13.pdf; see also Edward Kwakwa, Some Comments on Rulemaking at the World Intellectual Property Organization, 12 DUKE J. COMP. \& INT'L L. 179, 192 (2002) (discussing resolutions and recommendations that comprise 'the new 'soft law initiative' at WIPO").

107. See J.H. Reichman, Enforcing the Enforcement Procedures of the TRIPS Agreement, 37 VA. J. INT'L L. 335, 354 (1997) ("Prior to the Uruguay Round, WIPO lost credit with the industrialized countries because of its scrupulous concern for the interests of developing countries . . . Since the Uruguay Round, WIPO is seen as the cowed and altogether accommodating servant of dominant special interests in the United States and the European Union .....); GRAIN, WIPO Moves Toward "World" Patent System, http://www.grain.org/publications/wipo-patent-2002-en.cfm (July 2002) [hereinafter GRAIN, World Patent System] (stating that the negotiation of the Substantive Patent Law Treaty "is largely a debate between the US and Europe").

108. See Pamela Samuelson, The U.S. Digital Agenda at WIPO, 37 VA. J. INT'L L. 369, 388-90 \& 388 n. 108 (1997) (discussing influence of African bloc of states at diplomatic conference that adopted the WIPO Copyright Treaty); see also Marney L. Cheek, The Limits of Informal Regulatory Cooperation in International Affairs: A Review of the Global Intellectual Property Regime, 33 GEo. WASH. INT'L L. REV. 277, 314-15 (2001) (stating that WIPO is "sponsoring regional caucus meetings to foster consensus-building among developing countries" to "give developing countries more leverage as the industrialized countries continue to change WIPO's traditional negotiating structure"). For a discussion of developing countries' influence in WIPO relating to genetic resources and traditional knowledge, see infra Sections V.C \& VI.C.

109. See WTO Dispute Panel Report on United States-Section 110(5) of the U.S. Copyright Act, para. 6.70, WTO Doc. WT/DS160/R (June 15, 2000) [hereinafter United States-Section 110(5) Dispute Panel Report] (stating that when interpreting the provisions of the TRIPs Agreement and the Berne Convention, it is appropriate to "seek contextual guidance" in the WIPO Copyright Treaty so as to "develop[] interpretations that avoid conflicts" within the "overall framework for multilateral copyright protection"); Neil W. Netanel, The Next Round: The Impact of the WIPO Copyright Treaty on TRIPS Dispute Settlement, 37 VA. J. INT'L L. 441, 488-96 (1997) (predicting influence of WIPO Copyright Treaty and its Agreed Statement on the adjudication of digital copyright issues in TRIPs dispute settlement cases).

110. For a discussion of such proposals, see infra Sections V.A \& B. 


\section{NEW INTELLECTUAL PROPERTY LAWMAKING IN FOUR INTERNATIONAL REGIMES}

In addition to enhancing intellectual property protection standards and spurring developments within WIPO, the negotiation of the TRIPs Agreement had another important although less well-known effect: it created increased tensions between intellectual property protection standards and the principles, norms, and rules of other international regimes. These tensions had both substantive and procedural dimensions. Substantively, TRIPs required governments to grant intellectual property rights in fields-such as genetic resources, pharmaceuticals, and plant varieties - that in other regimes had been placed outside of private ownership on moral or cultural grounds. ${ }^{111}$ Procedurally, tensions were created by TRIPs's more stringent compliance mechanisms as compared to those of treaty systems outside of the WTO. This created an imbalance whereby compliance with the principles, norms, and rules of another regime could be subordinated to compliance with TRIPs in areas where the two regimes overlapped. These substantive and procedural tensions-which were enhanced by the unsettled and often problematic conflicts rules of public international law ${ }^{112}$-created incentives for new forms of intellectual property lawmaking in other issue areas.

This Part charts the rise of such lawmaking, focusing on four different international regimes-biodiversity, plant genetic resources for food and agriculture (PGRs), public health, and human rights. Intellectual property rights are relevant to each of the issue areas that comprise these regimes. But prior to the negotiation of TRIPs they had received only limited attention in the biodiversity and PGRs regimes and virtually no attention in the public health and human rights regimes. In the wake of TRIPs, however, developing nations, aided by NGOs and (less frequently) by officials of intergovernmental organizations, have adopted a strategy of regime shifting to move intellectual property lawmaking into fora where it was only nascent and to raise intellectual property issues for the first time in other venues. This strategy has resulted in the drafting of new treaties; the reinterpretation of existing agreements, and the creation of new nonbinding declarations, guidelines, and recommendations. Many of these developments criticize the

111. See COMMISSION ON IPRS, supra note 6, at 59 (noting objections "to the patenting of life forms on ethical grounds" based on the belief that "private ownership of substances created by nature is wrong, and inimical to cultural values in different parts of the world"); Sean D. Murphy, Biotechnology and International Law, 42 HARV. INT'L L.J. 47, 65 (2001) (noting some developing states' "ethical or moral belief" that life forms "were considered special and different and not reducible to property rights that might be possessed by some and denied to others"); see also Thammasat Resolution, Dec. 5, 1997, http://web.greens.org/s-r/16/16-13.html (nonbinding resolution of 45 representatives of indigenous, peasant, non-governmental, academic, and governmental organizations from 19 countries opposing TRIPs's privatization of biodiversity, life forms, and traditional knowledge).

112. See Laurence R. Helfer, Constitutional Analogies in the International Legal System, 37 LOY. L.A. L. REV. (forthcoming 2004) (manuscript at 14-18, on file with The Yale Journal of Intemational Law) (analyzing "nomative and institutional hierarchies" in international law and asserting that rules for resolving treaty conflicts "have engendered confusion rather than certainty"). For an extended discussion, see JOOST PAUWELYN, CONFlict OF NORMS IN PUBLIC INTERNATIONAL LAW: How WTO LAW RELATES TO OTHER RULES OF INTERNATIONAL LAW (2003). 
TRIPs Agreement (both for what it includes and what it excludes) as well as other intellectual property protection standards.

For each of the four regimes discussed below, I describe the organizations within which hard and soft lawmaking is occurring as well as the state and nonstate actors who are advancing an intellectual property agenda in those venues. I also identify the core principles, norms, and rules of each regime and their relationship to intellectual property protection. I then explain how actors in each regime responded to TRIPs by creating new principles, norms, and rules to achieve regime objectives that are (to greater or lesser degrees) in tension with existing intellectual property rights. The responses in each regime differed, however, ranging from acceptance (biodiversity) to tolerance (PGRs) to skepticism (public health) to antagonism (human rights). A table at the end of this Part summarizes these differences.

\section{A. Biodiversity}

The evolution of principles, norms, and rules for preserving the world's biological diversity has been shaped by contestations over intellectual property protection. The biodiversity regime's foundational agreement-the Convention on Biological Diversity (CBD) ${ }^{113}$ - protects intellectual property rights as part of a package of treaty commitments that mediate competing claims of industrialized and developing countries. In negotiations leading to the CBD's adoption in 1992, biodiversity-rich but biotechnology-poor developing countries sought financial benefits and technology transfers as incentives to conserve rather than exploit the genetic resources within their borders. Biodiversity-poor but biotechnology-rich industrialized states, by contrast, sought to minimize benefits and transfers while maximizing access to those resources. ${ }^{114}$ The CBD's recognition of intellectual property rights facilitated a compromise between these two positions, allowing industrialized countries to support the transfer of proprietary technologies to developing states as a quid pro quo for access.

Over time, however, the biodiversity regime's approach to intellectual property protection has evolved in ways that could not have been predicted from a simple reading of the CBD's text. The Conference of the Parties (COP) - the convocation of CBD member states that determines how the Convention should be applied and implemented ${ }^{115}$ - has given detailed attention to harmonizing the intellectual property rights in the TRIPs

113. Convention on Biological Diversity, June 5, 1992, U.N. Doc. UNEP/Bio.Div./N7-INC5/4, 31 I.L.M. 818 (1992) [hereinafter CBD]. The CBD was opened for signature in May 1992 and entered into force in December 1993. As of September 2003, 188 states had ratified this agreement. See Secretariat of the Convention on Biological Diversity, Parties to the Convention on Biological Diversity, http://www.biodiv.org/world/parties.asp (last updated Sept. 26, 2003).

114. Patricia lucia Cantuária Marin, Providing Protection for Plant Genetic RESOURCES: PATENTS, SUI GENERIS SYSTEMS, AND BIOPARTNERSHIPS 92 (2002) (discussing competing interests of states that negotiated the CBD).

115. CBD, supra note 113 , art. 23, 31 I.L.M. at $832-33$ (identifying the functions of the Conference of the Parties). 
Agreement with the CBD's objectives. ${ }^{116}$ In particular, developing countries active in the COP, such as China, the G77, India, and several African countries, ${ }^{117}$ together with the support of biodiversity NGOs including Greenpeace, the World Wildlife Fund, the International Union for the Conversation of Nature, and the World Resources Institute, ${ }^{118}$ have expressed concern about the adverse effects of TRIPs on the CBD and have sought to harness intellectual property rules to promote compliance with the Convention. As explained below, the intellectual property-related work undertaken by the COP has focused on two areas: (1) protecting the traditional knowledge of indigenous communities, ${ }^{119}$ and (2) advocating that intellectual property rights applicants should disclose the country of origin of the genetic resources or traditional knowledge which form the basis of their applications.

Strikingly, both of these issues address what many developing governments and NGOs perceive as imbalances in TRIPs. For example, TRIPs does not require protection of indigenous communities' traditional

116. For an overview of the COP's work relating to intellectual property, see The Relationship Between Intellectual Property Rights and the Relevant Provisions of the Agreement on Trade-Related Aspects of Intellectual Property Rights (TRIPs Agreement) and the Convention on Biological Diversity-U.N. Environment Programme, Intersessional Meeting on the Operations of the Convention on Biological Diversity-June 1999, U.N. Doc. UNEP/CBD/ISOC/5 (May 11, 1999). All COP documents are available at http://www.biodiv.org.

117. See, e.g., Report of the First Meeting of the Conference of the Parties to the Convention on Biological Diversity, U.N. Environment Programme, Conference of the Parties to the Convention on Biological Diversity, para. 98, U.N. Doc. UNEP/CBD/COP/1/17 (Feb. 28, 1995) (statement by G77 and China noting their "deep[] concern[] that intellectual property rights deny developing countries access to affordable technology and equitable benefits that accrue from the conservation and sustainable use of biodiversity .... . If the Convention on Biodiversity is to have any meaning beyond superficialities, then the removal of these distortions is crucial."); see also Summary of the Fourth Meeting of the Conference of the Parties to the Convention on Biological Diversity: 4-15 May 1998. EARTH NEGOTIATIONS BULL. (Int'l Inst. for Sustainable Dev., Winnipeg, Can.), May 18, 1998, at 1, 2 (statement by Ethiopia, Mali, and the Seychelles proposing a study of the CBD's relationship with TRIPs); id. at 6 (statement by Tanzania and India stressing that "the Intellectual Property Rights (IPR) regime and the TRIPs agreement of the WTO are detrimental to achieving the objectives of the CBD").

118. Knowledge, Innovations and Practices of Indigenous and Local Communities: Implementation of Article 8(j). Note by the Executive Secretary, U.N. Environment Programme, Conference of the Parties to the Convention on Biological Diversity, para. 94, U.N. Doc. UNEP/CBD/COP/3/19 (Sept. 18, 1996) (quoting statement by the World Wide Fund for Nature on the need for "a positive link between [states'] patent legislation and their legislation governing access to genetic resources"); Farmers' Rights, EARTH Negotiations Bull. (Int'l Inst. for Sustainable Dev., Winnipeg, Can.), June 20 - July 1, 1994, http:/www.iisd.ca/linkages/vol09/0917025e.html (noting support of Greenpeace for a study on the impact of intellectual property rights on the CBD's objectives); see also Kal Raustiala, Domestic Institutions and International Regulatory Cooperation: Comparative Responses to the Convention on Biological Diversity, 49 WORLD POL. 482, 488 (1997) (identifying NGOs active in promoting the CBD).

119. According to a recent study, the terms "traditional knowledge" and "indigenous knowledge" refer to knowledge that is "held collectively (at the community or national level)," has been "used for generations by local communities and [has] contributed to the development of crop varieties, food security and medicines, as well as the emergence and continuation of artistic work in the form of music, handicrafts and artisanship." MAKING GLOBAL TRADE WORK FOR PEOPLE, supra note 6, at 218. Precise definitions of traditional knowledge remain elusive and contested. See Graham Dutfield, TRIPsRelated Aspects of Traditional Knowledge, 33 CASE W. RES. J. INT'L L. 233, 240-41 (2001) (exploring the "definitional dilemmas" of traditional knowledge); see also Michael Blakeney, What Is Traditional Knowledge? Why Should It Be Protected? Who Should Protect It? For Whom?: Understanding the Value Chain-Roundtable on Intellectual Property and Traditional Knowledge, Geneva, Nov. 1-2, 1999, WIPO Doc. WIPO/IPTK/RT/99/3 (Oct. 6, 1999) (analyzing definitional issues). 
knowledge as such. ${ }^{120}$ Nor does the treaty require applicants seeking intellectual property protection to provide information about the origin of genetic resources. ${ }^{121}$ But the forms of intellectual property protection that TRIPs does recognize can be implemented in ways that undermine the CBD's objectives. In particular, nothing in TRIPs requires sharing of financial or technological benefits of biodiversity-related patents and plant innovations with source countries or communities. ${ }^{122}$ Nor does TRIPs require its members to consider unwritten traditional knowledge as a form of "prior art," permitting such knowledge to be patented in its original form. ${ }^{124}$ Developing countries have used the CBD's soft lawmaking activities to redress these imbalances and to reshape intellectual property protection rules within the biodiversity regime to reflect their interests more accurately.

\section{The Convention on Biodiversity's Approach to Intellectual Property}

The CBD is an international framework agreement whose text contains broad objectives rather than tightly constraining rules. The Convention's principal goals are "the conservation of biological diversity, the sustainable use of its components and the fair and equitable sharing of the benefits arising out of the utilization of genetic resources." ${ }^{25}$ The Convention also recognizes the importance of preserving the biodiversity-related knowledge and

120. See Dutfield, supra note 119 , at 236 (noting that "traditional knowledge was a non-issue at the GATT Uruguay Round of trade negotiations"); see also Thomas Cottier, The Protection of Genetic Resources and Traditional Knowledge: Towards More Specific Rights and Obligations in World Trade Law, 1 J. INT'L ECON. L. 555, 567 (1998) (discussing proposals to incorporate traditional knowledge protection into the WTO). TRIPs does, however, require WTO members to protect traditional knowledge to the extent that such knowledge fits within the forms of intellectual property protection that the treaty does recognize (such as copyrights and geographical indications). See Intergovernmental Committee on Intellectual Property and Genetic Resources, Traditional Knowledge and Folklore, Matters Concerning Intellectual Property and Genetic Resources, Traditional Knowledge and Folklore-An Overview, First Session, Geneva, Apr. 30 - May 3, 2001, paras. 72-77, WIPO Doc. WIPO/GRTKF/IC/1/3 (Mar. 16, 2001) [hereinafter IGC Overview]; David R. Downes, How Intellectual Property Could Be a Tool To Protect Traditional Knowledge, 25 COLUM. J. ENVTL. L. 253, 258-78 (2000).

121. See Nuño Pires de Carvalho, Requiring Disclosure of the Origin of Genetic Resources and Prior Informed Consent in Patent Applications Without Infringing the TRIPs Agreement: The Problem and the Solution, 2 WASH. U. J.L. \& POL'Y 371, 372-75 (2000). For a more detailed discussion of this issue, see infra Sections V.A-B (discussing proposals to amend TRIPs to permit or require disclosure of the origin genetic resources and other information in connection with applications for biodiversityrelated patents).

122. See Convention on Biological Diversity, The Convention on Biological Diversity and the Agreement on Trade-Related Intellectual Property Rights (TRIPs): Relationships and Synergies, para. 33, U.N. Doc. UNEP/CBD/COP/3/23 (Oct. 5, 1996) [hereinafter Relationships and Synergies].

123. "Prior art" has been defined as the entire body of knowledge which was available to the public before the filing or priority date for any patent, utility model, or industrial design. IGC Overview, supra note 120 , para. 78 .

124. See Carlos M. Correa, Intellectual Property Rights, the WTO and DeVeloping COUNTRIES: THE TRIPS AGREEMENT AND POLICY OPTIONS 188-89 (2000) [hereinafter CORREA, POLICY Options]; Graham Dutfield, INTEllectual Property Rights, Trade and Biodiversity 64-68 (2000); MARI, supra note 114, at 102.

125. CBD, supra note 113 , art. 1, 31 I.L.M. at 823 . The CBD gives states significant discretion over how to achieve these goals, as demonstrated in part by the repeated tempering of obligations by the phrase "as far as possible and as appropriate." Id. arts. 5-11, 14, at 825-27, 827-28. 
innovations of indigenous communities. ${ }^{126}$ The CBD achieves these objectives in part by recognizing states' sovereign right to control genetic resources within their borders and to determine conditions of access to them. Access may be granted only upon mutually agreed terms and subject to the prior informed consent of the state providing the resources. ${ }^{127}$

The CBD's sovereignty and access rules allow biodiversity-rich developing nations to act as gatekeepers, conditioning access by private parties seeking the genetic raw materials needed for future innovations upon a promise to provide compensation, technology transfers, or other benefits should those innovations prove commercially profitable. The CBD does not, however, delineate the precise conditions upon which access will be granted nor the terms under which benefit sharing will occur. These details, as well as restrictions on the use of genetic resources, are set forth in national access laws ${ }^{128}$ or in Material Transfer Agreements (MTAs), both of which have proliferated in the wake of the CBD's entry into force. ${ }^{129}$

By allowing developing states to regulate access to genetic resources and to share in the benefits arising from their use, the CBD's gatekeeping rules made such states more amenable to protecting biodiversity-related intellectual property. ${ }^{130}$ Indeed, developing countries agreed to a provision

126. Id. art. 8(j), 31 I.L.M. at 826. This article requires each contracting party, "[s]ubject to its national legislation," to "respect, preserve and maintain knowledge, innovations and practices of indigenous and local communities embodying traditional lifestyles relevant for the conservation and sustainable use of biological diversity" and also to "promote their wider application with the approval and involvement of the holders of such knowledge, innovations and practices and encourage the equitable sharing of the benefits arising from the utilization of such knowledge, innovations and practices."

127. Id. art. 3, 31 I.L.M. at 824 (recognizing states' "sovereign right to exploit their own resources pursuant to their own environmental policies"); id. art. 15(1), at 828 (recognizing that "the authority to determine access to genetic resources rests with the national governments"); id. art. 15(4), at 828 (noting that "[a]ccess . . . shall be on mutually agreed terms"); id. art. 15(5), at 828 (noting that access shall be "subject to prior informed consent" of the state providing access).

128. As of 2002, more than 30 countries-mostly developing nations-had adopted or were considering enacting laws governing third party access to biodiversity-related resources located within their borders. Michel Petit et al., Why Governments Can't Make Policy: The Case of Plant GENETIC RESOURCES IN THE INTERNATIONAL ARENA 49 \& $80 \mathrm{n} .1$ (2001) (citation omitted).

129. Material Transfer Agreements (MTAs), sometimes referred to as biodiversity prospecting contracts, are agreements between, on the one hand, national governments or indigenous peoples that own or control access to biodiversity resources and, on the other, the commercial entity that seeks access to those resources. HeLfER, IPRS IN PLANT VARIETIES, supra note 38, at 10 . They "consist of enforceable agreements between the provider and recipient of the transferred genetic materials which create specific rights and obligations for each party." Intergovernmental Committee on Intellectual Property and Genetic Resources, Traditional Knowledge and Folklore, Operational Principles for Intellectual Property Clauses of Contractual Agreements Concerning Access to Genetic Resources and Benefit-Sharing, Second Session, Geneva, Dec. 10-14, 2001, para. 4, WIPO Doc. WIPO/GRTKF/IC/2/3 (Sept. 10, 2001).

130. The CBD expressly links intellectual property rights to the issue of access and technology transfers. The drafters envisioned that technology would function as a quid pro quo for access. Nations rich in biodiversity but poor in the skills needed to exploit it agreed to facilitate access to genetic resources in exchange for a commitment by technology-rich states to "provide and/or facilitate access for and transfer to other Contracting Parties of technologies" relevant to conservation and sustainable use. CBD, supra note 113, art. 16(1), 31 I.L.M. at 829. But because the Convention does not mandate technology transfers, the drafters tried to encourage them by obligating CBD members who receive such technologies to provide "adequate and effective" protection of intellectual property rights. See also Jim Chen, Diversity and Deadlock: Transcending Conventional Wisdom on the Relationship Between 
recognizing the need for "adequate and effective protection of intellectual property rights." ${ }^{131}$ But the CBD also obligates states "to ensure that such rights are supportive of and do not run counter to" the Convention's objectives. ${ }^{132}$ Even this weak attempt to influence intellectual property rules was strongly opposed by the United States (which signed but refused to ratify the CBD) ${ }^{133}$ and the United Kingdom, France, Italy, and Switzerland (which did ratify the Convention, but subject to interpretive statements). ${ }^{134}$

\section{Intellectual Property Lawmaking by the Conference of the Parties}

Given the high level of discord over biodiversity-related intellectual property rights, the precise relationship between CBD and TRIPs-including the degree to which they conflict with or complement each other-has been a subject of intense and continuing interest by member states participating in the COP. ${ }^{135}$ Official COP statements "[s]tress[] the need to ensure consistency in implementing" the two agreements by "promoting increased mutual supportiveness and integration of biological diversity concerns and the protection of intellectual property rights." ${ }^{136}$ COP member states have worked toward this goal using the tools of soft lawmaking: gathering information, commissioning case studies, holding workshops, and drafting guidelines and recommendations. This generative lawmaking process has also involved widespread participation by intergovernmental organizations, NGOs, and private parties. This lawmaking has addressed, inter alia, two important

Biological Diversity and Intellectual Property, 31 ENVTL. L. REP. 10625, 10638 (2001) (stating that CBD Article 16 does not require states to transfer technologies).

131. CBD, supra note 113, art. 16(2), 31 I.L.M. at 829 (noting that access to and transfer of technology subject to intellectual property rights "shall be provided on terms which recognize and are consistent with the adequate and effective protection of" those rights).

132. Id. art. 16(5), 31 I.L.M. at 829 ("The Contracting Parties, recognizing that patents and other intellectual property rights may have an influence on the implementation of this Convention, shall cooperate in this regard subject to national legislation and international law in order to ensure that such rights are supportive of and do not run counter to its objectives.").

133. See Raustiala, supra note 118, at $492-94$ (analyzing the United States' response to the CBD). The United States was concerned that Article 16(5) "could arguably require a review of established intellectual property rights regimes ... [and] undermine US efforts to gain wider respect for intellectual property rights worldwide." Letter from William K. Reilly, Administrator, Environmental Protection Agency, to John D. Dingell, Chairman, Committee on Energy and Commerce, U.S. House of Representatives (Sept. 21, 1992), quoted in Karen Anne Goldman, Note, Compensation for Use of Biological Resources Under the Convention on Biological Diversity: Compatibility of Conservation Measures and Competitiveness of the Biotechnology Industry, 25 LAW \& POL'Y INT'L Bus. 695, 706 n.61, 712 (1994).

134. See Goldman, supra note 133, at 697 n.8; Raustiala, supra note 118, at 494-95.

135. See Richard G. Tarasofsky, The Relationship Between the TRIPs Agreement and the Convention on Biological Diversity: Towards a Pragmatic Approach, 6 REV. EUR. COMMUNITY \& INT'L ENVTL. L. 148, 148 (1997) (noting that the relationship between biodiversity and intellectual property has been "the subject of considerable rhetoric and political controversy").

136. The Relationship of the Convention on Biological Diversity with the Commission on Sustainable Development and Biodiversity-related Conventions, Other International Agreements, Institutions and Processes of Relevence, Decision IV/15, para. 9, in Report of the Fourth Meeting of the Conference of the Parties to the Convention on Biological Diversity, U.N. Environment Programme, Conference of the Parties to the Convention on Biological Diversity, at 128, 130, U.N. Doc. UNEP/CBD/COP/4/27 (June 15, 1998), http://www.biodiv.org/doc/meetings/cop/cop-04/official/cop04-27-en.pdf. 
subject areas: protecting the knowledge and innovations of indigenous communities, and access and benefit sharing issues.

Protecting the Knowledge and Innovations of Indigenous Communities. Work on this subject began in earnest in 1997 with the hosting of a workshop attended by government officials and representatives of indigenous communities. ${ }^{137}$ The COP later established an ad hoc working group, whose mandate includes providing advice on legal protection for the knowledge and innovations of indigenous and local communities. ${ }^{138}$ Since its first meeting in March 2000, the working group has recommended a variety of strategies to protect traditional knowledge, "including the use of existing intellectual property mechanisms, sui generis measures, the use of contractual arrangements, registers of traditional knowledge, and guidelines and codes of practice." 139 CBD member states meeting for the Sixth COP in April 2002 endorsed this multifaceted approach and directed the working group to consider, in coordination with WIPO and other intergovernmental organizations, sui generis systems to protect traditional knowledge. ${ }^{140}$

Intellectual Property Rights and Access and Benefit Sharing Issues. After the entry into force of TRIPs, developing states led by China and the G77 and sympathetic NGOs such as the World Wildlife Fund began to express concern over the relationship between intellectual property rights and the CBD's access and benefit sharing rules. ${ }^{141}$ The COP convened a panel of experts and later an ad hoc working group to develop guidelines to address this relationship. In October 2001, the working group published draft guidelines (the Bonn Guidelines on Access to Genetic Resources and Fair and Equitable Sharing of the Benefits Arising Out of their Utilization, or Bonn Guidelines), which the Sixth COP adopted in April 2002. ${ }^{142}$ The Bonn Guidelines' most important recommendation "encourage[s] the disclosure of the country of origin of genetic resources [and of traditional knowledge] in applications for intellectual property rights, where the subject matter of the application concerns or makes use of genetic resources [or such knowledge] in

137. See Convention on Biological Diversity, Report of the Workshop on Traditional Knowledge and Biological Diversity, U.N. Doc. UNEP/CBD/TKBD/1/3 (Dec. 15, 1997).

138. See Executive Secretary, Ad Hoc Open-Ended Inter-Sessional Working Group on Article $8(\mathrm{j})$ and Related Provisions of the Convention on Biological Diversity, Legal and Other Appropriate Forms of Protection for the Knowledge, Innovations and Practices of Indigenous and Local Communities Embodying Traditional Lifestyles Relevant for the Conservation and Sustainable Use of Biological Diversity, U.N. Doc. UNEP/CBD/WG8J/1/2 (Jan. 10, 2000).

139. Convention on Biological Diversity, Report of the Ad Hoc Open-Ended Inter-Sessional Working Group on Article 8(j) and Related Provisions of the Convention on Biological Diversity on the Work of its Second Meeting, para. 5, U.N. Doc. UNEP/CBD/COP/6/7 (Feb. 14, 2002).

140. Article 8(j) and Related Provisions, Decision VU10, in Report of the Sixth Meeting of the Conference of the Parties to the Convention on Biological Diversity, U.N. Environment Programme, Conference of the Parties to the Convention on Biological Diversity, at 155, 161-164, U.N. Doc. UNEP/CBD/COP/6/20 (May 27, 2002), http://www.biodiv.org/doc/decisions/COP-06-dec-en.pdf.

141. See supra notes 117 and 118 (discussing proposals and statements by developing governments and NGOs).

142. Access and Benefit Sharing as Related to Genetic Resources, Decision VI/24, in Report of the Sixth Meeting of the Conference of the Parties to the Convention on Biological Diversity, supra note 140, at 262 [hereinafter Bonn Guidelines]; Convention on Biological Diversity, Report of the Ad Hoc Open-Ended Working Group on Access and Benefit-Sharing, paras. 3-5, U.N. Doc. $\mathrm{UNEP} / \mathrm{CBD} / \mathrm{COP} / 6 / 6$ (Oct. 31, 2002). 
its development."143 The Guidelines advocate the use of these disclosures to monitor whether applicants have obtained the prior informed consent of the country of origin and complied with the conditions of access that that country imposed. ${ }^{144}$ The COP also invited WIPO and other intergovernmental organizations to contribute to an ambitious series of studies, including analyses of country of origin and prior informed consent disclosures in patent applications, material transfer agreements, and the role of oral evidence of prior art in examining, granting, and maintaining intellectual property rights. $^{145}$

As these recent events demonstrate, the states participating in the CBD's $\mathrm{COP}$ are taking an increasingly assertive role in the post-TRIPs environment. As a formal matter, they have accepted intellectual property rights as one method to promote compliance with the biodiversity regime. They have, accordingly, stressed "cooperation" and the need to "design and implement mutually supportive activities" with other intergovernmental organizations, including the WTO and WIPO. ${ }^{146}$ But COP member states have pointedly refrained from ceding jurisdiction over biodiversity-related intellectual property issues to these organizations and instead are attempting to influence the terms of the debate by setting agendas, convening meetings, suggesting topics for further study, proposing a memorandum of understanding with WIPO, and directing the CBD's Executive Secretary to seek observer status with the TRIPs Council. ${ }^{147}$

\section{B. Plant Genetic Resources for Food and Agriculture}

Intellectual property rights have also increasingly shaped the evolution of the international regime governing PGRs. Developing country governments initially treated these resources as public goods and challenged proprietary rights in all PGRs-whether in their natural state (in situ), in global seed banks (ex situ), or when modified through human innovation (such as new plant varieties). In response to the expansion of intellectual property rights, however, actors in the PGR regime adopted different rules for each of these three categories. Wild PGRs were made subject to the sovereignty of the state

143. Bonn Guidelines, supra note 142 at 284.

144. The Bonn Guidelines invites states "to encourage the disclosure of the country of origin of genetic resources in applications for intellectual property rights" in those cases "where the subject matter of the application concerns or makes use of genetic resources in its development, as a possible contribution to tracking compliance with prior informed consent and the mutually agreed terms on which access to those resources was granted." Id.

145. Id. at 284-85.

146. Cooperation with Other Organizations, Initiatives and Conventions, Decision VI/20, in Report of the Sixth Meeting of the Conference of the Parties to the Convention on Biological Diversity, supra note 140, at 205, 207-208.

147. Id. at 212 (requesting that the $\mathrm{CBD}$ Executive Secretary seek a memorandum of understanding with WIPO); Bonn Guidelines, supra note 142, at 286 (requesting Executive Secretary to renew application for observer status with the TRIPs Council); Article 8(j) and Related Provisions, Decision VI/10, in Report of the Sixth Meeting of the Conference of the Parties to the Convention on Biological Diversity, supra note 140, at 155, 161-62 (proposing studies on the role of intellectual property rights and access and benefit sharing); Bonn Guidelines, supra note 142, at 284-85 (proposing studies on intellectual property rights and the protection of traditional knowledge). 
in which they were located; "worked" PGRs were eligible for intellectual property protection by private parties, while the seeds and other plant materials located in international seed banks continued to be treated as the common heritage of humanity.

The expansion of intellectual property protection standards also engendered disputes over these ownership rules. ${ }^{148}$ One set of contestations concerned whether intellectual property owners should be required to compensate developing states and private parties (principally farmers) who controlled or preserved the wild PGRs that served as the raw material for later proprietary innovations in the field of plant breeding and agriculture. A second set of disputes arose over the boundary between biological materials in the public domain and those that could be privatized. Here too claims of intellectual property protection (in the form of patent claims in isolated and purified plant genes) fomented regime change, leading to the negotiation of a new treaty designed to clarify that boundary and to adopt mandatory rules for access and benefit sharing.

\section{From the Common Heritage Principle to Divided Ownership Rules}

International negotiations on PGRs take place primarily in the Commission on Genetic Resources for Food and Agriculture (CGRFA, or the Commission), ${ }^{149}$ whose secretariat is provided by the United Nations Food and Agriculture Organization (FAO). ${ }^{150}$ In the early 1980s, developing nations-led by Mexico and NGOs such as Rural Advancement Foundation International (RAFI) and Genetic Resources Action International (GRAIN)lobbied for and then worked within the CGRFA to staunch the free flow of PGRs from centers of biodiversity to plant breeding industries located in industrialized nations. ${ }^{151}$ They argued that commercial breeders were using

148. The expansion of these standards is manifested not only in the TRIPs Agreement, but also in the International Union for the Protection of New Varieties of Plants (UPOV) - a treaty system that grants sui generis intellectual property rights to commercial plant breeders, see infra note 155 -and in TRIPs-plus bilateral treaties that require developing countries to join the UPOV, incorporate UPOV rules, or extend patent protection to plants and plant varieties. See GRAIN, TRIPs-plus, supra note 10, at 2-3; Drahos, supra note 10, at 796-97, 800.

149. Commission on Genetic Resources for Food and Agriculture, Welcome to the Commission on Genetic Resources for Food and Agriculture, at http://www.fao.org/ag/cgrfa/default.htm (last visited Nov. 23, 2003). CGRFA is an intergovernmental forum created in 1983 to facilitate policy dialogue and technical discussions on genetic resource issues relating to food and agriculture. The cornerstone of CGRFA's work is the Global System on Plant Genetic Resources for Food and Agriculture, which seeks to conserve biological diversity, ensure the sustainable use of PGRs, and promote fair and equitable sharing of benefits arising from the use of those resources. Commission on Genetic Resources for Food and Agriculture, Global System on Plant Genetic Resources, at http://www.fao.org/ag/cgrfa/PGR.htm diagram (last visited Nov. 23, 2003) (describing history of global system). As of February 2003, 165 states and the European Union were members of the CGRFA. See Commission on Genetic Resources for Food and Agriculture, Members of the FAO Commission on Genetic Resources for Food and Agriculture, at http://www.fao.org/ag/cgrfa/memC.htm (Feb. 2003).

150. Commission on Genetic Resources for Food and Agriculture, Welcome to the Commission on Genetic Resources for Food and Agriculture, supra note 149. The FAO membership includes 188 states and the European Union. See Food and Agriculture Organization of the United Nations, FAO Membership (188) as at 29 November 2003, at http://www.fao.org/Legal/member-e.htm (last visited Dec. 14, 2003).

151. See BRAITHWAITE \& DRAhOS, supra note 54, at 405; PETIT ET AL., supra note 128, at 7. 
raw PGRs to develop new proprietary plant varieties without compensating the countries that had provided the raw materials for their innovations. ${ }^{152}$ To address these concerns, the CGRFA member states adopted a non-binding declaration known as the International Undertaking on Plant Genetic Resources (the Undertaking). The Undertaking stated that all PGRsnaturally occurring plants, plant materials held in genetic storage banks, and cultivated plant varieties-were part of the "heritage of mankind and consequently should be available without restriction" for scientific research, plant breeding, and conservation. ${ }^{153}$

As applied to raw PGRs located in the wild or in seed banks, the Undertaking was consistent with intellectual property rules barring protection of naturally occurring matter. ${ }^{154}$ But its applicability to cultivated plant varieties conflicted with the International Union for the Protection of New Varieties of Plants (UPOV), a multilateral agreement that industrialized states had created to protect plant breeders' rights. ${ }^{155}$ Arguing that proprietary rights in new plant varieties encourage plant breeding innovations and enhance genetic diversity, ${ }^{156}$ these states successfully lobbied for a revision of the Undertaking which stated that plant breeders' rights as protected by the UPOV were "not incompatible" with the common heritage principle. ${ }^{157}$ Yet this reconciliation also created an imbalance in the regime, permitting unrestricted access only to unimproved PGRs without requiring compensation to the states, communities, or institutions that maintained those resources. To redress this imbalance, developing states incorporated three additional rules

152. See Neil D. Hamilton, Who Owns Dinner: Evolving Legal Mechanisms for Ownership of Plant Genetic Resources, 28 TULSA L.J. 587, 600-01 (1993). Such uncompensated uses are sometimes referred to as "biopiracy," a term that has been loosely used to refer to any act by which a commercial entity seeks to obtain intellectual property rights over biological resources that are seen as "belonging" to developing states or indigenous communities. CEAS CONSULTANTS, supra note 7 , at 78.

153. International Undertaking on Plant Genetic Resources, Report of the Conference of FAO, FAO Conference, 22d Sess., art. 1, U.N. Doc. C/83/REP (1983). See also id. art. 5 (stating that governments and institutions adhering to the Undertaking will make samples of PGRs available "free of charge, on the basis of mutual exchange or on mutually agreed terms').

154. Dan Leskien \& Michael Flitner, Intellectual Property Rughts and Plant Genetic Resources: OptIONS for a SUI GENERIS SYSTEM 8 (Issues in Plant Genetic Res., No. 6, 1997) (discussing exclusion of naturally occurring substances from national patent laws); Murphy, supra note 111 , at 64 (noting that "there appears to be a consensus that intellectual property protection cannot be extended to genetic resources merely found in nature, but rather only to natural products to which there has been some intervention of human ingenuity").

155. The UPOV was adopted by several European states in 1961 to recognize and protect sui generis intellectual property rights for commercial plant breeders. The acronym UPOV comes from the French, Union Internationale pour la Protection des Obtentions Végétales. The UPOV, which has been expanded through the adoption of new Acts in 1972, 1978, and 1991, requires states to grant breeders certain exclusive rights to exploit the new plant varieties they create. For an overview of the UPOV's provisions, see Barty Greengrass, The 1991 Act of the UPOV Convention, 13 EUR. INTELL. Prop. Rev. 466 (1991); HelFER, IPRS IN PLANT VARIETIES, supra note 38, at 12-18. The text of all UPOV Acts can be found at http://www.upov.org (last visited Dec. 14, 2003).

156. The assertion that plant breeders' rights enhance genetic diversity is controversial. See LESKIEN \& FLITNER, supra note 154, at 53-54 (discussing effects on genetic diversity of different rules for protecting new plant varieties). For a discussion of policy rationales favoring breeders' rights, see Helfer, IPRs IN Plant VAReties, supra note 38, at 2; W. Lesser, THe Role of INTEllectual PROPERTY RIGHTS IN BIOTECHNOLOGY TRANSFER UNDER THE CONVENTION ON BIOLOGICAL DiVERSITY 6-8 (ISAAA Briefs, No. 3, 1997), http://www.isaaa.org/Publications/Downloads/Briefs\%203.pdf.

157. Agreed Interpretation of the International Undertaking, Res. 4/89, FAO Conference, 25th Sess., para. 1 (1989) [hereinafter Agreed Interpretation]. 
into the PGR regime: (1) farmers' rights; (2) national sovereignty; and (3) a ban on intellectual property claims over the genetic materials held in international seed banks.

Farmers' rights. Farmers' rights is a loosely defined concept that seeks to acknowledge the contributions that traditional farmers have made to the preservation and improvement of PGRs. ${ }^{158}$ Unlike other natural resources such as coal and oil, PGRs are maintained and managed by humans, who cultivate the wild plant varieties that serve as raw materials for future innovations by plant breeders. But whereas breeders obtain proprietary rights in new varieties to compensate them for the time and expense of innovation, no system of remuneration rewards farmers. Farmers' rights thus act as a counterweight to plant breeders' rights, compensating the upstream input providers who make downstream innovations possible. ${ }^{\text {. }}$

Because farmers' conservation efforts and informal cultivation techniques were collective acts that occurred incrementally over many years, they did not meet the subject matter requirements for intellectual property protection. ${ }^{160}$ Developing states did not, however, seek to create a new class of legal entitlements for individual farmers. ${ }^{161}$ Instead, the revised Undertaking vested what were nominally referred to as farmers' rights in "the International Community, as trustees for present and future generations of farmers." 162 Central to this trusteeship concept was the creation of an international fund to support conservation and use of PGRs by farmers. Although lack of contributions from FAO members caused the fund to languish during the 1980 s and 1990s, developing countries have continued to seek ways to protect farmers' rights. ${ }^{163}$

National sovereignty. The second rule that developing nations, particularly those in the Latin American and Caribbean Group (GRULAC), advocated in response to the expanding intellectual property regime was sovereignty over the food and agriculture-related genetic resources located

158. Farmers' Rights, Res. 5/89, FAO Conference, 25th Sess. (1989) [hereinafter Farmers' Rights] (defining farmers' rights as "rights arising from the past, present and future contributions of farmers in conserving, improving and making available plant genetic resources particularly those in the centres of origin/diversity"); see also CARLOS M. CORREA, OPTIONS FOR IMPLEMENTATION OF FARMERS' RightS at THE National Level (South Centre, Working Paper No. 8, 2000) (on file with The Yale Journal of International Law) (discussing the evolution of the concept of farmers' rights and methods for their future recognition).

159. See Helfer, IPRS IN PLANT VARIETIES, supra note 38, at 9 (discussing the evolution of the concept of "farmers' rights").

160. Michael Blakeney, Protection of Plant Varieties and Farmers' Rights, 24 EUR. INTELL. PROP. REV. 9, 9-11 (2002); DUTFIELD, supra note 124, at 50.

161. The label "farmers' rights" has also been applied to specific farming practices (such as saving, replanting, and exchanging seeds from proprietary plant varieties) recognized in some intellectual property systems as exceptions to the exclusive rights of plant breeders, and to proposals to modify intellectual property laws to allow farmers to claim exclusive rights in the plant varieties they cultivate informally. For discussions of these two conceptions of farmers' rights, see LESKIEN \& FLITNER, supra note 154, at 44-45.

162. Farmers' Rights, supra note 158, at 1.

163. See Agreed Interpretation, supra note 157, para. 4 (discussing the use of the International Fund for Plant Genetic Resources to promote conservation, management, and utilization programs by farmers in developing countries); DUTFIELD, supra note 124, at 103 (noting that "the Fund failed on account of the lack of contributions"); PETIT ET AL., supra note 128, at 18-19 (summarizing more than a decade of debate among governments over different mechanisms to recognize farmers' rights). 
within their borders. ${ }^{164}$ Sovereignty confirmed developing states as the putative owners of PGRs, and laid the foundation for the CBD's expansion of that rule to all genetic resources. Sovereignty also softened developing countries' opposition to intellectual property rights in worked PGRs, since those rights could now function as the engine for their future remuneration. ${ }^{165}$ In particular, these countries could now demand compensation or technology transfers as a quid pro quo for access to the genetic resources subject to their sovereign control.

Public domain treatment of international seed banks. Although national sovereignty allowed developing states to control the PGRs located within their borders, a different set of policy questions arose with respect to the seeds and other plant materials stored in international gene banks. In the early 1970s, an informal association of public and private donors created an international network of agricultural research centers known as the Consultative Group on International Agricultural Research (CGIAR). The gene banks within CGIAR store and conserve seeds and other propagating materials outside of their natural habitat. They also provide samples of genetic material for agriculture, research, and plant breeding purposes, principally in developing countries. ${ }^{166}$

Agreements between individual members of CGIAR and FAO designate most genetic materials in the CGIAR network as held "in trust for the benefit of the international community."167 These agreements preclude research centers from claiming intellectual property rights over trust materials and related information, and direct them to impose the same ban in agreements with third parties seeking access to seed banks. ${ }^{168}$ As a result, CGIAR research centers have treated the seeds and plant materials under their control as part of

164. See Earth Negotiations Bulletin, The Draft Global Plan of Action on PGR, at http://www.iisd.ca/linkages/vol09/0940006e.html (statement by Colombia noting regional meeting of GRULAC and support for, inter alia, sovereignty of states over genetic resources and harmonization of legal instruments, including those concerning intellectual property rights). The national sovereignty principle was adopted in a 1991 Annex to the Undertaking, effectively subordinating the common heritage principle. Res. 3/91, FAO Conference, 26th Sess., at 1 (1991) (recognizing that "the concept of mankind's heritage, as applied in [the Undertaking], is subject to the sovereignty of the states over their plant genetic resources").

165. This softened stance was reflected in the 1991 Annex to the Undertaking, which adopted a more intellectual property-friendly amendment stating that "breeders' lines and farmers' breeding material should only be available at the discretion of their developers during the period of development." Res. 3/91, supra note 164 , at 2.

166. "The CGIAR network holds the world's largest ex situ collections of plant genetic resources, with 600,000 accessions of improved [plant] varieties and wild species." DUTFIELD, supra note 124 , at 105 .

167. Agreement Between [name of Centre] and the Food and Agriculture Organization of the United Nations (FAO) Placing Collections of Plant Germplasm Under the Auspices of FAO, art. 3(a) (1994), reprinted in BOOKLET OF CGIAR CENTRE POLICY INSTRUMENTS, GUIDELINES AND STATEMENTS ON GENETIC RESOURCES, Biotechnology and InTEllectual Property Rights 2, 3 (Version 2, July 2003) (setting forth common texts of agreements between individual CGIAR members and FAO).

168. Id. art. 3(b), at 3 (stating that a research center "shall not claim legal ownership over the designated germplasm, nor shall it seek any intellectual property rights over that germplasm or related information"); id. art. 10, at 5 (requiring centers to impose the same restrictions in Material Transfer Agreements (MTAs) with third parties). For an analysis of MTAs, see Operational Principles for Intellectual Property Clauses of Contractual Agreements Concerning Access to Genetic Resources and Benefit-Sharing, Intergovernmental Committee on Intellectual Property and Genetic Resources, Traditional Knowledge and Folklore-Second Session, Geneva, Dec. 10-14, 2001, WIPO Doc. WIPO/GRTKF/IC/2/3 (Sept. 10, 2001). 
the public domain. ${ }^{169}$ But in several widely publicized cases in the 1990 s, plant breeders and other entities received intellectual property rights in plant varieties based on materials transferred from the CGIAR collections. At issue in these cases was whether the claimants had sought rights over the raw plant materials received from CGIAR, or whether they had sufficiently modified the materials to justify their privatization. ${ }^{170}$ This tension reflected a broader debate between industrialized and developing states over whether national laws should grant intellectual property rights in plant genetic materials that are merely isolated and purified from their natural state. ${ }^{171}$

\section{The International Treaty on Plant Genetic Resources for Food and Agriculture}

By the early 1990s, developing country governments had successfully incorporated each of the three rules identified above - farmers' rights, national sovereignty, and public domain treatment of CGIAR seed holdings-into the PGR regime, in part as a counterweight to biotechnology patents and plant breeders' rights. But those rules were reflected only in soft law declarations that were normatively underdeveloped or contested by many industrialized states. For this reason, these governments sought to create legally binding rules to address these issues more conclusively. In the case of genetic resources generally, states negotiated the CBD, discussed in detail above. But the Convention did not address PGRs for food and agriculture, including farmers' rights and access to the collections of international seed banks. Those issues were left to the CGRFA, which in 1994 became the forum for revising the Undertaking into a binding international agreement. ${ }^{172}$ Seven years of contentious negotiations-begun just after the conclusion of the TRIPs Agreement in 1994 ended in November 2001 with the adoption of a new International Treaty on Plant Genetic Resources for Food and Agriculture (ITPGR). ${ }^{173}$

169. PETIT ET AL., supra note 128 , at 11 .

170. See Rural Advancement Foundation International, An Inquiry into the Potential of Plant Piracy Through International Intellectual Property Conventions, Plant Breeders Wrongs, HSCA/RAFI (Version 3, 1999) (on file with The Yale Joumal of International Law); see also DUTFIELD, supra note 124 , at 50 (noting disputes over intellectual property rights granted in plant varieties acquired from the CGIAR that are alleged to "have been subjected to little, if any, additional breeding").

171. Compare Council Directive 98/44/EC, art. 3.2, 1998 O.J. (L 213) 13, 18 (stating that "biological material which is isolated from its natural environment or produced by means of a technical process" may be patentable), and LESKIEN \& FLITNER, supra note 154, at 8 (discussing patenting of isolated and purified natural substances in the United States and European Union), with CORREA, POLICY OPTIONS, supra note 124, at 186 (discussing contrary policy adopted by many developing countries), and Jayashree Watal, INTEllectual Property Rights IN THE WTO aNd DeVEloping Countries 155-56 (2000) (same).

172. Nairobi Final Act of the Conference for the Adoption of the Agreed Text of the Convention on Biological Diversity, Resolution 3: The Interrelationship Between the Convention on Biological Diversity and the Promotion of Sustainable Agriculture (May 22, 1992), reprinted in SECRETARIAT OF the Convention on Biological Diversity, HandBook of the Convention on Biological DIVERSITY 287 (2d ed. 2003), http://www.biodiv.org/doc/handbook/cbd-hb-09-en.pdf (recognizing need for future negotiations within the FAO on access to ex situ collections and farmers' rights).

173. International Treaty on Plant Genetic Resources for Food and Agriculture, Nov. 3, 2001, http://www.fao.org/ag/cgrfa/IU.htm [hereinafter ITPGR]. See MOHAMED Ali MEKOUAR, A GLOBAL INSTRUMENT ON AGROBIODIVERSITY: THE INTERNATIONAL TREATY ON PLANT GENETIC RESOURCES FOR 
In addition to recognizing farmers' rights, ${ }^{174}$ the ITPGR's principal aim is to facilitate the exchange of seeds and other plant materials for research, breeding, and crop development purposes. The treaty promotes this exchange by establishing a new "multilateral system" to which member states and their nationals will be granted "facilitated access." 175 In essence, the multilateral system is a communal seed treasury composed of thirty-five food and twentynine feed crops held both by states and CGIAR gene banks. In exchange for access to this common seed pool, private parties that create commercial products which incorporate PGRs received from the multilateral system must pay a percentage of their profits into a fund to be administered by the treaty's Governing Body. The fund will be used to promote conservation and sustainable use of PGRs, particularly by farmers in developing countries, whose conservation efforts the treaty expressly recognizes. ${ }^{176}$

With respect to intellectual property rights, the fulcrum of the debate focused on whether the ITPGR would bar the patenting of isolated and purified genes extracted from a seed placed in the common seed pool. Such a ban would not conflict with TRIPs, which permits WTO members to exclude plants and plant varieties from patentability. ${ }^{177}$ It would, however, conflict with "TRIPs-plus" bilateral treaties that require developing governments to recognize such inventions and with national patent laws in industrialized countries that treat isolated and purified genes as patentable inventions. ${ }^{178}$ After lengthy negotiations, government delegates adopted a compromise stating that facilitated access to the multilateral system will only be provided on condition that " $[r]$ ecipients shall not claim any intellectual property or other rights that limit the facilitated access to the plant genetic resources for food and agriculture, or their genetic parts or components, in the form received from the Multilateral System."179 To avoid the possibility that this

FOOD AND AGRiculture 3 (FAO Legal Papers Online, No. 24, 2002), at http://www.fao.org/Legal/prsol/po24.pdf (stating that ITPGR was "the result of a laborious and lengthy, hard-fought seven-year negotiating process").

174. ITPGR, supra note 173, art. 9.2 ("In accordance with their needs and priorities, each Contracting Party should, as appropriate, and subject to its national legislation, take measures to protect and promote Farmers' Rights, including (a) protection of traditional knowledge relevant to [PGRFA]; (b) the right to equitably participate in sharing benefits arising from the utilization of [PGRFA]; and (c) the right to participate in making decisions, at the national level, on matters related to the conservation and sustainable use of [PGRFA]").

175. Id. art. 11 (describing the article that defines coverage of the multilateral system); $i d$. art. 12 (describing the article that defines mechanisms of facilitated access to PGRs within the multilateral system).

176. For useful discussions of the ITPGR's functions, see MEKOUAR, supra note 173, at 5-10; The Law of the Seed!, ETC TRANSLATOR (ETC Group, Winnipeg, Can.), Dec. 2001, http://www.etcgroup.org/documents/trans_treaty_dec2001.pdf.

177. See HELFER, IPRS IN PLANT VARIETIES, supra note 38, at 25-26, 52.

178. See GRAIN, TRIPs-plus, supra note 10, at 2-3 (identifying patent protection for plants as a "TRIPs-plus" standard and listing bilateral agreements that require developing countries to grant such protection).

179. ITPGR, supra note 173, art. 12.3(d) (emphasis added). A review of the final stages of the ITPGR's drafting history is essential to decipher Article 12.3(d)'s cryptic text. Two different phrases"or their genetic parts or components" and "in the form"-were included as separate bracketed texts going into the final round of negotiations. Developing states that opposed patent protection sought to retain the first clause and delete the second, whereas the United States wanted the first phrase deleted and the second retained. In the end, both clauses were retained after the United States lost, by a 97 to 10 margin, a vote to have Article 12.3 (d) deleted from the treaty. The entire treaty was then adopted by a 
language might be read to conflict with TRIPs or domestic patent statutes, Australia, Canada, Japan, and the United States appended interpretive statements after the final round of negotiations indicating their view that nothing in the ITPGR is inconsistent with national or international intellectual property laws. ${ }^{180}$

A second potential conflict with TRIPs concerns the ITPGR's rules on benefit sharing, which require entities that develop a commercial product from genetic resources in the multilateral system to pay into a trust account "an equitable share of the benefits arising from the commercialization of that product." $"$ Some commentators have asserted that this provision may violate TRIPs by imposing an obligation on biotechnology patent holders that is not imposed on other patent owners. ${ }^{182}$ Whether such a disparate benefit sharing rule in fact conflicts with TRIPs is uncertain, however, given a WTO panel decision rejecting the claim that a facially neutral statute which in practice applied to pharmaceuticals violated TRIPs's patent non-discrimination rule. ${ }^{183}$

These textual ambiguities in the ITPGR create opportunities for the treaty's new Governing Body to clarify the role of TRIPs and intellectual property rights generally in achieving the treaty's objectives. In anticipation of the treaty's entry into force, ${ }^{184}$ the FAO Conference has already directed the

vote of 116 in favor, zero against, and two abstentions by Japan and the United States. See EarTH Negotiations Bull. (Int'l Inst. for Sustainable Dev., Winnipeg, Can.), Nov. 5, 2001, at 5-8.

Given the ambiguities in Article 12.3(d), governments and commentators are divided over whether the act of extracting a gene from a seed is, in itself, a sufficient alteration of the seed's genetic material such that the extracted genetic product is no longer "in the form received" from the multilateral system. Compare MeKouAR, supra note 173, at 7 n.26 (noting that Australia, Canada, Japan, and the United States were concerned that Article 12.3(d) "could impinge on their IPR laws and policies" but that the European Union viewed the article as "consistent with IPRs") with The Law of the Seed!, supra note 176, at 4 (stating that Article 12.3(d) can be read to require that original plant material, including genetic components, remains within the multilateral system free for others to use and exploit).

180. See Agriculture and Agri-Food Canada, Analysis of Issues Raised by the International Treaty on Plant Genetic Resources for Food and Agriculture, http://pgrc3.agr.gc.ca/itpgrfa/iprdpr_e.html (last visited Dec. 9, 2003) (reprinting official interpretation by Canada that Article 12.3(d) "do[es] not in any way modify or limit intellectual property rights as protected by international agreements" and stating that this interpretation is shared by the United States, Japan, Australia, and the European Union); FAO Conference, 31 st Sess., 4th plen. mtg. at 12-15, 17-18, U.N. Doc. C/2001/PV/4 (2001).

181. ITPGR, supra note 173, art. 13.2(d)(ii). Payments are mandatory when the owner of the commercial product restricts its use in future research and breeding and voluntary when the product is freely available for such purposes. See id.

182. See Robert J.L. Lettington, The International Undertaking on Plant Genetic Resources in the Context of TRIPs and the CBD, BRIDGES MONTHLY REVIEW (Int'1 Ctr. for Trade and Sustainable Dev., Geneva, Switz.), July - Aug. 2001, at 11, http://www.ictsd.org/English/BRIDGES5-6.pdf (discussing potential conflicts between TRIPs and ITPGR's benefit sharing rules). See also TRIPs, supra note 1, art. 27.1, 33 I.L.M. at 93-94 (requiring WTO members to make "patents . . available and patent rights enjoyable without discrimination as to ... the field of technology").

183. See WTO Panel Report on Canada-Patent Protection of Pharmaceutical Products, para. 7.105 \& n.439, WTO Doc. WT/DS114/R (Mar. 17, 2000) (rejecting claim that Section 55.2(1) of Canada's Patent Act created de jure or de facto discrimination against pharmaceutical patents in violation of TRIPs Article 27.1 and expressly refusing to decide whether "measures that are limited to a particular area of technology . . . are necessarily 'discriminatory' by virtue of that fact alone, or whether under certain circumstances they may be justified as special measures needed to restore equality of treatment to the area of technology in question").

184. The ITPGR will enter into force three months after its ratification by forty contracting parties. ITPGR, supra note 173, art. 28. As of June 2003, the ITPGR had not received the ratifications needed to enter into force. It had, however, been signed or acceded to by eighty-seven states (including the United States, all fifteen EC members, and numerous developing countries) and ratified by nineteen 
CGRFA to cooperate with other international organizations to prepare a draft MTA for the Governing Body to consider at its first session. ${ }^{185}$ This work program suggests that the Governing Body will take an active role in intellectual property lawmaking for the foreseeable future.

\section{Public Health}

The World Health Organization (WHO), founded in 1946, is the primary intergovernmental organization responsible for promulgating principles, norms, and rules concerning public health. The WHO's lawmaking activities have addresses pharmaceuticals since the mid-1970s, when the organization first introduced the concept of "essential drugs" and urged its member states to adopt "national drug policies." ${ }^{186}$ But its concern over the intellectual property rights in those pharmaceuticals arose only after the TRIPs Agreement entered into force and expanded states' obligations to protect pharmaceutical patents. The response of the public health regime to this expansion of intellectual property rights has been both skeptical and pragmatic. Since 1996, the WHO has closely monitored the implementation of TRIPs, advising WHO member states on ways to achieve their national health goals by making use of so-called "safeguards" already in TRIPs that grant flexibility to balance intellectual property protection against public health objectives. ${ }^{187}$

Brazil, South Africa, and Zimbabwe, together with public health NGOs such as the Consumer Project on Technology (CPT), Medecins sans Frontières (MSF), Health Action International (HAI), and Oxfam, were the principal catalysts for the WHO's critical review of TRIPs. ${ }^{188}$ The review

states. See FAO, International Treaty on Plant Genetic Resources for Food and Agriculture, http://www.fao.org/Legal/TREATIES/033s-e.htm (last visited Dec. 14, 2003) (providing a list of participants).

185. Res. 3/2001, FAO Conference, 31st Sess., paras. 8(c), 12, reprinted in MEKOUAR, supra note 173, at 12-15. See also Comm'n on Genetic Resources for Food and Agriculture acting as Interim Comm. of the ITPGR, 1st mtg., Annex D, U.N. Doc. CGRFA-MIC-1/02/REP (2002) (setting forth terms of reference for expert group that will recommend terms to be included in a standard MTA).

186. See WORld Health ORganization, WHO MEdicines STRATEgy: Framework fOR ACTION IN EsSENTIAL DRUGS AND MEdICINES POLICY 2000-2003, at 7, WHO Doc. WHO/EDM/2000.1 (2000), http://www.who.int/medicines/strategy/strategy.pdf [hereinafter WHO MEDICINES STRATEGY] (defining the concept of essential drugs as "focus[ing] therapeutic decisions, professional training, public information, and financial resources on those drugs that represent the best balance of quality, safety, efficacy and cost for a given health setting"); Report of the WHO Expert Committee on National Drug Policies, at 18-20, WHO Doc. WHO/DAP/95.9 (1995) (defining components of national drug policies for WHO member governments that are intended to make essential drugs available and affordable to those who need them). The essential drug concept has led the WHO and its member governments to adopt lists of essential drugs as part of their national drug policies. Id. at 19. The WHO itself publishes a Model List of Essential Drugs and updates it every two years. See WHO MEDICINES STRATEGY, supra, at 58.

187. WHO MEDICINES STRATEGY, supra note 186 , at 36 (stating that the "WHO is ... helping countries to apply the safeguards incorporated in the TRIPS Agreement").

188. See Jose Marcos Nogueira Viana, Intellectual Property Rights, The World Trade Organization and Public Health: The Brazilian Perspective, 17 CoNN. J. INT'L L. 311, 311 (2002) (explaining efforts by Brazil to promote access to medicines in international fora including the WHO); Sell, Access to Medicines, supra note 8, at 504-07 (listing NGOs involved in the access to medicines campaign and documenting their efforts to pressure WHO to adopt positions critical of TRIPs, including a request by Zimbabwe's Minister of Health to NGOs to produce a draft resolution for a WHO Revised Drug Strategy and its presentation by top South African health official to the World Health Assembly); see also Ellen 't Hoen, TRIPs, Pharmaceutical Patents, and Access to Essential Medicines: A Long Way 
commenced in 1996 with a resolution on a Revised Drug Strategy, which requested the WHO's Director-General to "report on the impact of the work of the WTO with respect to national drug policies and essential drugs and make recommendations for collaboration between WTO and WHO, as appropriate." 189 This resolution led to the publication in 1998 of a WHOsponsored guide to the public health consequences of TRIPs. ${ }^{190}$ The guide recommended that states make use of flexibilities already contained in TRIPs-including its transition periods, parallel importation rules, and compulsory licensing provisions - to minimize the effects of pharmaceutical patents on limiting the availability of essential drugs. It also advocated that developing countries "establish a joint position vis-à-vis these hotly debated questions." 191

The WHO's entry into intellectual property issues was controversial, and became even more so as NGOs pressured the organization to adopt policy positions critical of TRIPs. According to the Coordinator of the Globalization Project for MSF, even the moderate positions espoused in the WHO's 1998 guide were viewed as a threat by the United States and European countries, which attempted unsuccessfully to suppress its publication. ${ }^{192}$ U.S. pressure did, however, result in the deletion of statements in a World Health Assembly resolution highlighting "the negative impact of new world trade agreements on ... the issue of access to and prices of pharmaceuticals in developing countries" and urging states "to ensure that public health rather than commercial interests have primacy in pharmaceutical and health policies."193 The final resolution was milder in tone, requesting that the WHO "monitor[] and analy[ze] the pharmaceutical and public health implications of relevant international agreements, including trade agreements, so that Member States . .. are able to maximize the positive and mitigate the negative impacts of those agreements." 194

Although industrialized states initially opposed granting the WHO competence to review health-related intellectual property issues, the EC later changed course in the face of a growing HIV/AIDS crisis. It "acknowledge[d] the concerns of developing countries" and dropped its objections to their use of compulsory licenses to increase access to patented pharmaceuticals. ${ }^{195} \mathrm{In}$ the wake of the EC's policy shift, the WHO adopted an approach that is

from Seattle to Doha, 3 CHI. J. INT'L L. 27, 33 (2002) ("NGOs have played a key role in drawing attention to provisions of TRIPS that can be used to increase access to medicines.").

189. Revised Drug Strategy, Res. WHA49.14, World Health Assembly, para. 2(10) (1996).

190. Germán Velásquez \& Pascale Boulet, Globalization and access to Drugs: PERSPECTIVES ON THE WTO/TRIPS AGREEMENT (rev. ed. 1999), WHO Doc. WHO/DAP/98.9, http://www.who.int/medicines/library/dap/who-dap-98-9-rev/who-dap-98-9rev.pdf.

191. Id. at 42.

192. 't Hoen, supra note 188, at 36 ("The US and a number of European countries unsuccessfully pressured the WHO in an attempt to prevent publication of the [1998] guide."). See also OXFAM, FATAL SIDE EFFECTS: MEDICINE PATENTS UNDER THE MICROSCOPE 40 (2001) (noting "dogged resistance from some industrialised countries, led by the United States" to allowing WHO to review intellectual property issues).

193. Chakravarthi Raghavan, Health: Assembly Adopts New Revised Drug Strategy, SoutHNORTH DEVELOPMENT MONITOR, May 24, 1999, http://www.twnside.org.sg/title/assembly-cn.htm (noting deletion of these statements from proposed resolutions).

194. Revised Drug Strategy, Res. WHA52.19, World Health Assembly, para. 2(7) (1999).

195. 't Hoen, supra note 188 , at 37. 
skeptical of intellectual property rights, but offers pragmatic suggestions for states to reconcile competing regime objectives. ${ }^{196}$

A March 2001 bulletin explains the essential elements of WHO policy. ${ }^{197}$ The bulletin accepts that patents create necessary incentives for the development of new drugs, but questions whether those incentives are adequate to ensure investment in medicines needed by the poor. With respect to pharmaceutical patents, the bulletin emphasizes that essential drugs are different than other commodities, and it advocates the use of "TRIPscompliant mechanisms" to lower drug prices and increase their availability. ${ }^{198}$ These mechanisms include the full spectrum of "safeguards" that TRIPs makes available, including patent eligibility standards "which reflect public health concerns," legislation authorizing "compulsory licensing [and] exceptions to exclusive rights," extension of TRIPs's transition periods, and "[p]arallel importation of a patented drug from countries where it is sold more cheaply." 199 Finally, the bulletin recommends against implementing TRIPsplus intellectual property protection standards (such as standards more stringent than those mandated by TRIPs) and urges governments to monitor the implementation of TRIPs to formulate comprehensive proposals for reviewing the treaty in the future. ${ }^{200}$

Most recently, in May 2003, WHO member states adopted a resolution establishing a new body to examine the effect of intellectual property protection on the development of new drugs. The new body will "collect data and proposals from the different actors involved and produce an analysis of intellectual property rights, innovation, and public health, including the question of appropriate funding and incentive mechanisms for the creation of new medicines and other products against diseases that disproportionately affect developing countries." 201 The resolution also urges member states "to reaffirm that public health interests are paramount in both pharmaceutical and health policies," and "to consider, whenever necessary, adapting national

196. The WHO's approach to intellectual property issues relating to public health should be contrasted with the position adopted by the U.N. human rights bodies, which have been far more critical of intellectual property protection in this area. See infra Subsection III.D.2. For discussions of other intergovernmental organizations whose work is relevant to TRIPs and access to medicines, see Frederick M. Abbott, The Doha Declaration on the TRIPS Agreement and Public Health: Lighting a Dark Corner at the WTO, 5 J. INT'L ECON. L. 469, 475-78 (2002) [hereinafter Abbott, Doha Declaration] (discussing the U.N. Development Programme, UNAIDS, the World Bank, IMF, and the European Union); 't Hoen, supra note 188 , at $36-38$ (same).

197. World Health Organization, Globalization, TRIPs and Access to Pharmaceuticals, WHO Policy Perspectives on Medicines, No. 3, WHO Doc. WHO/EDM/2001.2 (Mar. 2001) [hereinafter WHO Policy Perspectives]. A similarly balanced approach appears in two recent resolutions of the World Health Assembly. Scaling Up the Response to HIV/AIDS, Res. WHA54.10, World Health Assembly, para. 1(10) (2001) (urging members, "in order to increase access to medicines, to cooperate constructively in strengthening pharmaceutical policies and practices, including those applicable to generic drugs and intellectual property regimes, in order further to promote innovation and the development of domestic industries consistent with international law"); WHO Medicines Strategy, Res. WHA54.11, World Health Assembly, para. 1(5) (2001) (same).

198. WHO Policy Perspectives, supra note 197, at 5-6.

199. Id. at 6.

200. Id. at 6 .

201. Intellectual Property Rights, Innovation and Public Health, Res. WHA56.27, World Health Assembly, para. 2(2) (2003). 
legislation in order to use to the full the flexibilities contained in [TRIPs]."202 The final draft of the resolution represents a compromise between developing countries led by Brazil - which argued that access to new medicines "must not be impeded by patent protection"-and the United States, which advanced a competing resolution urging member states to promote innovation by encouraging respect for strong intellectual property rights. ${ }^{203}$

These events reveal that developing states and public health NGOs have used the WHO not as a forum for rolling back intellectual property protection standards, but rather as a venue for advocating the use of flexibilities already embedded within TRIPs. As I explain below, this approach to reconciling the public health and intellectual property regimes strongly influenced the negotiating strategy adopted by developing states seeking to reaffirm their right to invoke TRIPs safeguards when confronted with public health crises. The result was the Public Health Declaration adopted by WTO members as part of the launch of the Doha round of trade negotiations. The document contains precisely such a reaffirmation and acknowledges the need for incremental adjustments to TRIPs. ${ }^{204}$

\section{Human Rights}

Another international regime that has devoted increasing attention to intellectual property issues in the last decade is the United Nations human rights system. ${ }^{205}$ Intellectual property lawmaking is occurring in a variety of different U.N. fora, including the Commission on Human Rights (the Commission), its Sub-Commission on the Promotion and Protection of

202. Id. para. 1(1)-(2).

203. WHA56/NGO News Center, Intellectual Property Rights, Innovation and Public Health, Executive Summary of Main Document (May 28, 2003), http://www.wha56.org/1054122412598/view; see also Daniel Pruzin, WHO Creates Body to Study Impact of IP on Drug Development, 20 Int'I Trade Rep. (BNA), No. 23, at 957-958 (June 5, 2003).

204. Public Health Declaration, supra note 12. For detailed analyses of the Public Health Declaration supporting these assertions, see Abbott, Doha Declaration, supra note 196, at 490-504; Carlos Correa, Implications of the Doha Declaration on the TRIPs Agreement and Public HEALTH 5-43 (WHO Health, Economics, \& Drugs EDM Series, No. 12), WHO Doc. WHO/EDM/PAR/2002.3 (2002) [hereinafter CORREA, IMPLICATIONS].

205. That the U.N. human rights system should have focused its attention on intellectual property rights only in the last ten years is somewhat curious. No less than the system's foundational document-the 1948 Universal Declaration of Human Rights-recognizes an individual's right "to the protection of the moral and material interests resulting from any scientific, literary or artistic production of which he is the author" and "to share in scientific advancement and its benefits." Universal Declaration of Human Rights, G.A. Res. 217A, U.N. GAOR, 3d Sess., at 71, U.N. Doc. A/810 (1948). Government negotiators included a nearly identical provision in the International Covenant on Economic, Social and Cultural Rights. International Covenant on Economic, Social, and Cultural Rights, Dec. 16, 1966, art. 15(1)(b)-(c), S. EXEC. Doc. D, 95-2, at 13 (1997), 993 U.N.T.S. 3, 5 (entered into force Jan. 3, 1976) [hereinafter ICESCR] (recognizing an individual's right "to benefit from the protection of the moral and material interests resulting from any scientific, literary or artistic production of which he is the author" and "to enjoy the benefits of scientific progress and its applications"). Yet for nearly half a century, these provisions were largely ignored. See Audrey R. Chapman, A Human Rights Perspective on Intellectual Property, Scientific Progress, and Access to the Benefits of Science 3 (Nov. 9, 1998) (paper presented at Panel Discussion on Intellectual Property and Human Rights), at http://www.wipo.org/tk/en/activities/1998/humanrights/papers/word/chapman.doc (characterizing ICESCR Article 15 as "the most neglected set of the provisions within an international human rights instrument whose norms are not well developed"). 
Human Rights (the Sub-Commission), the U.N. High Commissioner for Human Rights (the High Commissioner), Special Rapporteurs appointed by the Commission and Sub-Commission, and the Committee on Economic, Social and Cultural Rights (the ICESCR Committee or the Committee). These bodies adopt non-binding declarations, resolutions, recommendations, and reports concerning the internationally-recognized rights of individuals and groups, including in particular those referred to in three legal instruments that together comprise the International Bill of Rights-the Universal Declaration of Human Rights (Universal Declaration), the International Covenant on Civil and Political Rights (ICCPR), and the International Covenant on Economic, Social and Cultural Rights (ICESCR). ${ }^{206}$

Recent work on intellectual property issues within the U.N. human rights system can be divided into two distinct areas-the rights of indigenous peoples and a response to the TRIPs Agreement. Lawmaking in both of these areas has been shaped by regime shifting, as developing countries and NGOs have responded to the expansion of intellectual property rights with an abundance of soft lawmaking. In the first area, actors have adopted a skeptical view of intellectual property. Declarations and guidelines recognize the need to safeguard the cultural heritage of indigenous peoples, but also view intellectual property rights as a means for third parties to misappropriate that heritage. Accordingly, these documents question whether existing intellectual property paradigms - many of which treat indigenous knowledge as in the public domain and thus freely available for exploitation ${ }^{207}$-are appropriate legal tools for protecting indigenous culture.

In the second area, intellectual property protection rules codified in the TRIPs Agreement have been framed by NGOs, independent experts, and developing states as a threat to economic, social, and cultural rights. In response, U.N. human rights bodies have developed an antagonistic approach to TRIPs. This antagonism has led to the adoption of nonbinding declarations and interpretive statements that emphasize the public's interest in access to new knowledge and innovations and assert that states must give primacy to human rights over TRIPs where the two sets of obligations conflict.

\section{Cultural Heritage and Traditional Knowledge of Indigenous Peoples}

The Sub-Commission and Commission first considered legal mechanisms to protect the intellectual property of indigenous communities in the early 1990s. Work proceeded along two parallel tracks. The SubCommission charged the Working Group on Indigenous Populations with the

206. International Covenant on Civil and Political Rights, Dec. 19, 1966, S. ExEC. Doc. E, $95-$ 2, at 23 (1997), 999 U.N.T.S. 171 (entered into force Mar. 23, 1976); ICESCR, supra note 205; Universal Declaration of Human Rights, supra note 205.

207. See Dutfield, supra note 119, at 238 ("[Traditional knowledge] is often (and conveniently) assumed to be in the public domain. This is likely to encourage the presumption that nobody is harmed and no rules are broken when research institutions and corporations use it freely."); Tarasofsky, supra note 135, at 150-51 (noting that collective ownership and long-term existence of traditional knowledge "works against" its protection as intellectual property). 
task of writing a Draft U.N. Declaration on the Rights of Indigenous Peoples (Draft Declaration). ${ }^{208}$ The Sub-Commission also appointed a Special Rapporteur to conduct a study and later to draft Principles and Guidelines for the Protection of the Heritage of Indigenous People (Principles and Guidelines). ${ }^{209}$

The Draft Declaration recognizes the right of indigenous peoples to "the full ownership, control and protection of their cultural and intellectual property,",10 and to restitution of such property "taken without their free and informed consent or in violation of their laws, traditions and customs." 211 The Draft Declaration does not specify how these rights are to be given effect, nor does it address their relationship to international intellectual property agreements. According to one commentator, however, these rights, were they to become binding, would stand in opposition to existing approaches to intellectual property protection, including those found in TRIPs. ${ }^{212}$

Unlike the Draft Declaration, the Principles and Guidelines do not mention "intellectual property" among the rights of indigenous communities requiring legal protection. ${ }^{213}$ But the subject matter of intellectual property is encompassed within the broad definition of "heritage of indigenous peoples," which includes "cultural property" and "all kinds of scientific, agricultural,

208. See Technical Review of the United Nations Draft Declaration on the Rights of Indigenous Peoples, U.N. ESCOR Comm'n on Hum. Rts., 46th Sess., Provisional Agenda Item 15, U.N. Doc. E/CN.4/Sub.2/1994/2/Add.1 (1994) [hereinafter Draft Declaration] (transcribing text of the Draft Declaration). See also Draft United Nations Declaration on the Rights of Indigenous Peoples, Res. 1993/46, Sub-Comm'n Hum. Rts., 35th mtg. (1993) (recounting history of Draft Declaration).

209. See Study on the Protection of the Cultural and Intellectual Property of Indigenous Peoples, U.N. ESCOR, 45th Sess., Provisional Agenda Item 14, U.N. Doc. E/CN.4/Sub.2/1993/28 (1993) (initial study requested by Sub-Commission); Draft Principles and Guidelines for the Protection of the Heritage of Indigenous People, Final Report of the Special Rapporteur, U.N. ESCOR Comm'n on Hum. Rts., 47th Sess., Annex, Provisional Agenda Item 15, U.N. Doc. E/CN.4/Sub.2/1995/26 (June 21, 1995) (initial text of the draft Principles and Guidelines); Report of the Seminar on the Draft Principles and Guidelines for the Protection of the Heritage of Indigenous People, U.N. ESCOR Comm'n on Hum. Rts., 52d Sess., Provisional Agenda Item 7, U.N. Doc. E/CN.4/Sub.2/2000/26 (2000) [hereinafter Revised Draft Principles and Guidelines] (revised text of the draft Principles and Guidelines). The SubCommission later adopted the Revised Draft Principles and Guidelines and transmitted them to the Commission for its approval. Decision 2000/107, Sub-Comm'n Hum. Rts., U.N. Doc. E/CN.4/Sub.2/DEC/107/2000/107 (2000).

210. Draft Declaration, supra note 208, art. 29. This right includes "special measures to control, develop and protect their sciences, technologies and cultural manifestations, including human and other genetic resources, seeds, medicines, knowledge of the properties of fauna and flora, oral traditions, literatures, designs and visual and performing arts." Id.

211. Id. art. 12. The range of subjects to which these rights attach is broader than those recognized in intellectual property systems, and includes indigenous peoples' "sciences, technologies and cultural manifestations ... human and other genetic resources, seeds, medicines, knowledge of the properties of fauna and flora, oral traditions, literatures, designs and visual and performing arts." Id. art. 29.

212. See Rosemarie J. Coombe, Intellectual Property, Human Rights \& Sovereignty: New Dilemmas in International Law Posed by the Recognition of Indigenous Knowledge and the Conversation of Biodiversity, 6 IND. J. GloBAL LeGAL STUD. 59, 71 n.50 (1998) ("To the extent that these rights [in the Draft Declaration] may become human rights obligations . . . intellectual property rights held by others in innovations that are based upon indigenous resources or knowledge may be called into question.").

213. The document refers to "intellectual property" only in relation to "intergovernmental negotiations in the field of intellectual property rights," to which "[i]ndigenous peoples and their representative organizations should enjoy direct access." Revised Draft Principles and Guidelines, supra note 209, Annex I, para. 51. 
medicinal, biodiversity-related and ecological knowledge, including innovations based upon that knowledge."214 The skeptical approach to intellectual property protection adopted by the Principles and Guidelines is evidenced in a section addressing national laws to protect indigenous peoples' heritage. On the one hand, these laws should provide the means for indigenous peoples to prevent, as well as obtain damages for, "the acquisition, documentation or use of their heritage without proper authorization of the traditional owners" 215 - a claim that fits comfortably within existing intellectual property paradigms. But in a provision that is arguably inconsistent with TRIPs, such laws should also deny third parties the ability to obtain "patent, copyright or other legal protection for any element of indigenous peoples' heritage" that does not also provide for "sharing of ownership, control, use and benefits" with "traditional owners."216

Review and revision of the Draft Declaration and Principles and Guidelines have occurred as part of the International Decade of the World's Indigenous People (1995-2004). ${ }^{217}$ One of the Decade's principal achievements was the creation in 2000 of a new Permanent Forum on Indigenous Issues. ${ }^{218}$ The Forum, which grants indigenous peoples and their representatives equal status with state representatives, acts as a clearinghouse within the United Nations for indigenous issues, including culture and human rights. ${ }^{219}$ At its first meeting in May 2002, the Forum reviewed the activities occurring within the U.N. system relating to indigenous peoples and received information from WIPO and the WTO concerning traditional knowledge. ${ }^{220}$ The receipt and review of this information indicates that the Forum will continue to devote attention to intellectual property issues as part of its broader mandate to protect the cultural rights of indigenous peoples.

214. Id., Annex I, para. 13. Unlike existing intellectual property rules, however, indigenous peoples' rights in their heritage "are not asserted or proscribed under a specific legal entity, are not limited in terms of duration, and have potentially unlimited subject matter protection." Miriam Latorre Quinn, Note, Protection for Indigenous Knowledge: An International Law Analysis, 14 ST. THOMAS L. REV. 287, 308 (2001).

215. Revised Draft Principles and Guidelines, supra note 209, Annex I, para. 23(b).

216. Revised Draft Principles and Guidelines, supra note 209, Annex I, para. 23(c); see also Pires de Carvalho, supra note 121, at 386-89 (reviewing text and negotiating history of TRIPs and concluding that the imposition of additional disclosure or benefit-sharing requirements as a condition of patent protection would be inconsistent with TRIPs). For a discussion of proposals to amend TRIPs to require benefit sharing with developing countries and indigenous peoples, see infra Section V.B.

217. Implementation of the Programme of Activities for the International Decade of the World's Indigenous People, Report of the High Commissioner for Human Rights, U.N. ESCOR Comm'n on Hum. Rts., 58th Sess., Provisional Agenda Item 15, at 1, U.N. Doc. E/CN.4/2002/96 (2002).

218. See John Carey \& Siegfried Wiessner, A New United Nations Subsidiary Organ: The Permanent Forum on Indigenous Issues, ASIL INSIGHTS, Apr. 2001, at http://www.asil.org/insights/insigh67.htm.

219. See id. (reviewing the Permanent Forum's structure, mandate, and future work program).

220. Review of Activities of the United Nations System Relating to Indigenous Peoples: An Interactive Discussion, World Intellectual Property Organization (WIPO), U.N. ESCOR Permanent Forum on Indigenous Issues, 1st Sess., Provisional Agenda Item 6, U.N. Doc. E/CN.19/2002/2/Add.1 (2002); Review of Activities of the United Nations System Relating to Indigenous Peoples: An Interactive Discussion, World Trade Organization (WTO) Activities Relating to Indigenous Peoples, U.N. ESCOR Permanent Forum on Indigenous Issues, 1st Sess., Provisional Agenda Item 6, U.N. Doc. E/CN.19/2002/2/Add.6 (2002). 


\title{
2. United Nations Human Rights Challenges to TRIPs
}

A second and more comprehensive area of intersection between human rights and intellectual property arose in reaction to the TRIPs Agreement. As explained in Subsection II.C.3, implementing TRIPs has proven to be time consuming, expensive, and controversial for many developing countries. States and NGOs have responded to these developments by sponsoring resolutions and reports critical of TRIPs within the U.N. human rights system.

The first human rights reaction to TRIPs occurred in the SubCommission. In July 2000, an NGO consortium composed of the Lutheran World Federation, Habitat International Coalition, and the International NGO Committee on Human Rights in Trade and Investment submitted a statement on "The WTO TRIPs Agreement and Human Rights" to the Chair of the SubCommission. ${ }^{221}$ The statement contained "forceful language" that directly challenged the compatibility of TRIPs with states' human rights obligations. ${ }^{222}$ In debating a subsequent resolution on TRIPs, Sub-Commission members moderated somewhat the tone of their discussions. ${ }^{223}$ But the final, unanimous resolution they adopted on "Intellectual Property Rights and Human Rights" ${ }^{224}$ reflected an antagonistic approach to TRIPs. It stated that "actual or potential conflicts exist between the implementation of the TRIPs Agreement and the realization of economic, social and cultural rights." ${ }^{, 25}$ These conflicts cut across an exceptionally wide swath of legal terrain, including many issue areas that overlap with other international regimes and are of particular concern to developing countries. The conflicts include:

\begin{abstract}
impediments to the transfer of technology to developing countries, the consequences for the enjoyment of the right to food of plant variety rights and the patenting of genetically modified organisms, "bio-piracy" and the reduction of communities' (especially indigenous communities') control over their own genetic and natural resources and cultural values, and restrictions on access to patented pharmaceuticals and the implications for the enjoyment of the right to health. ${ }^{226}$
\end{abstract}

To address these conflicts, the Sub-Commission set out an ambitious new agenda for intellectual property lawmaking within the U.N. human rights

221. The Realization of Economic, Social and Cultural Rights, U.N. ESCOR Comm'n on Hum. Rts., 52d Sess., Provisional Agenda Item 4, at 6, U.N. Doc. E/CN.4/Sub.2/2000/NGO/14 (2002) (urging the Sub-Commission to "reassert the primacy of human rights obligations over the commercial and profit-driven motives upon which agreements such as TRIPs are based").

222. David Weissbrodt \& Kell Schoff, A Human Rights Approach to Intellectual Property Protection: The Genesis and Application of Sub-Commission Resolution 2000/7, 5 MINN. INTELL. PROP. REV. 1, 26-27 (2003). For another example of an NGO position paper critiquing TRIPs from a human rights perspective, see HIV/AIDS Legal Network \& AIDS Law Project, South Africa, TRIPs and Rights: International Human Rights Law, Access to Medicines, and the Interpretation of the WTO Agreement on Trade-Related Aspects of Intellectual Property Rights, http://www.aidslaw.ca (Nov. 2001).

223. Weissbrodt \& Schoff, supra note 222 , at 18.

224. Res. 2000/7, U.N. ESCOR Comm'n on Hum. Rts., 52d Sess., Provisional Agenda Item 4, at 1, U.N. Doc. E/CN.4/Sub.2/2000/L.20 (2000).

225. Id. at 2.

226. Id. See also id. at para. 2 (identifying conflicts between TRIPs and "the right of everyone to enjoy the benefits of scientific progress and its applications, the right to health, the right to food and the right to self-determination"). 
regime. ${ }^{227}$ The principle animating this new agenda was "the primacy of human rights obligations over economic policies and agreements."228

In the three and a half years since the resolution, U.N. human rights bodies have responded to the Sub-Commission's invitation by devoting unprecedented attention to intellectual property issues. The actions taken and documents produced by these bodies-many of which contain trenchant critiques of TRIPs - include: (1) three resolutions by the Commission on "Access to Medication in the Context of Pandemics such as HIV/AIDS," initially sponsored by Brazil, which urge states to adopt a variety of measures to ensure such access; ${ }^{229}$ (2) an analysis of TRIPs by the High Commissioner, which argues that intellectual property laws must promote the public interest in access to new knowledge and innovations, opposes the adoption of TRIPsplus standards, and emphasizes states' obligations to promote the right to health by providing access to affordable medicines to treat HIV/AIDS; ${ }^{230}$ (3) an official "statement" by the ICESCR Committee, which asserts that intellectual property rights "must be balanced with the right to take part in cultural life and to enjoy the benefits of scientific progress and its applications," and states that both "national and international intellectual property regimes must be consistent with" the obligation of states parties under the ICESCR; ${ }^{231}(4)$ a progress report by the Special Rapporteurs on

227. The Sub-Commission requested four different sets of actors - national governments, intergovernmental organizations, U.N. human rights bodies, and NGOs-to address the intersection of human rights and intellectual property. It asked national lawmakers to integrate "human rights obligations and principles" into their activities, with a particular focus on the social function of intellectual property. Id. para. 5. Similar exhortations were directed to intergovemmental organizations, which the Sub-Commission in effect urged to act as watch dogs of TRIPs by "deepen[ing] their analysis of the impacts" of the treaty and its human rights implications. Id. paras. 6, 12. The Sub-Commission's most detailed requests were aimed at other U.N. human rights bodies, whom it asked to clarify the relationship between intellectual property and human rights. Id. paras. 9-11 (requesting action by the High Commissioner, the ICESCR, and the Special Rapporteurs on Globalization). Finally, to ensure visibility for its new agenda, the Sub-Commission encouraged civil society groups to lobby governments for economic policies that fully integrated human rights obligations and "to monitor and publicize the effects of economic policies that fail to take such obligations into account." Id. para. 14.

228. Id. para. 3.

229. Res. 2001/33, U.N. ESCOR Comm'n on Hum. Rts. (2001); Res. 2002/32, U.N. ESCOR Comm'n on Hum. Rts. (2002); see also Access to Medication in the Context of Pandemics such as HIV/AIDS, Tuberculosis and Malaria, Res. 2003/29, U.N. ESCOR Comm'n on Hum. Rts. (2003). The first resolution, sponsored by Brazil in 2001, mandates that states, in implementing the right to the highest attainable standard of health, "adopt legislation or other measures, in accordance with applicable international law" to "safeguard access" to such medications "from any limitations by third parties." Res. 2001/33, supra, para. 3(b). This provision "sparked substantial controversy among Commission members . . . because it called into question the impact of" TRIPs. Michael J. Dennis, Current Development, The Fifty-Seventh Session of the UN Commission on Human Rights, 96 AM. J. INT'L L. 181,191 (2002). The United States, which abstained in the otherwise unanimous vote in favor of the resolution, "maintained that by questioning 'the validity of intemationally agreed protections of intellectual property rights,' the text was 'simply put, bad public health policy ... ." Id. at $191 \&$ n.65. The European Union voted in favor of the text but "expressed its understanding that 'no provisions in this resolution can be interpreted as undermining or limiting existing international agreements, including in the field of intellectual property." Id. at 191 \& n.66.

230. Report of the High Commissioner-The Impact of the Agreement on Trade-Related Aspects of Intellectual Property Rights on Human Rights, U.N. ESCOR Comm'n on Hum. Rts., 52d Sess., Provisional Agenda Item 4, paras. 10-15, 27-58, U.N. Doc. E/CN.4/Sub.2/2001/13 (2001) [hereinafter High Commissioner Report].

231. Substantive Issues Arising in the Implementation of the International Covenant on Economic, Social and Cultural Rights-Follow-Up to the Day of General Discussion on Article 15.1(c), 
Globalization, which asserts that intellectual property protection has undermined human rights objectives; ${ }^{232}$ (5) a second resolution by the SubCommission that identifies a widening set of conflicts between TRIPs and human rights, including "the rights to self-determination, food, housing, work, health and education, and ... . transfers of technology to developing countries"; ${ }^{233}(6)$ an effort to increase human rights visibility within the trade regime by having the High Commissioner seek observer status with the WTO and participate in reviews of TRIPs; ${ }^{234}$ and (7) a report by the U.N. Secretary General on intellectual property and human rights based on information submitted by states, intergovernmental organizations, and NGOs. ${ }^{235}$

\section{E. Overview of Intellectual Property Lawmaking in the Four Regimes}

As the foregoing discussion illustrates, the expansion of intellectual property protection standards and enforcement mechanisms in TRIPs and in other international agreements has led developing countries and NGOs to engage in regime shifting. Such shifts have been manifested by the introduction of new hard and soft lawmaking initiatives in regimes that had previously devoted no attention to intellectual property matters, and by an increased attention devoted to intellectual property issues in other regimes. Table 1 summarizes the results of these regime shifts, arranging the biodiversity, PGR, public health, and human rights regimes so that the level of contestation over intellectual property issues generally increases as one moves from the biodiversity regime on the left to the human rights regime on the right. The table notes the organizations and actors active in each regime and the regime principles that had been adopted prior to each shift. It then reviews the responses in the four regimes to the expansion of intellectual property rights and identifies the specific principles, norms, and rules that were developed in reaction to that expansion.

Statement on Human Rights and Intellectual Property, U.N. ESCOR Comm. on Econ., Soc., \& Cultural Rts., 27th Sess., Agenda Item 4, paras. 4, 11, U.N. Doc. E/C.12/2001/15 (2001) [hereinafter ICESCR Statement on Human Rights and Intellectual Property]. The speed with which the ICESCR Committee adopted this interpretive statement is noteworthy. The Committee traditionally addresses human rights topics by drafting "general comments," an often slow and deliberative process. But in this instance, it published a statement prior to a more comprehensive review of the issues, out of a desire to make a "preliminary contribution to the rapidly evolving debate on intellectual property, which remains high on the international agenda." Id. para. 2. As of December 2003, the Committee was still drafting its general comment on human rights and intellectual property.

232. J. Oloka-Onyango \& Deepika Udagama, Globalization and Its Impact on the Full Enjoyment of Human Rights, U.N. ESCOR Comm'n on Hum. Rts., 53d Sess., Provisional Agenda Item 4, paras. 19-34, U.N. Doc. E/CN.4/Sub.2/2001/10 (2001).

233. Intellectual Property and Human Rights, Res. 2001/21, U.N. ESCOR Sub-Comm'n on the Promotion and Protection of Hum. Rts., 26th mtg. (2001) (identifying "actual or potential conflicts" between human rights obligations and TRIPs, and asserting the "need to clarify the scope and meaning of several provisions of the TRIPS Agreement").

234. See High Commissioner Report, supra note 230, para. 68.

235. Report of the Secretary-General-Economic, Social and Cultural Rights, Intellectual Property Rights and Human Rights, U.N. ESCOR Comm'n on Hum. Rts., 52d Sess., Provisional Agenda Item 4, U.N. Doc. E/CN.4/Sub.2/2001/12 (2001). 


\section{TABLE 1. INTELLECTUAL PROPERTY LAWMAKING IN FOUR INTERNATIONAL REGIMES}

$\rightarrow \rightarrow \rightarrow$ Generally Increasing Contestations over Intellectual Property (IP) $\rightarrow \rightarrow \rightarrow$

\begin{tabular}{|c|c|c|c|c|}
\hline & Biodiversity & PGRs & Public Health & Human Rights \\
\hline $\begin{array}{l}\text { Intergovernmental } \\
\text { Organizations and } \\
\text { Int'l Institutions } \\
\text { Involved in } \\
\text { Regime Change }\end{array}$ & CBD's COP & CGRFA and FAO & $\begin{array}{l}\text { WHO, U.N. } \\
\text { human rights } \\
\text { bodies }\end{array}$ & $\begin{array}{l}\text { U.N. human rights } \\
\text { bodies }\end{array}$ \\
\hline $\begin{array}{l}\text { Principal Actors } \\
\text { Seeking Change in } \\
\text { Response to } \\
\text { Expansion of IP } \\
\text { Protection } \\
\text { Standards }\end{array}$ & $\begin{array}{l}\text { Developing states } \\
\text { (incl. China, G77, } \\
\text { India, and selected } \\
\text { African } \\
\text { countries), and } \\
\text { NGOs (incl. } \\
\text { Greenpeace, } \\
\text { World Wildlife } \\
\text { Fund) }\end{array}$ & $\begin{array}{l}\text { Developing states } \\
\text { (incl. Mexico and } \\
\text { other Latin } \\
\text { American \& } \\
\text { Caribbean Group), } \\
\text { and NGOs (incl. } \\
\text { RAFI \& GRAIN) }\end{array}$ & $\begin{array}{l}\text { Developing states } \\
\text { (incl. Brazil, } \\
\text { South Africa \& } \\
\text { Zimbabwe), and } \\
\text { NGOs (incl. CPT, } \\
\text { MSF, HAI \& } \\
\text { Oxfam) }\end{array}$ & $\begin{array}{l}\text { Developing states } \\
\text { (incl. Brazil), } \\
\text { NGOs (Lutheran } \\
\text { World Federation, } \\
\text { Habitat Int'1 } \\
\text { Coalition), and } \\
\text { independent } \\
\text { human rights } \\
\text { experts }\end{array}$ \\
\hline Regime Principles & $\begin{array}{l}\text { Conservation \& } \\
\text { sustainable use of } \\
\text { biodiversity; } \\
\text { controlling access } \\
\text { to biodiversity } \\
\text { through } \\
\text { sovereignty over } \\
\text { genetic resources; } \\
\text { benefit-sharing }\end{array}$ & $\begin{array}{l}\text { PGRs for food } \\
\text { and agriculture } \\
\text { treated as public } \\
\text { goods (common } \\
\text { heritage of } \\
\text { humanity) }\end{array}$ & $\begin{array}{l}\text { Promotion of } \\
\text { national public } \\
\text { health policies, } \\
\text { including national } \\
\text { drug policies and } \\
\text { lists of essential } \\
\text { drugs }\end{array}$ & $\begin{array}{l}\text { Protection of civil, } \\
\text { political, } \\
\text { economic, social, } \\
\text { and cultural rights } \\
\text { of individuals and } \\
\text { groups }\end{array}$ \\
\hline $\begin{array}{l}\text { Attitude Within } \\
\text { Each Regime to } \\
\text { TRIPs and to } \\
\text { Expansion of IP } \\
\text { Protection } \\
\text { Standards }\end{array}$ & $\begin{array}{l}\text { Accepted for } \\
\text { instrumental } \\
\text { reasons to achieve } \\
\text { regime principles } \\
\text { identified above }\end{array}$ & $\begin{array}{l}\text { Proprietary } \\
\text { approach to PGRs } \\
\text { initially contested; } \\
\text { subsequent } \\
\text { tolerance linked to } \\
\text { development of } \\
\text { new principles, } \\
\text { norms, and rules } \\
\text { identified below }\end{array}$ & $\begin{array}{l}\text { Skeptical, but } \\
\text { offering pragmatic } \\
\text { approaches for } \\
\text { reconciling } \\
\text { competing regime } \\
\text { objectives }\end{array}$ & $\begin{array}{l}\text { Antagonistic } \\
\text { (although skeptical } \\
\text { regarding the } \\
\text { cultural heritage of } \\
\text { indigenous } \\
\text { peoples) }\end{array}$ \\
\hline $\begin{array}{l}\text { Principles, Norms, } \\
\text { or Rules } \\
\text { Developed or } \\
\text { Strengthened in } \\
\text { Response to } \\
\text { TRIPs Agreement } \\
\text { and Expansion of } \\
\text { IP Protection } \\
\text { Standards }\end{array}$ & $\begin{array}{l}\text { - Sui generis IP } \\
\text { protection for } \\
\text { biodiversity- } \\
\text { related } \\
\text { traditional } \\
\text { knowledge } \\
\text { - Revising IP } \\
\text { application rules } \\
\text { (e.g., for } \\
\text { patents) to } \\
\text { promote } \\
\text { compliance with } \\
\text { access and } \\
\text { benefit sharing } \\
\text { principles }\end{array}$ & $\begin{array}{l}\text { - Farmers' rights } \\
\text { - National } \\
\text { sovereignty over } \\
\text { PGRs in the wild } \\
\text { (in situ) } \\
\text { - No IP protection } \\
\text { for PGRs in } \\
\text { international } \\
\text { seed banks (ex } \\
\text { situ) } \\
\text { - New multilateral } \\
\text { system with } \\
\text { facilitated access } \\
\text { to specified food } \\
\text { and feed crops }\end{array}$ & $\begin{array}{l}\text { - Maximizing use } \\
\text { of "safeguards" } \\
\text { in TRIPs to } \\
\text { achieve regime } \\
\text { principles } \\
\text { identified above } \\
\text { (e.g., increased } \\
\text { access to } \\
\text { patented } \\
\text { medicines) } \\
\text {-Opposition to } \\
\text { "TRIPs-plus" } \\
\text { standards }\end{array}$ & $\begin{array}{l}\text { - Primacy of } \\
\text { human rights } \\
\text { over IP } \\
\text { - Enhancing } \\
\text { public access to } \\
\text { knowledge and } \\
\text { innovations } \\
\text { - Protecting } \\
\text { cultural heritage } \\
\text { of indigenous } \\
\text { peoples from } \\
\text { misappropriation } \\
\text { - Opposition to } \\
\text { "TRIPs-plus" } \\
\text { standards }\end{array}$ \\
\hline
\end{tabular}




\section{POST-TRIPS INTELlectual PROPERTy Regime SHIfTING BY DEVELOPING STATES}

The preceding Part demonstrated that developing states, aided by NGOs and officials of intergovernmental organizations, have adopted a strategy of regime shifting to expand intellectual property lawmaking from the WTO and WIPO into international regimes governing biodiversity, PGR, public health, and human rights. Like the United States and the EC before them, developing countries have used regime shifting to modify, in different ways in each regime, the principles, norms, rules, and decision-making procedures of intellectual property protection.

Questions remain, however, over precisely which actors are promoting regime shifting and the objectives they hope to achieve by engaging in such moves. This Part considers these questions. It first explores the public choice dimension of post-TRIPs regime shifting, identifying the interest groups that are encouraging developing country governments to move intellectual property lawmaking from one international forum to another. It then considers four different rationales for regime shifting-to help achieve desired policy outcomes, to relieve political pressure for lawmaking in other international venues, to generate counterregime norms, and to integrate those norms into the WTO and WIPO. In some instances, these actions challenge the intellectual property interests of industrialized states; in others, such moves serve the objectives of both North and South.

\section{A. Public Choice Revisited}

Who are the private interest groups motivating the second wave of intellectual property regime shifting that is nominally being advanced by developing states? The answer is more complex than the public choice underpinnings of the move from WIPO to GATT to TRIPs discussed above. Some developing countries (often those furthest along the path to industrialization) have active and vocal domestic constituencies who press their governments to revise certain aspects of TRIPs or to supplement it with new intellectual property protection standards. Support for farmers' rights in India, access to patented pharmaceuticals in India and Brazil (which benefits the emerging generics industries in those countries), and national control of biological resources in Africa are three prominent examples. ${ }^{236}$

236. See Drahos, Developing Countries, supra note 8 , at $778 \&$ n. 42 . See also id. at 780 (noting scientific and interest group support in Africa for "model legislation for African states which sets out regulatory principles for the ownership and use of biological resources"); Sell, Access to Medicines, supra note 8 , at 510,516 (discussing generics industry support for greater access to patented pharmaceuticals); Shaila Seshia, Plant Variety Protection and Farmers' Rights in India: Law-Making and the Cultivation of Varietal Control (2002), at http://www.gapresearch.org/governance/ EPWarticleShaila.pdf (discussing history of legislation to protect farmers' rights in India); see also Vandana Shiva \& Radha Holla-Bhar, Piracy by Patent: The Case of the Neem Tree, in THE CASE AGAinst THE Global ECONOMY AND FOR A TURN TOWARD THE LOCAL 146, 151 (Jerry Mander \& Edward Goldsmith eds., 1996) (stating that Indian scientists, farmers, and political activists feel that 
Complementing and sometimes even supplanting these domestic interest groups are a broad array of transnational advocacy networks that provide material and moral support to developing countries negotiating intellectual property issues in different fora. ${ }^{237} \mathrm{~A}$ few of these NGOs are based in the South, but many others are based in the North. These advocacy networks advance their own normative agendas, many of which are antithetical to strong intellectual property rights. ${ }^{238}$ While these agendas may accurately reflect the interests of the NGOs' members or their leaders, they may or may not be closely aligned with the interests of developing country governments or their domestic polities.

Finally, regime shifting may be advanced by government officials themselves. Expanding the number of venues where international lawmaking takes place gives officials greater "access to foreign travel, media exposure and opportunities for advancement. ${ }^{, 239}$ For developing countries, this dynamic is reinforced by intergovernmental organizations who pay or heavily subsidize officials to travel to diplomatic conferences and similar meetings, events often hosted in the world's more cosmopolitan cities. ${ }^{240}$ Regime shifting, in this cynical view, is supported by developing country officials at least in part to enhance their prestige and importance or to obtain other personal benefits.

This brief discussion of the public choice dimension of post-TRIPs regime shifting reveals that a wide variety of government and private actors are involved in expanding international intellectual property lawmaking into biodiversity, PGR, public health, and human rights venues. It does not, however, identify what these state and nonstate actors hope to achieve by adopting this strategy. The next subsections discuss four different rationales for such moves.

multinational corporations "have no right to expropriate the fruit of centuries of indigenous experimentation").

237. See, e.g., Resource Book ON TRIPS AND DEvelopment, supra note 6; Rockefeller IP Initiative, supra note 9.

238. See CEAS ConsultanTS, supra note 7 , at 41 (identifying a dozen international NGOs opposed to various aspects of TRIPs and stating that most of these "are headquartered in the North but there are a number of organisations-both those set up by indigenous peoples/local communities, and others by more urbanised groups-that are based in developing countries but are also transnational"); Sell, Access to Medicines, supra note 8 , at 481 \& n.2 (identifying NGOs that participated in the "Access to Medicines campaign" to enhance access in developing countries to patented pharmaceuticals).

239. Stephan, Accountability and International Lawmaking, supra note 74 , at 696 . See also Dunoff \& Trachtman, supra note 74, at 399 (noting that "public choice theory suggests that treaties may advance the interests of the political elites that negotiate the treaties, rather than the broader interests of the constituents they purportedly represent").

240. See ANITA Halvorssen, Equality AMONG UNEQuals IN INTERNATIONAL Environmental Law: Differential TReatment for DeVeloping Countries 149-150 (1999) (discussing funding mechanisms designed to increase participation of developing countries in international negotiations); Drahos, Developing Countries, supra note 8, at 777-78 (noting WIPO's funding of "many meetings/seminars/training courses held in Geneva" and "generous financial assistance, for representatives from [least developed countries] to attend" diplomatic conferences); Albert Mumma, The Poverty of Africa's Position at the Climate Change Convention Negotiations, 19 UCLA J. ENVTL. L. \& POL'Y 181, 202-03 (2000-2001) (stating that officials from African countries "were able to attend [the Climate Change Convention in Buenos Aires] only because they could rely on the two air tickets availed to developing country delegates by the [CBD] Secretariat"). 


\section{B. Rationales for Intellectual Property Regime Shifting by Developing States}

\section{Laboratories for Maximizing Desired Policy Outcomes}

Regime shifting allows state and nonstate actors, particularly those that have been ignored or marginalized in other international regimes, to experiment with alternative ways to achieve desired policy outcomes. ${ }^{241}$ Incorporating an issue area from one regime into another capitalizes on the advantages that the second regime offers for obtaining such outcomes-such as different institutions, different decision-making procedures, and different compositions of actors with different types of subject matter or functional expertise. ${ }^{242}$ For NGOs, particularly those shut out of a forum by state-only access rules, ${ }^{243}$ regime shifting also offers the obvious advantage of greater access to lawmaking processes. By attending meetings, submitting documents to expert and working groups, and interacting with government officials inside and outside of negotiating halls, NGOs can shape debates over principles, norms, and rules in ways that are foreclosed to them within more state-centric regimes.

The traditional knowledge of indigenous communities provides an apt example of this type of regime shifting. Because such knowledge has often been used by local communities for generations, it falls mostly outside of the incentive-based intellectual property rights that TRIPs recognizes. ${ }^{244}$ Given this disconnect with traditional intellectual property paradigms, developing countries and NGOs interested in protecting traditional knowledge from misappropriation by third parties might reasonably have concluded that the rules needed for such protection could more easily be generated within the biodiversity or human rights regimes than by seeking an amendment to TRIPs.

Consider the many advantages that these two regimes offered to governments and NGOs interested in developing new rules to protect traditional knowledge. First, both regimes had identified traditional knowledge as a topic meriting greater international scrutiny, and had taken preliminary steps to address it even prior to TRIPs's entry into force. ${ }^{245}$ Second, both regimes emphasized soft law studies, reports, and recommendations, devices that were especially useful for experimenting with

241. Such an experimental approach is not, of course, limited to shifts between two or more public international fora. Similar benefits can sometimes be obtained where states and private parties bargain around the relevant international obligations. See Reichman \& Lange, supra note 100, at 16-17.

242. This discussion builds upon the "laboratory of ideas" rationale often used to justify regulation by local rather than national authorities within a domestic federal system. See Fed. Energy Regulatory Comm'n v. Miss., 456 U.S. 742, 788 (1981) (O'Connor, J., concurring in the judgment in part and dissenting in part) ("Courts and commentators frequently have recognized that the 50 States serve as laboratories for the development of new social, economic, and political ideas.").

243. The WTO, for example, excludes participation by non-state actors. See Relationships and Synergies, supra note 122, para. 53 (noting that NGOs "may not participate as observers or in any fashion whatsoever in any proceedings of . . . any other organ of the WTO").

244. See sources cited supra note 207.

245. In the biodiversity regime, protection was found in a binding (albeit somewhat vague) article in the CBD. In the human rights regime, two different standard setting initiatives were under way, suggesting a strong commitment to the issue. 
alternative approaches to regulating issues about which even ardent proponents of greater legal protection had yet to reach consensus. Third, both regimes welcomed input from non-state actors, allowing indigenous communities and their advocates to influence the thinking of government negotiators and intergovernmental officials in ways that would have been impossible in state-to-state negotiations in the WTO. Fourth, taking up traditional knowledge as a biodiversity or human rights issue allowed states to analyze not only its intellectual property aspects, but also the many related subjects (such as conserving biodiversity or preserving indigenous cultural heritage) to which it was closely linked. Finally, developing states and NGOs had significant influence in both regimes, suggesting that they could be effective in placing traditional knowledge protection on the legislative agenda and in seeing that agenda through to fruition.

\section{Creating Safety Valves}

The foregoing explanation for regime shifting assumes that government officials seek new venues in which to develop rules to govern a particular issue area in the belief that such rules are normatively desirable. A more skeptical view of regime shifting is also plausible, however. Far from seeking to promote particular rules as desired ends, states and interest groups can use regime shifting as a safety valve, consigning an issue area to a venue where consequential outcomes and meaningful rule development are unlikely to occur.

To understand why regime shifting might function as a safety valve, recall that governments negotiating in international fora are subject to multiple competing pressures-from different domestic constituencies, from other states, and from international advocacy organizations. Government officials confronted with such competing pressures face a choice. They can attempt to reconcile these competing claims, negotiating compromises that may suboptimally serve their interests. Or they can attempt to diffuse those pressures by taking action in regimes whose institutional structures or enforcement mechanisms are weak, thereby appeasing interest groups while avoiding action in other venues where rulemaking would have more far-reaching and less desirable consequences. ${ }^{246}$

Evidence suggests that both developing and industrialized states have used intellectual property regime shifting in the post-TRIPs era to relieve domestic pressures for action in the WTO. Consider again traditional knowledge-this time from a very different perspective. Many developing country governments face demands by indigenous communities and their advocates to protect such knowledge. By raising traditional knowledge issues in the biodiversity and human rights regimes, these governments can appear to be taking a principled stand on issues of importance to these domestic and

246. Cf. Gregory C. Shaffer, The World Trade Organization Under Challenge: Democracy and the Law and Politics of the WTO's Treatment of Trade and Environment Matters, 25 HARV. ENVTL. L. REV. 1, 38 (2001) (noting statement by government officials that in the WTO, unlike other U.N. organizations, "words have consequences"). 
international interest groups. In fact, however, most developing countries "do very little about [traditional knowledge] at the national level."247 Such inactivity is easier to justify if lawmaking on traditional knowledge occurs within regimes where binding legal commitments are drafted in vague and open-ended language and where emphasis is placed on soft law activities that do not require an immediate response by states. By contrast, if traditional knowledge were incorporated into the WTO, with its precise treaty rules and strong monitoring and enforcement mechanisms, the protection of traditional knowledge in national laws would be far more difficult to avoid.

A safety valve explanation for regime shifting also explains why industrialized countries-which would be expected to oppose revision of intellectual property protection rules-might nonetheless acquiesce to efforts by developing states and NGOs to undertake such revisions in venues other than the WTO or WIPO. Governments in industrialized countries themselves often face pressures from domestic constituencies opposed to strong intellectual property rights ${ }^{248}$ - pressures that might be relieved by endorsing or at least tolerating revisionist intellectual property agendas within weaker regimes. But even in the absence of such domestic demands, officials in industrialized countries might reasonably believe that the non-binding resolutions and recommendations that these regimes generate would be of little consequence, and surely far less threatening than amendments to hard law treaty rules. ${ }^{249}$ Indeed, regime shifting might actually serve industrialized states' interests by diverting attention and resources from potentially effective treaty-making efforts in WIPO ${ }^{250}$ or the WTO while simultaneously creating the appearance of sharing developing countries' concerns over imbalanced intellectual property standards. Seen from this vantage point, developing states and NGOs may have enjoyed a comparatively freer hand to engage in intellectual property lawmaking in the biodiversity, PGR, public health, and human rights regimes precisely because such actions were not seen as a threat

247. Dutfield, supra note 119 , at 239.

248. See, e.g., Letter from Senator Tom Daschle, Senate Majority Leader, to Barbara Tobias, U.S. Department of State (Nov. 1, 2001), reprinted in The Law of the Seed!, supra note 176, at 12 (urging United States delegates to CGRFA to support the ITPGR, which includes provisions arguably inconsistent with U.S. patent standards); Sell, Access to Medicines, supra note 8, at 498-500 (discussing the "post-TRIPs opposition campaign on health care issues" conducted by NGOs in the United States).

249. See Steinberg, supra note 69, at 340 (noting argument of realist international relations scholars that powerful states agree to accept majority voting in intergovernmental organizations that produce soft law because such law "poses little risk that powerful states would be bound by legal undertakings they might disfavor"). See also Dutfield, supra note 119, at 265 (noting that signatories to the International Undertaking included "many developed countries that would not have signed a binding convention").

250. GRAIN has argued that the most serious intellectual property-related threat to developing countries is now occurring in WIPO, as the United States, the EC, and Japan press forward with negotiations for a new Substantive Patent Law Treaty (SPLT) that contains even fewer exceptions to patentability than does TRIPs. See GRAIN, One Global PATENT SYSTEM? WIPO'S SUBSTANTIVE PATENT LAW TREATY 5-6 (Oct. 2003), http://www.grain.org/docs/wipo-splt-2003-en.pdf [hereinafter GRAIN, ONE GLOBAL PATENT SYSTEM]. Although ratification of the SPLT is formally a matter left to each state's discretion, "in practice there would be considerable pressure on all WIPO members to join." Id. at 5. "Unlike some of the more specialized WIPO treaties, the SPLT will be so central to the future of the patent system-indeed, the power structures in the global economy-that it will be difficult to opt out." Id. 
(or at least not an immediate threat) to the hard law rules that could be generated in other venues. ${ }^{251}$

\section{Generating Counterregime Norms}

If developing countries sometimes use regime shifting strategically to shunt legal issues to the sidelines, they may also shift lawmaking initiatives into other regimes for very different instrumental reasons. Such shifts allow governments a "safe space" in which to analyze and critique those aspects of TRIPs that they find to be problematic. The institutions operating in these regimes act as settings for exchanging information among state and nonstate actors, for shaping interests and preferences, for defending existing treaty bargains or soft law understandings, and for developing proposals to revise or supplement existing intellectual property protection rules. ${ }^{252}$ When used in this way, regime shifting can be a potent method for creating counterregime intellectual property norms. ${ }^{253}$

Using regime shifting to produce counterregime norms also increases the likelihood that inconsistent legal rules will be adopted in different international fora. At first blush, the prospect of such divergences may seem unlikely, especially where all or most of the same states are involved in negotiations. But the trade and intellectual property specialists who negotiate in the WTO (where the United States and the EC are dominant) and in WIPO may have very different goals and incentives than the environmental and agricultural experts who represent governments in the COP and the CGRFA (where hegemonic influence is weaker or more closely aligned with the interests of developing states). ${ }^{254}$ The influence of NGOs and other nonstate actors is also likely to be different in different international regimes. This

251. That powerful governments are often aware that soft lawmaking initiatives can have hard edged consequences is shown by the resistance of the United States and, initially, the EC, to granting competence to the WHO to consider intellectual property issues. See supra Section III.C.

252. See Marc A. Levy et al., Improving the Effectiveness of International Environmental Institutions, in INSTITUTIONS FOR THE EARTH: SOURCES OF EFFECTIVE INTERNATIONAL PROTECTION 424 (Peter Haas et al. eds., 1993) (noting how even weak international organizations promote effective coordination among states through agenda setting, facilitating the negotiation of new initiatives, and enhancing national capabilities for compliance); George W. Downs et al., The Transformational Model of International Regime Design: Triumph of Hope or Experience?, 38 COLUM. J. TRANSNAT'L L. 465, 467-68 (2000) (describing and critically assessing the "transformation model" used to design multilateral regulatory institutions that "generate increasingly greater commitment and deeper cooperation through a process of iterative, state-to-state negotiation that promotes identity convergence"); see also CARY FowleR, UNNATURAL SELECTION: TECHNOLOgY, Politics, AND PLANT Evolution 180 (Int'l Stud. in Global Change, Vol. 6, 1994) (discussing how, in the 1980s, NGOs opposed to biodiversity-related intellectual property rights set out to "redefine[e] and repackage[e]" arguments and goals by addressing their concerns in FAO, "a new but potentially friendlier arena").

253. See supra Section II.B (discussing "counterregime norms").

254. See Abbott, Future of TRIPs, supra note 43, at 670 ("Some governments may send trade specialists to negotiate in the WTO, and IPRS specialists to negotiate in WIPO, and these negotiators may not speak with the same voice."); Dutfield, supra note 119, at 261 ("[N]ational delegations [to the COP] consist largely of civil servants from environment ministries. They tend to be concerned mostly about conservation, sustainable development and food security, and often have little contact with their trade ministry counterparts."); PETIT ET AL., supra note 128, at 50 (noting that mostly agriculture ministry officials represented governments in negotiations over the ITPGR); see also id. at 36 ("In the $\mathrm{CBD}$, the US delegation is at a disadvantage because the US Congress has not yet ratified the Convention and therefore the US is only an observer at the CBD."). 
creates opportunities for negotiating rules in one venue that would be unthinkable in another.

The legal inconsistencies generated by this type of regime shifting may be inadvertent, an unintended byproduct of addressing complex regulatory questions in multiple fora. Inconsistencies, in this view, are simply unfortunate accidents that can be remedied through more coherent approaches to lawmaking. ${ }^{255}$ But embedded in the very idea of counterregime norms is a more strategic understanding of legal inconsistencies, one in which states consciously create conflicts as a way to subvert the prevailing legal landscape and provide fuel for renegotiating principles, norms, and rules to reflect their interests more accurately. ${ }^{256}$ As I explain below, developing countries and NGOs used precisely this strategic approach in seeking to integrate the new rules developed in the biodiversity, PGR, public health, and human rights regimes into the WTO and WIPO.

\section{Integrating New Hard and Soft Law into the WTO and WIPO}

One important consequence of post-TRIPs regime shifting has been a sharp increase in intellectual property lawmaking in four international regimes, including two regimes (public health and human rights) not previously concerned with the products of human creativity or innovation. Such efforts can in themselves serve states' interests by creating new hard and soft law mechanisms (such as the access and benefit sharing rules of the ITPGR and the Bonn Guidelines) to achieve regime objectives weakened by the expansion of intellectual property rights. ${ }^{257}$ But in addition to these benefits, regime shifting can also function as an intermediate strategy that allows developing countries to generate the political groundwork necessary for new rounds of intellectual property lawmaking in the WTO and WIPO. When adopting this "integrationist" strategy, developing countries use regime

255. PETIT ET AL., supra note 128, at 6 (lamenting that the "multiplicity of interests and fora, and the existence of several debates or negotiations taking place simultaneously, can . . lead to poorly coordinated, inconsistent, and even contradictory policies"); $c f$. Marco C.E.J. Bronckers, More Power to the WTO?, 4 J. INT'L ECON. L. 41, 52 (2001) (chiding negotiators of Cartagena Protocol on Biosafety for failing to specify the Protocol's relationship to the WTO Agreements and urging treaty drafters "to resolve any divergences up front, rather than fuelling concerns about incompatible regimes").

256. Raustiala \& Victor, supra note 63 , at $37-38$ (discussing how states in the PGR regime create "strategic inconsistency" by crafting rules in one regime that are inconsistent with those in another). Cf. Joel P. Trachtman, The Domain of WTO Dispute Resolution, 40 HARV. INT'L L.J. 333, 34649 (1999) (arguing that states may deliberately leave treaty texts incomplete and stating that WTO Agreements are incomplete in that they do not "countenance the possibility of directly applicable norms from outside the WTO system") (footnote omitted) [hereinafter Trachtman, WTO Dispute Resolution].

257. In the PGR and biodiversity regimes, the treatment of genetic resources as the common heritage of humanity had been increasingly eroded during the 1980s and 1990s. Developing countries initially acquiesced in this erosion, in part because it allowed them to advocate alternative regime rules of national sovereignty, farmers' rights, and benefit sharing. See supra Section III.B. But none of these new rules could ensure revenue or technology flows to developing states or their nationals. So long as vast amounts of raw genetic material were freely available from international seed banks and so long as national intellectual property offices granted applications for patents and plant varieties based on genetic material obtained without prior informed consent, developing countries would see little financial benefit from plant-related innovations. Seen from this perspective, the ITPGR and Bonn Guidelines can be understood as attempts to create new legal mechanisms to provide monetary and technological gains to developing countries and their nationals. 
shifting to shore up support from hesitant allies, vet competing reform proposals, and generate common negotiating positions which they then introduce into the two organizations.

Several features of the post-TRIPs lawmaking environment have helped to foster this integrationist use of regime shifting. Consider first the consequences of confining counterregime intellectual property norms to venues other than the WTO and WIPO. As explained above, post-TRIPs intellectual property lawmaking occurring in the biodiversity, PGR, public health, and human rights regimes has mostly been of the soft law variety. Although declarations, resolutions, recommendations, and guidelines are nonbinding, they can serve as focal points for voluntary government conduct or templates for national legislation. The proliferation of biodiversity access laws by developing countries in response to recommendations by the COP exemplifies this influence of soft law on state behavior, as do nascent domestic efforts to protect traditional knowledge. ${ }^{258}$

But integrating soft lawmaking outside of the WTO and WIPO could have such an effect only for principles, norms, and rules that did not conflict with TRIPs. For TRIPs-inconsistent soft law, by contrast, voluntary government action or implementation into national laws would create a risk of exposure to WTO dispute settlement proceedings and WTO trade sanctions. In addition, soft law could have little impact where effective regulation of the problem required cross border harmonization (either upward or downward) of intellectual property protection standards that encompassed states opposed to such harmonization. ${ }^{259}$ For these reasons, translating many (albeit not all) counterregime norms into effective prescriptions for government action could not be achieved without amending TRIPs or introducing new treaty-making efforts in WIPO.

Integrating principles, norms, and rules generated in other regimes into the WTO and WIPO also offers considerable strategic advantages for developing countries. The WTO in particular facilitates package deals among a diverse array of regulatory topics, allowing these countries to exchange their reform proposals for concessions from industrialized states in other areas. They might, for example, agree to abandon demands to protect traditional knowledge in exchange for longer TRIPs transition periods or reduced trade barriers for their agricultural products and textiles. ${ }^{260}$ Tacit exchanges among

258. See supra note 128 (discussing the proliferation of national biodiversity access laws); infra note 306 (discussing non-treaty-based approaches for protecting traditional knowledge).

259. See The Relationship Between the TRIPs Agreement and the Convention on Biological Diversity and the Protection of Traditional Knowledge-Submission by Bolivia, Brazil, Cuba, Dominican Republic, Ecuador, India, Peru, Thailand, Venezuela, para. 20, WTO Doc. IP/C/W/403 (June 24, 2003) [hereinafter 2003 CBD Submission] ("National systems by themselves would not be adequate to fully protect and preserve traditional knowledge. For example, the ability of patent offices in national jurisdictions to prevent biopiracy as well as to establish informed consent mechanisms to ensure reward to TK holders, does not ipso facto lead to a similar action on the patent applications in other countries."); Philippe Cullet, Property Rights over Biological Resources: India's Proposed Legislative Framework, 4 J. WORLD INTELL. PROP. 211, 225 (2001) ("[D]eveloping countries will only be able to solve the [biopiracy] problems they are facing by obtaining limitations on the scope of patentability to be applied world-wide.").

260. See Dutfield, supra note 119, at 239 (suggesting that developing states may be using proposals to protect traditional knowledge in this strategic fashion). 
states are also possible within WIPO, although they are limited to trade-offs among different areas of intellectual property protection. ${ }^{261}$

But soft and hard law generated in the biodiversity, PGR, public health, and human rights regimes could serve as more than mere bargaining chips. They could, as well, function as a form of "regime borrowing" that enables developing states to achieve outcomes not attainable within each of the four regimes alone. ${ }^{262}$ First, any proposals adopted within the WTO could be enforced through its hard-edged enforcement mechanisms, which are far stronger than those of the other regimes. Second, negotiations in the WTO and WIPO would necessarily include the United States, which, by refraining from ratifying key biodiversity, PGR, and human rights treaties, ${ }^{263}$ has remained relatively impervious to the counterregime norms emanating from those regimes and thus free to pressure developing states to fully comply with TRIPs and to adopt TRIPs-plus standards. ${ }^{264}$

Finally, integrationist regime shifting enhances developing states' bargaining power within the WTO and WIPO. It facilitates a proactive negotiating strategy, enabling governments and NGOs to coordinate their efforts around hard and soft law proposals first vetted and refined in other international venues. This integrationist approach also allows states to justify their demands for reform by invoking rules and principles endorsed by officials of intergovernmental organizations and by legal and technical experts. Support from these seemingly neutral actors gives the demands the imprimatur of legitimacy. And it allows proponents to frame their arguments as rational efforts to harmonize potentially inconsistent treaty obligations and soft law standards that many states have agreed to, rather than as selfinterested attempts to distort trade rules or to free ride on foreign creators or inventors. Seen from this perspective, even the soft law intellectual property standards generated in the biodiversity, PGR, public health, and human rights regimes have hard-edged consequences. They act as the progenitors of proposals to revise legally binding rules within the WTO and WIPO.

\section{Overview of Rationales for Intellectual Property Regime Shifting}

Table 2 provides a simplified overview of the different (and sometimes competing) rationales underlying the use of intellectual property regime shifting in the biodiversity, PGR, public health, and human rights regimes.

261. Developing countries might, for example, accede to the EC's demands for a multilateral treaty to protect non-copyrightable databases in exchange for the EC's support of a treaty that protects traditional knowledge. Although such trade-offs may appear superficially attractive, they may well conflict with developing countries' long-term interests.

262. Leebron, supra note 33, at 14 (defining "regime borrowing" as utilizing "the institutional and procedural benefits" of one regime "when similar arrangements cannot be independently negotiated" within other regimes); see also supra note 58 (discussing regime borrowing).

263. The United States has signed but not ratified the CBD, the ICESCR, and the ITPGR. See David Shiman, Economic and Social Justice: A HuMan Rights PERSPECTIVE (Human Rights Res. Ctr., Topic Book 1), http://wwwl.umn.edu/humanrts/edumat/hreduseries/tblb/Section 1/tbl $-3 . \mathrm{htm}$ (discussing ICESCR); U.S. Mission to Italy, U.S. Signs the International Treaty on Plant Genetic Resources for Food and Agriculture, at http://www.usembassy.it/usunrome/files/Statements/ A2111209.htm (discussing ITPGR); Raustiala, supra note 118, at 492-94 (discussing CBD).

264. See supra note 10 (discussing "TRIPs-plus" agreements). 


\section{TABLE 2. RATIONALES FOR INTELlECtUAL PROPERTY REgIME SHIFTING}

\begin{tabular}{|c|c|c|c|c|}
\hline & Biodiversity & PGRs & Public Health & Human Rights \\
\hline $\begin{array}{l}\text { Predominant } \\
\text { Rationale for } \\
\text { Post-TRIPs } \\
\text { Regime Shifting } \\
\text { by Developing } \\
\text { Countries and } \\
\text { NGOs }\end{array}$ & $\begin{array}{l}\text { Laboratories to } \\
\text { maximize desired } \\
\text { policy outcomes } \\
\text { (e.g., controlling } \\
\text { access to national } \\
\text { biodiversity and } \\
\text { protecting } \\
\text { traditional } \\
\text { knowledge) }\end{array}$ & $\begin{array}{l}\text { Laboratories to } \\
\text { maximize desired } \\
\text { policy outcomes } \\
\text { (e.g., facilitating } \\
\text { access to PGRs in } \\
\text { international seed } \\
\text { banks in exchange } \\
\text { for benefit } \\
\text { sharing) }\end{array}$ & $\begin{array}{l}\text { Integrating new } \\
\text { principles, norms, } \\
\text { and rules into the } \\
\text { WTO and WIPO } \\
\text { (e.g., greater } \\
\text { access to patented } \\
\text { medicines) }\end{array}$ & $\begin{array}{l}\text { Generating } \\
\text { counterregime } \\
\text { norms (e.g., } \\
\text { granting primacy } \\
\text { to human rights } \\
\text { obligations over } \\
\text { trade and IP } \\
\text { agreements) }\end{array}$ \\
\hline $\begin{array}{l}\text { Subsidiary } \\
\text { Rationale for } \\
\text { Post-TR̂IPs } \\
\text { Regime Shifting } \\
\text { by Developing } \\
\text { Countries and } \\
\text { NGOs }\end{array}$ & $\begin{array}{l}\text { Integrating new } \\
\text { principles, norms, } \\
\text { and rules into the } \\
\text { WTO and WIPO } \\
\text { (e.g., new } \\
\text { disclosure rules } \\
\text { for biodiversity } \\
\text { patents and } \\
\text { protecting } \\
\text { traditional } \\
\text { knowledge) }\end{array}$ & $\begin{array}{l}\text { Creating safety } \\
\text { valves (e.g., } \\
\text { protecting } \\
\text { farmers' rights and } \\
\text { traditional } \\
\text { knowledge) }\end{array}$ & $\begin{array}{l}\text { Generating } \\
\text { counterregime } \\
\text { norms (e.g., } \\
\text { opposition to } \\
\text { "TRIPs-plus" } \\
\text { treaties) }\end{array}$ & $\begin{array}{l}\text { Laboratories to } \\
\text { maximize desired } \\
\text { policy outcomes } \\
\text { (e.g., protecting } \\
\text { rights of } \\
\text { indigenous } \\
\text { peoples and } \\
\text { traditional } \\
\text { knowledge) }\end{array}$ \\
\hline
\end{tabular}

\section{Hegemonic Responses to Regime Shifting by Developing States}

As this table reveals, the many hard and soft lawmaking initiatives that developing countries and NGOs have pursued in the four international regimes provide evidence to support each of the regime shifting rationales discussed in the previous subsections. Yet an important puzzle remains: why would the United States and the EC permit developing countries to engage in such moves?

One answer may be that some powerful states support regime shifting because it serves their own interests. In the post-TRIPs lawmaking environment, the clear legal fault lines that divided North from South during the Uruguay Round are slowly beginning to erode. Developing country governments are sometimes divided amongst themselves over intellectual property issues. ${ }^{265}$ And, as explained in greater detail below, reform proposals are beginning to receive support from some industrialized states, especially in Europe. ${ }^{266}$ Where these new negotiating alliances emerge, they make it more

265. See, e.g., Seven WTO Nations Oppose Added Protection for Geographical Indications for New Items, 19 Int'l Trade Rep. (BNA), No. 32, at 1386 (Aug. 8, 2002) (discussing divisions among developing countries over need for greater protection for geographical indications); Drahos, Developing Countries, supra note 8, at 782 (stating that "[s]ome intellectual property issues will divide rather than unite developing countries," citing the ban on patenting of life forms and geographical indications as examples); PETIT ET AL., supra note 128, at 25-32 (discussing divergent approaches to regulating plant genetic resources in Brazil, India, Kenya, and the Philippines).

266. See, e.g., U.S. Seen Losing Ground in Latest Draft of Reform Proposal on TRIPS/Medicines, 19 Int'l Trade Rep. (BNA), No. 50, at 2162 (Dec. 19, 2002) (discussing support by European Union, Japan, and other developed states-but not the United States-for a proposal to give developing countries "more leeway to issue compulsory licenses for the import of cheaper generic medicines"); GRAIN, Response to the Open Letter to Pascal Lamy on TRIPs Article 27.3(b) Review, 
difficult for other powerful nations such as the United States to oppose regime shifting.

A second answer may be that states have different (and sometimes inaccurate) perceptions of why other nations are engaging in regime shifting. Powerful states may acquiesce in or even endorse regime shifting by developing countries, believing that it will act as a safety valve that placates transnational advocacy networks or domestic interest groups or shifts attention away from treaty-making in other fora. Yet these same moves may create opportunities for weaker states to generate counterregime norms-norms that in their early soft law iterations pose little threat to the dominant legal order but that serve as seeds for more consequential revisions of intellectual property protection standards. That multiple rationales may support a single instance of regime shifting suggests that post-TRIPs intellectual property lawmaking is becoming more complex. The next part explores one important aspect of that complexity-the integration of new intellectual property principles, norms, and rules from the biodiversity, PGR, public health, and human rights regimes into the WTO and WIPO.

\section{EMPIRICAL SUPPORT FOR AN INTEGRATIONIST REGIME SHIFTING STRATEGY}

Substantial empirical evidence supports the existence of an integrationist intellectual property regime shifting strategy by developing states. In particular, these states have used different "entry points" in the WTO and WIPO to leverage proposals into the two organizations that they had helped to create in other international regimes. A principal argument advanced to support these proposals was the claim that TRIPs was inconsistent with the principles, norms, and rules in other issue areas. As described in the following chronological overview, these proposals have encountered different levels of resistance from industrialized countries.

\section{A. TRIPS Article 27.3(b) and the Seattle Ministerial Conference}

Developing country governments first introduced proposals to harmonize TRIPs with the rules developed in other international regimes during the review of TRIPs Article 27.3(b). That article contains a limited obligation to grant intellectual property rights in life forms. It mandates patent protection for microorganisms and for non-biological and microbiological

http://www.grain.org/publications/lamy-response-en.cfm (Mar. 26, 2003) ("The EU is, together with Norway, the only industrialized [WTO] member which has been responsive to concerns expressed by developing countries on the interplay between the TRIPs Agreement and the Convention on Biodiversity. Other industrialized countries have constantly downplayed this issue."). See also supra note 195 and infra note 289 and accompanying text (discussing European support of developing country governments' proposals relating to public health and biodiversity). It is premature, of course, to predict whether these new alliances will lead to a revision of intellectual property protection standards in the WTO or WIPO. See Jeffrey L. Dunoff, Mission Impossible: Resolving the WTO's Trilemma 13-14 (2003) (unpublished manuscript on file with The Yale Journal of International Law) (arguing that although developing states are increasingly active in the Doha round of trade negotiations, "whether this activity will translate into an enhanced quality of participation at the WTO (i.e. more favorable outcomes) is, at this point, an open question"). 
processes for the production of plants or animals, and patent and/or sui generis protection for plant varieties. ${ }^{267}$ Given the controversial nature of these obligations, however, WTO negotiators agreed to review them in 1999, "four years after the date of entry into force of the WTO Agreement." 268 The TRIPs Council commenced that review in late 1998, but negotiations were transferred to the WTO General Council as members prepared for the Ministerial Conference held in Seattle in December 1999.

Developing states capitalized on these two review opportunities to introduce numerous jointly authored proposals to amend TRIPs. These proposals expressly relied on events occurring in the biodiversity and PGR regimes to support TRIPs revisions that would allow WTO members to (1) harmonize intellectual property rules with those generated within the CBD and $\mathrm{FAO}$; (2) deny patent protection to inventions inconsistent with the CBD; (3) protect traditional knowledge; and (4) ensure the TRIPs-compatibility of national laws protecting farmers' rights. ${ }^{269}$ In all, "almost 100 developing countries signed onto a near dozen proposals to reform TRIPs as far as biodiversity and indigenous knowledge were concerned." 270

After WTO members failed to agree on a new round of trade negotiations in Seattle, developing countries' efforts to amend Article 27.3(b) became more assertive and more detailed. ${ }^{271}$ Their proposals identified

267. TRIPs, supra note 1, art. 27(1) , 27.3(b), 33 I.L.M. at 97-98 (specifying patentable subject matter and exclusions and providing that WTO "Members may also exclude from patentability . . . plants and animals other than microorganisms; and essentially biological processes for the production of plants or animals other than non-biological and microbiological processes. However, Members shall provide for the protection for plant varieties either by patents or by an effective sui generis system or by any combination thereof.").

268. Id. For a detailed discussion of Article 27.3(b) and its unique position in TRIPs, see HELFER, IPRS IN PLANT VARIETIES, supra note 38, at 22-24.

269. See, e.g., Preparations for the 1999 Ministerial Conference-Proposal on Protection of the Intellectual Property Rights Relating to the Traditional Knowledge of Local and Indigenous Communities-Communication from Bolivia, Colombia, Ecuador, Nicaragua, and Peru, paras. 9-10, WTO Doc. WT/GC/W/362 (Oct. 12, 1999) [hereinafter Bolivia et al. Communication] (advocating studies and later negotiation of a "multilateral legal framework" to protect traditional knowledge consistent with CBD Article 8(j)); Preparations for the 1999 Ministerial Conference, The TRIPs Agreement-Communication from Kenya on Behalf of the African Group, para. 23, WTO Doc. WT/GC/W/302 (Aug. 6, 1999) [hereinafter African Group Proposal] (advocating amendment to Article 27.3(b) to clarify that "any sui generis law for plant variety protection can provide for . . the protection of the innovations of indigenous and local farming communities in developing countries, consistent with the [CBD] and the International Undertaking"); Proposals Regarding the TRIPS Agreement in Terms of Paragraph 9(a)(i) of the Geneva Ministerial Declaration-Communication from India, para. 4, WTO Doc. WT/GC/W/225 (July 2, 1999) ("It is widely agreed that the TRIPS Agreement is incompatible with the Convention on Biodiversity. There is first need therefore to incorporate a provision that patents inconsistent with Article 15 of the CBD must not be granted."); Proposals Regarding the TRIPS Agreement in Terms of Paragraph 9(a)(i) of the Geneva Ministerial Declaration-Communication from Venezuela, para. II.1, WTO Doc. WT/GC/W/282 (Aug. 6, 1999) [hereinafter Venezuela Communication] (seeking to include "the principles" of CBD in TRIPs and supporting India's proposal "to prohibit the granting of patents to those inventions made with foreign genetic material that are inconsistent with Article 15 of the CBD relating to the recognition of sovereignty and access to genetic resources"). For a summary of all proposals, see GRAIN, For a Full Review of TRIPs 27.3(b): An Update on Where Developing Countries Stand with the Push To Patent Life at WTO, Annex, at http://www.grain.org/publications/tripsfeb00-en-p.htm (Mar. 2000).

270. GRAIN, supra note 269 , section 4 .

271. Brazil's proposal to amend Article 27.3(b) to allow states to impose additional conditions on patent protection to police the CBD's informed consent and benefit sharing objectives is a notable 
specific legal inconsistencies and argued that TRIPs amendments were necessary to avoid conflicts among international regimes. ${ }^{272}$ But negotiations remained deadlocked by fundamental disagreements. Industrialized country governments denied the existence of any inconsistencies, ${ }^{273}$ and sought to raise TRIPs standards and narrow exemptions, whereas developing country governments argued for an expansion of their discretion to achieve the objectives of other regimes. ${ }^{274}$

\section{B. The Doha Round and the Cancún Ministerial Meeting}

Negotiations over PGRs, biodiversity, and traditional knowledge were also affected by the growing global crisis over HIV/AIDS. ${ }^{275}$ Developing countries responded to the crisis by adopting an integrationist negotiating

example. Review of Article 27.3(b)-Communication from Brazil, para. 25, WTO Doc. IP/C/W/228 (Nov. 24, 2000) [hereinafter Brazil Communication]. The Brazil Communication noted that:

Brazil considers that Article 27.3(b) should be amended in order to include the possibility of Members requiring, whenever appropriate, as a condition to patentability: (a) the identification of the source of the genetic material; (b) the related traditional knowledge used to obtain that material; (c) evidence of fair and equitable benefit sharing; and (d) evidence of prior informed consent.

Id. Brazil cited to specific provisions of the CBD and national laws implementing the treaty, noted the potential for conflicts at "the implementation level" between TRIPs and the CBD, and disputed arguments raised by the United States challenging the practicality of its proposal. Id. paras. 19-27. See also Communication from India, para. 16, WTO Doc. IP/C/W/195 (July 12, 2000) (advocating amendment of TRIPs Article 29 to require "a clear mention of the biological source material and the country of origin"); Review of the Provisions of Article 27.3(b)-Communication from Mauritius on Behalf of the African Group, para. 5.4, WTO Doc. IP/C/W/206, (Sept. 20, 2000) (stating that the "TRIPs Agreement should contain provisions to promote and not undermine the conservation and sustainable use of genetic material, and to prevent the associated biopiracy").

272. See, e.g., Brazil Communication, supra note 271, para. 24 (discussing conflicts between CBD and TRIPs "at the implementation level"); see also Pires de Carvalho, supra note 121, at 379-401 (arguing that proposals requiring disclosure of origin or evidence of prior informed consent as a condition for granting biodiversity-related patent applications are inconsistent with TRIPs and identifying TRIPs-compatible alternatives).

273. Review of the Provisions of Article 27.3(b) -Japan's View, at 6, WTO Doc. [P/C/W/236, (Dec. 11, 2000) [hereinafter Japan's View] ("It is the view of Japan that the TRIPs Agreement and the CBD are mutually non-exclusive. Because of the totally different objectives and the flexibility of the provisions of the two treaties, it would be unlikely that one would conflict with the other when implemented."); Review of the Provisions of Article 27.3(b) of the TRIPs Agreement-Communication from the European Communities and their Member States, para. 12, WTO Doc. IP/C/W/254 (June 13, 2001) [hereinafter EC Communication] (stating that "there is nothing in the provisions of either agreement that would prevent a state from fulfilling its obligations under both"); Review of the Provisions of Article 27.3(b)-Further Views of the United States, at 5, WTO Doc. IP/C/W/209 (Oct. 3, 2000 ) (arguing that national access laws and MTAs are superior ways to implement the CBD and that therefore there is "no need to consider amending the provisions of either agreement to accommodate the implementation of the other").

274. See Dutfield, supra note 119 , at 270-73 (reviewing competing proposals).

275. Concern over the intellectual property aspects of the HIV/AIDS crisis arose as a result of legal challenges by pharmaceutical companies and the United States to compulsory license and local working rules enacted by South Africa and Brazil to reduce the price and increase the distribution of patented medicines to treat the disease. See CORREA, IMPLICATIONS, supra note 204, at 1-2; Sell, Access to Medicines, supra note 8, at 495-96, 500-02. Both challenges were withdrawn largely as a result of an organized campaign by public health NGOs which successfully argued that the enforcement of intellectual property rights was impeding public health objectives. See Brazil-US Reach Agreement in IPR Dispute, 5 BRIDGES WEEKLY TRADE NEwS Digest (Int'l Ctr. for Trade and Sustainable Dev., Geneva, Switz.), June 26, 2001; Drug Companies Drop Case Against S. African Government, 5 BRIDGES WEEKLy TRADE News Digest (Int'l Ctr. for Trade and Sustainable Dev., Geneva, Switz.), Apr. 24, 2001. 
strategy, relying on proposals generated in the WHO and the U.N. human rights system to infuse public health concerns into the WTO. ${ }^{276}$ In April 2001, a coalition of fifty-eight developing countries proposed that the TRIPs Council hold a special session devoted to access to medicines. Their intention, according to the representative from Zimbabwe, was "to bring into this Council an issue that has aroused public interest and is being actively debated outside this organisation, but one which we cannot afford to ignore." ${ }^{, 277}$ In a document distributed prior to the June 2001 meeting, the coalition cited to resolutions in other international fora (and to policy papers by NGOs) to support a clarification of TRIPs-compatible options to enhance access to medicines. ${ }^{278}$ This document served as the template for negotiating the Public Health Declaration, adopted at the November 2001 Doha Ministerial Conference. $^{279}$

In the two years following the conference, WTO members introduced competing proposals to carry out the Public Health Declaration's objective of facilitating exports of generic drugs to poor countries with insufficient domestic pharmaceutical manufacturing capacity. ${ }^{280}$ Many developing states urged that TRIPs be amended to permit such exports to any such country that experiences a public health emergency. ${ }^{281}$ The United States initially offered strident resistance to this amendment, proffering instead a proposal that was restricted both in terms of the diseases it covered and the countries it allowed to import generic medicines. ${ }^{282}$ Although WTO members were unable to reach agreement by the end of 2002 as required by the Declaration, on the eve of the

276. In addition to the work of the WHO and the U.N. human rights bodies discussed in detail above-see supra Sections III.C \& III.D-statements promoting access to and affordability of medicines were also adopted in several other U.N. sessions and documents. See Further Initiatives for Social Development, Res. S-24/2, U.N. GAOR, Special Sess. on Soc. Dev. para. 101 (2000) (recognizing "the critical importance of access to essential medicines at affordable prices," and stating "that Member States may freely exercise, consistent with national laws and international agreements acceded to, in an unrestricted manner, the options available to them under international agreements to protect and advance access to life-saving, essential medicines"); February 2001 Report of the Secretary General, para. 101, U.N. Doc. A/55/779 (2001) (urging states to "find ways of more effectively using trade policy provisions, such as compulsory licensing or parallel importation, to increase access to care" and expand access to low-cost generic drugs); Jennifer Steinhauer, U.N. Redefines AIDS as Political Issue and Peril to Poor, N.Y. TIMES, June 28, 2001, at A1 (describing a U.N. General Assembly declaration calling upon all countries "to develop national strategies for combating the spread of H.I.V. and to provide treatment for all those infected").

277. Statement by Zimbabwe to the WTO TRIPs Council (Apr. 5, 2001), reprinted in 't Hoen, supra note 188 , at $38 \mathrm{n} .38$.

278. Submission by the African Group et al., paras. 7-14, WTO Doc. IP/C/W/296 (June 29, 2001) (noting that whereas the TRIPs Council "has only recently begun to discuss the implications of the TRIPs Agreement to public health, other intergovernmental organizations and civil society have already been paying careful attention to such implications for some time," citing to developments discussed in note 276 supra).

279. See Abbott, Doha Declaration, supra note 196, at 484 (noting that "most of the key concerns" addressed in the developing states' proposals are reflected in the Public Health Declaration).

280. Public Health Declaration, supra note 12, para. 6 (recognizing that "WTO Members with insufficient or no manufacturing capacities in the pharmaceutical sector could face difficulties in making effective use of compulsory licensing" and instructing the TRIPs Council "to find an expeditious solution to this problem" before the end of 2002).

281. See Council for TRIPs, Proposals on Paragraph 6 of the Doha Declaration on the TRIPs Agreement and Public Health: Thematic Compilation, at 16, WTO Doc. IP/C/W/363 (2002).

282. TRIPs and Health Talks Deadlock in the WTO as U.S. Takes Hard Line, INSIDE U.S. TRADE, Nov. 29, 2002. 
September 2003 ministerial meeting in Cancún, Mexico, they adopted an interpretive decision that allows any WTO member to manufacture and export patented medicines pursuant to a compulsory license to any "eligible importing member." 283 The details of this decision are both complex and technical, and include several side statements in which specific countries have unilaterally agreed to refrain from acting either as importers or as exporters. ${ }^{284}$ Distilled to its essence, however, the decision allows developing countries that lack sufficient domestic manufacturing capacity to meet their public health needs by importing generic drugs from other WTO members without restriction as to type of disease or type of emergency.

The Public Health Declaration and the negotiations it spawned are the most well-known results of the Doha meetings. But the Doha Ministerial Declaration's treatment of biodiversity and traditional knowledge also reveals an integrationist regime shifting strategy. In particular, paragraph nineteen of the Declaration directs the TRIPs Council to examine "the relationship between [TRIPs] and the [CBD], the protection of traditional knowledge and folklore, and other relevant new developments raised by Members," taking into account the "development dimension." 285

Developing countries invoked this mandate and seized the reform initiative following the April 2002 adoption of the Bonn Guidelines by the CBD's COP, which recommended using patent applications to police compliance with CBD's access and prior informed consent rules. In June 2002, eleven developing states submitted a detailed proposal to amend TRIPs to give effect to the Guidelines and to "prevent systematic conflicts with the CBD arising from the implementation of TRIPS." ${ }^{286}$ Whereas earlier harmonization proposals merely granted states the discretion to enact biodiversity-related patent disclosure requirements, the 2002 proposal adopts a more aggressive mandatory approach. It seeks to compel all WTO members to require applicants for patents relating to biological materials and traditional

283. Council for TRIPS, Implementation of Paragraph 6 of the Doha Declaration on the TRIPS Agreement and Public Health (2003), http://www.wto.org/english/tratop_e/trips_e/ implem_para6_e.htm.

284. See Press Release, World Trade Organization, General Council Chairperson's Statement (Aug. 30, 2003), http://www.wto.org/english/news_e/news03_e/trips_stat_28aug03_e.htm (placing on the record a statement representing "several key shared understandings of Members regarding the Decision to be taken and the way in which it will be interpreted and implemented," including countries agreeing to opt out or restrict imports or exports of pharmaceuticals).

285. Doha Ministerial Declaration, supra note 13, para. 19. In carrying out this work, paragraph 19 directs the TRIPs Council to "be guided by the objectives and principles set out in Articles 7 and 8 of the TRIPs Agreement." Id. Article 7 emphasizes that the protection and enforcement of intellectual property rights "should contribute to the promotion of technological innovation and to the transfer and dissemination of technology ... in a manner conducive to social and economic welfare, and to a balance of rights and obligations." Article 8 permits members to "adopt measures necessary to protect public health and nutrition, and to promote the public interest in sectors of vital importance to their socio-economic and technological development." TRIPs, supra note 1, arts. 7, 8, 33 I.L.M. at 8687. The reference to these articles reaffirms that TRIPs permits WTO members to adopt balanced systems of intellectual property protection.

286. The Relationship Between the TRIPs Agreement and the Convention on Biological Diversity and the Protection of Traditional Knowledge, para. 11, WTO Doc. IP/C/W/356 (2002). 
knowledge to disclose certain information as a condition of obtaining legal protection. $^{287}$

Although industrialized states initially opposed the creation of additional patent disclosure rules, ${ }^{288}$ the EC and Switzerland responded to the developing states' proposal with a compromise. The EC response calls for negotiation of "a self-standing disclosure requirement," that, while not functioning as a new eligibility criterion for patent protection, "would allow Members to keep track, at [the] global level, of all patent applications with regard to genetic resources for which they have granted access." ${ }^{289}$ In June 2003, developing countries rejected the compromise ${ }^{290}$ and "reaffirm[ed] and strengthen[ed] their demand for a strong disclosure of origin mechanism" within TRIPs that would require "not only detailed information about who provided the [genetic] materials or the [traditional] knowledge used [in patent applications], but also positive proof of benefit sharing and of prior informed consent. ${ }^{, 291}$ African countries also proposed a new "Decision on Traditional Knowledge" to be incorporated into TRIPs. ${ }^{292}$

The fate of these competing proposals was cast into doubt by the collapse of trade talks at the Cancún ministerial meeting in September 2003. The breakdown, while not as severe as that which occurred in Seattle in 1999, has considerably slowed the pace of negotiations and (with the exception of the decision on patented medicines) may even cast into doubt the successful conclusion of the Doha Round. Observers are divided over which governments bear the blame for the rift, but all agree that developing countries were far more organized and cohesive at Cancún than at previous trade meetings. ${ }^{293}$ Indeed, the Cancún meeting saw the emergence of a new negotiating block-the so-called "Group of 21" developing states-that forcefully advanced the interests of poorer WTO members, often with the

287. Id. para. 10.

288. See supra note 263 (discussing opposition by the United States, Japan, and the EC).

289. European Commission Directorate-General for Trade, Communication by the European Communities and their Member States to the TRIPs Council on the Review of Article 27.3(b) of the TRIPs Agreement, and the Relationship Between the TRIPs Agreement and the Convention on Biological Diversity (CBD) and the Protection of Traditional Knowledge and Folklore: "A Concept Paper," paras. 51, 55 (Sept. 12, 2002) [hereinafter EC Concept Paper]. The Swiss proposal to the TRIPs Council, although eschewing any amendment of TRIPs, would "enable the national patent legislation to require the declaration of the source of genetic resources and traditional knowledge in patent applications" by seeking in WIPO an amendment to the Patent Cooperation Treaty and the Patent Law Treaty. See Review of Article 27.3(b), the Relationship Between the TRIPs Agreement and the Convention on Biological Diversity, and the Protection of Traditional Knowledge-Communication from Switzerland, at 1, WTO Doc. IP/C/W/400/Rev.1 (June 18, 2003).

290. Taking Fonward the Review of Article 27.3(b) of the TRIPs Agreement-Joint Communication from the African Group, at 4-6, WTO Doc. IP/C/W/404 (June 26, 2003) [hereinafter 2003 Africa Group Communication] (defending several proposals to amend TRIPs to prevent misappropriation of genetic resources and protect traditional knowledge); 2003 CBD Submission, supra note 259, para. 3 ("The purpose of this present submission is to highlight and strengthen the principal arguments for inserting a provision in the TRIPS Agreement that mandates" CBD-inspired patent disclosures.).

291. GRAIN, The TRIPS ReVIEW AT A TURning PoINT? 1 (July 2003), http://www.grain.org/ docs/trips-july-2003-en.pdf.

292. See 2003 Africa Group Communication, supra note 290, at 7-9.

293. See The WTO Under Fire: Why Did the World Trade Talks in Mexico Fall Apart? And Who Is To Blame?, ECONOMIST, Sept. 20, 2003, at 26-28. 
support of NGOs. ${ }^{294}$ Whether these countries will be effective at moving the talks forward remains to be seen. Walk-outs, delays, and threats of collapse are endemic to multilateral trade negotiations and they may become even more prevalent as weaker states use regime shifting to bolster their common negotiating positions.

\section{WIPO Patent Treaties and the Intergovernmental Committee on Intellectual Property, Genetic Resources, Traditional Knowledge and Folklore}

While these events were unfolding at the WTO, developing countries also focused their attention on WIPO, using two entry points to integrate rules generated in other international regimes into the organization: (1) the negotiation of two multilateral patent agreements, the Patent Law Treaty (PLT) ${ }^{295}$ and the Substantive Patent Law Treaty (SPLT); ${ }^{296}$ and (2) the creation of a new Intergovernmental Committee on Intellectual Property and Genetic Resources, Traditional Knowledge and Folklore (IGC). ${ }^{297}$

Developing states first sought to link biodiversity issues to the WIPOsponsored negotiation of the PLT in 1999. They proposed the addition of an article to the treaty requiring applicants for inventions derived from genetic resources to demonstrate that they had received from the country of origin permission to access those resources. ${ }^{298}$ Industrialized country governments opposed the proposal, arguing that it addressed substantive law matters that were inappropriate for inclusion in a treaty largely devoted to procedural issues. ${ }^{299}$ After several rounds of consultations and meetings, ${ }^{300}$ the WIPO

294. Id. at 27.

295. The PLT, adopted June 1, 2000, harmonizes the procedures that national patent officers use to administer patent applications. Patent Law Treaty, 39 I.L.M. 1047, http://www.wipo.int/clea/docs/en/wo/wo038en.htm\#P268_43807. The treaty defines a single set of rules for preparing, filing and managing patents in all signatory countries. Id. arts. 5-14, at 1051-59. The PLT will enter into force after ten states have ratified it. Id. art. 21, at 1063-64. As of October 15, 2003, only seven nations had ratified the treaty. WIPO, Actions in Respect of Treaties Administered by WIPO Not Yet in Force: Patent Law Treaty, http://www.wipo.org/treaties/documents/english/pdf/u-page34.pdf (Oct. 15, 2003).

296. The SPLT seeks to harmonize substantive patent law issues such as patentable subject matter, exclusions, and the first to file rule. GRAIN, World Patent System, supra note 107, at 2-3. The treaty is currently the subject of negotiations among government representatives under WIPO's auspices. See GRAIN, ONE GlOBAL PATENT SYSTEM, supra note 250.

297. For a detailed review of the IGC's work and supporting documents, see WIPO, Traditional Knowledge and Cultural Expressions, at http://www.wipo.org/globalissues/index.html (last visited Dec. 18, 2003). For an explanation of why developing countries would wish to integrate counterregime noms into WIPO as well as into the WTO, see supra Section II.D (discussing the continuing importance of WIPO in post-TRIPs lawmaking environment).

298. See Intellectual Property and Genetic Resources: An Overview-Meeting on Intellectual Property and Genetic Resources, para. 1, WIPO Doc. WIPO/IP/GR/00/2 (Mar. 24, 2000) [hereinafter: Intellectual Property and Genetic Resources] (reproducing text of proposal by Colombia); WIPO, Standing Comm. on the Law of Patents, 3d Sess., paras. 25, 202 WIPO Doc. SCP/3/11 (1999) (reporting support for Colombia's proposal by thirteen developing states).

299. WIPO, Standing Comm. on the Law of Patents, supra note 298, para. 205 (noting opposition by, inter alia, the United States, the EC, Japan, South Korea, and Romania).

300. See id. para. 208; Intellectual Property and Genetic Resources, supra note 297, para. 34 (concluding that issues relating to intellectual property and genetic resources "are not clearly understood" and that "there is an urgent need for such work to be undertaken" by WIPO). 
Secretariat endorsed the creation of a "distinct body" to address the intellectual property aspects of resources and traditional knowledge, issues that it noted had assumed increasing importance in other international regimes. ${ }^{301}$

When the WIPO General Assembly approved the Secretariat's proposal in September 2000, forty developing countries (as well as several industrialized states) spoke in favor of the IGC. ${ }^{302}$ They stated that the IGC's work could provide significant economic and social benefits to developing countries by modifying intellectual property rules to protect genetic resources and traditional knowledge. ${ }^{303}$ They also emphasized the need for WIPO to coordinate but not supplant the treatment of these issues in other international regimes. ${ }^{304}$ Finally, several developing nations stressed the importance of depoliticizing discussions (presumably a veiled reference to the contentious debates then underway at the WTO over the same issues) and of inviting NGOs to participate in the IGC's work. ${ }^{305}$

During the IGC's first five sessions between April 2001 and July 2003, developing states have continued to support a wide-ranging work program for the Committee, including: (1) creating a searchable database of contractual clauses in MTAs governing access to genetic resources and benefit-sharing; (2) studying technical issues raised by the disclosure of biodiversity-related information in patent applications; (3) creating databases of traditional knowledge; (4) identifying ways to document traditional knowledge in the public domain; and (5) debating the appropriate legal rules to protect traditional knowledge, including sui generis systems. Many of these

301. WIPO General Assembly, Matters Concerning Intellectual Property and Genetic Resources, Traditional Knowledge and Folklore, 26th (12th Extraordinary) Sess., paras. 2, 10, WIPO Doc. WO/GA/26/6 (2000) (noting relevance of these issues to "food and agriculture, biological diversity and the environment, biotechnology innovation and regulation, human rights, cultural policies and trade and economic development").

302. See WIPO General Assembly, Report of the Twenty-Sixth (12th Extraordinary) Session, Geneva, Sept. 25 - Oct. 3, 2000, WIPO Doc. WO/GA/26/10 (2000) [hereinafter WIPO Assembly Report]. Japan and France also supported the new committee, although with some hesitation. See id.

303. Id. para. 45 (delegation of Tanzania stating that "there was a huge potential of social and economic benefits for developing and least-developed countries if proper intellectual property protection was accorded to genetic resources, traditional knowledge and expressions of folklore"); id. para. 52 (delegation of Nigeria expressing concern that "the present approach and attitude to genetic resources, traditional knowledge and folklore stemmed from a limited and perhaps restrictive interpretation of intellectual property, further exacerbated by the TRIPS regime" and emphasizing the need for "a more liberal definition of intellectual property rights"). See id. para. 46 (delegation of Kenya noting the country's "wealth in genetic resources and traditional knowledge").

304. Id. para. 30 (delegation of Dominican Republic, on behalf of the Group of Countries of Latin America and the Caribbean, noting that support for the IGC was "not an attempt to replace consideration of these questions in any other multilateral fora where they might be analyzed, negotiated upon, or discussed"); id. para. 33 (delegation of Bulgaria, on behalf of the Central European and Baltic States Group, noting that "the subject matter under consideration was not a new issue as it has already been on the agenda of different organizations and ... the record of activities in this field was substantial"); id. para 47 (delegation of Brazil noting that other international bodies had asked WIPO to "play a meaningful role in international debates on intellectual property and genetic resources, traditional knowledge and folklore"); id. para. 54 (delegation of Bangladesh urging WIPO to "work closely with other international agencies" to create "a new global regime" on these issues).

305. Id. paras. 38, 46, 47 (delegations of Egypt, Kenya, and Brazil noting the need to depoliticize discussions); id. paras. 32, 46 (delegations of Malaysia and Kenya proposing inviting relevant international organizations and NGOs to participate as observers at the IGC meetings). 
undertakings respond directly to initiatives first proposed by developing countries in the CBD's COP. ${ }^{306}$ Most recently, the WIPO General Assembly extended the Committee's mandate and authorized it to accelerate its work, which may include the development of new international instruments. ${ }^{307}$

Whereas the IGC has thus far emphasized soft law studies and reports, governments are also debating biodiversity, PGR, public health, and traditional knowledge issues in hard law negotiations over the SPLT. ${ }^{308}$ They have also asked the WIPO Secretariat to review the implications of the SPLT for the IGC's future work, ${ }^{309}$ a request that illustrates their increasing recognition of the need to coordinate lawmaking not only across different regimes, or across venues within a conglomerate regime, but also in different fora within the same intergovernmental organization.

\section{REgIME SHIFTING AND NEW DYNAMICS OF INTELLECTUAL PROPERTY LAWMAKING AND DISPUTE SETTLEMENT}

Regime shifting is in itself a noteworthy feature of international relations. It demonstrates an acute awareness by government officials, international secretariats, and nonstate actors of the fluidity of lawmaking processes, and reveals such actors' keen ability to assess the comparative institutional advantages offered by different negotiating fora for achieving particular goals. Intellectual property provides an especially apt case study to assess the legal and political consequences of regime shifting. States and NGOs have focused their strategic maneuvering on a dense and highly contested issue area of international relations and, in a very short time period, have begun to alter the principles, norms, and rules of intellectual property protection and the decision-making procedures by which those prescriptions are generated.

306. See Press Release, WIPO, IGC Moves Ahead on Traditional Knowledge Protection, WIPO Doc. PR/2002/317 (June 25, 2002) [hereinafter IGC Moves Ahead] (discussing work undertaken by the IGC); WIPO Committee: Countries Divided on Need for and Scope of Legal System To Protect TK, BRIDGES TRADE BIoRes (Int'l Ctr. for Trade and Sustainable Dev., Geneva, Switz.), June 27, 2002 (discussing various proposals by developing countries to protect traditional knowledge based on recommendations adopted by COP). See also supra Section III.A. (reviewing intellectual property lawmaking by COP).

307. See Press Release, WIPO, WIPO Member States Agree To Fast-Track Work on Traditional Knowledge, WIPO Doc. PR/2003/362 (Sept. 29, 2003), at http://www.wipo.int/pressroom/en/releases/2003/p362.htm.

308. See Daniel Pruzin, WIPO Members Call Time Out in Talks on Global Patent Harmonization Treaty, 20 Int'l Rep. (BNA), No. 23, at 960 (June 5, 2003) (noting the "growing gap between developed and developing countries over the need to incorporate public health, environmental, and other societal concems in the draft" of the SPLT); Developing Countries Raise Biodiversity Concerns in WIPO, BRIDGES TRADE BIORES (Int'l Ctr. for Trade and Sustainable Dev., Geneva, Switz.), Dec. 11, 2002, at 3, http://www.ictsd.org/biores/02-12-11/biores 2-19.pdf (discussing proposals introduced by developing country governments during negotiations of SPLT to protect "public health, the environment ... [and] the protection of genetic resources and traditional knowledge"). Such concerns could be incorporated, for example, through a provision of the SPLT requiring patent applicants to disclose the country of origin of biodiversity-related innovation or traditional knowledge.

309. See GRAIN, World Patent System, supra note 107, at 4-5 \& n.6. Developing states have sought to include in the treaty a provision requiring biodiversity-related disclosures. 
How, then, will international intellectual property lawmaking change as a result of post-TRIPs regime shifting? The political terrain of a system in which the competence to create intellectual property protection rules is shared among multiple international venues is both more complex and more uncertain than a system in which negotiations occur in a limited number of fora. In particular, regime shifting destabilizes existing approaches to intellectual property protection and generates new dynamics of lawmaking, standard setting, and dispute settlement.

This Part identifies three such dynamics: (1) the incentives TRIPs creates for other regimes to develop new soft law norms; (2) the effect of intellectual property lawmaking in other regimes on TRIPs dispute settlement; and (3) strategic issues created by the division of developing countries' integrationist regime shifting proposals between the WTO and WIPO. These are by no means the only novel issues that post-TRIPs intellectual property regime shifting raises; its effects on national lawmaking, for example, also warrant scholarly scrutiny. But these three features are likely to occupy a central place in a legal and political order populated by a shifting mix of institutions, actors, and rules.

\section{A. TRIPs as an Incentive for Other Regimes To Develop Soft Law}

Conflicts over principles, norms, and rules are a vital force for regime change. In the area of intellectual property, states, NGOs, and officials of intergovernmental organizations have stressed the importance of avoiding such conflicts and of promoting consistency among an increasingly complex and overlapping set of treaty commitments and soft laws. ${ }^{310}$ Yet many of these same actors have also created new legal inconsistencies as a strategy for revising principles, norms, and rules they disfavor. ${ }^{311}$ In both instances, a key point of contention among actors is the identification of specific legal rules that are alleged to be in conflict.

The incentive that TRIPs creates for other international regimes to develop soft intellectual property law arises from these competing conflicts claims. Actors seeking to contest or roll back the recent expansion of intellectual property rights must identify with precision those rules that are in opposition to or at least in tension with particular provisions of TRIPs. One obvious way to create such oppositional rules, of course, is by drafting new international agreements. But treaties require protracted and time-consuming negotiations, and even when such negotiations occur they often produce rules that are ambiguous, incoherent, or articulated at a high level of generality. For this reason, state, nonstate, and intergovernmental actors often turn to the faster and more fluid mechanisms of soft law to fuel their conflicts claims.

The stimulus for generating soft law intellectual property norms is especially acute for framework or programmatic agreements such as the CBD

311. See supra Subsection IV.B.3 (discussing use of regime shifting to create counterregime 
and ICESCR that are drafted in permissive, gradualist language. ${ }^{312}$ Viewed solely at the level of treaty texts, it would be difficult to find any incompatibility between these agreements and TRIPs. Yet treaty text alone does not tell the entire story. Framework and programmatic agreements also contain mechanisms to develop more precise and exacting legal norms over time.

Consider the ICESCR as an example. The ICESCR Committee has issued a series of general comments that infuse the treaty with greater clarity and meaning. ${ }^{313}$ Although these interpretative statements do not bind states parties, they create widely shared expectations as to the meaning of the treaty's text. ${ }^{314}$ They also specify states' commitments in far greater detail than the treaty itself, for example by identifying certain "core obligations" for states to provide "at the very least, minimum essential levels of each of the rights" in the treaty. ${ }^{315}$ The concept of core obligations has enabled the Committee to adopt a "violations approach" to economic, social, and cultural rights, identifying concrete situations in which the failure to provide individuals with a particular level of goods or services amounts to a breach of a state's treaty commitments. ${ }^{316}$

In the area of intellectual property rights, recent general comments suggest that the Committee may soon interpret the ICESCR as guaranteeing a right of access to patented medicines - a right that may conflict with TRIPs. This access right derives from the right to health in Article 12 of the ICESCR. Paragraph 1 of that article requires states to "recognize the right of everyone to the enjoyment of the highest attainable standard of physical and mental health." States must take steps to achieve the full realization of this right, including steps necessary for "the prevention[,] treatment and control of epidemic ... diseases," and "the creation of conditions which would assure to all medical service and medical attention in the event of sickness.",317

312. See BRaITHWAITE \& DRAHOS, supra note 54 , at 262 (describing the CBD as a "framework convention"). Consider also the ICESCR, which requires states parties to "take steps, individually and through international assistance and cooperation, especially economic and technical, to the maximum of its available resources, with a view to achieving progressively the full realization of the rights recognized in the present Covenant by all appropriate means." ICESCR, supra note 205, art. 2(1), 993 U.N.T.S. at 5. These provisions principally establish programmatic and flexible commitments that are to be achieved over time. For a detailed analysis of states' obligations under ICESCR Article 2(1), see David Weissbrodt et al., International Human Rights: Law, Policy, and Process 88-93 (3d ed. 2001).

313. See WeISSBRODT ET AL., supra note 312, at 104-07 (discussing evolution of Committee's general comments).

314. See Matthew Craven, The International Covenant on Economic, Social and Cultural Rights: A PeRSPECTIVE ON ITS Development 91 (1995) ("Although the Committee's interpretations of the Covenant are not binding per se, it is undoubtedly true that they have considerable legal weight.").

315. General Comment No. 3-The Nature of States Parties' Obligations (Art. 2, Para. 1), U.N. ESCOR Comm. on Econ., Soc., \& Cultural Rts., 5th Sess., Supp. No. 3, para. 10, U.N. Doc. E/1991/23 (1991), http://lawhk.hku.hk/demo/unhrdocs/escgc3.htm. Core obligations are distinguishable from obligations of result, which states may achieve by a variety of means over time. Id.

316. Audrey R. Chapman, Conceptualizing the Right to Health: A Violations Approach, 65 TENN. L. REV. 389, 395 (1998).

317. ICESCR, supra note 205, art. 12(2)(c)-(d), 993 U.N.T.S. at 8. 
Based on the text of Article 12 and on periodic reports filed by states, ${ }^{318}$ the ICESCR Committee adopted a general comment on the right to health in May $2000 .^{319}$ The comment is a detailed exegesis on the human right to health, which the Committee interprets as including "the provision of essential drugs. ${ }^{, 320}$ In particular, each state is under a core, non-derogable obligation to "provide essential drugs, as from time to time defined under the WHO Action Programme on Essential Drugs." ${ }^{321}$ Governments are also required "to protect" the right to health by "tak[ing] measures that prevent third parties from interfering with article 12 guarantees," including interferences by the "private business sector." "322

The 2000 general comment does not mention patented pharmaceuticals or intellectual property rights, nor does it endorse a reading of the ICESCR that requires states to derogate from their TRIPs commitments to ensure access to essential drugs. However, in its November 2001 interpretive statement on human rights and intellectual property, ${ }^{323}$ the ICESCR Committee for the first time recognized a potential zone of inconsistency between the two treaties. The Committee "emphasize[d] that any intellectual property regime that makes it more difficult for a State party to comply with its core obligations in relation to health, food, education, especially, or any other right set out in the Covenant, is inconsistent with the legally binding obligations of the State party." 324 Inasmuch as the general comment on the right to health recognizes a core obligation "[t]o provide essential drugs"-an obligation that patent protection arguably makes more difficult in the short term-states may seize upon the Committee's statement to claim that patent protection for WHO-denominated essential drugs conflicts with their ICESCR commitments. This is not an implausible prediction. Developing countries sought to exclude such essential drugs from patentability prior to the Seattle Ministerial Conference, well before the Committee issued its interpretive statement. ${ }^{325}$

As this example reveals, the human rights concerns generated by TRIPs's expansion of intellectual property protection rules created incentives

318. ICESCR, supra note 205, art. 16, 993 U.N.T.S. at 9 (requiring states to submit periodic "reports on the measures they have adopted and the progress made in achieving the observance of the rights recognized" in the ICESCR).

319. General Comment No. 14-The Right to the Highest Attainable Standard of Health (Art. 12), U.N. ESCOR Comm. on Econ., Soc., \& Cultural Rts., 22d Sess. Agenda Item 3, para. 43, U.N. Doc. E/C.12/2000/4 (2000).

320. Id. para. 17.

321. Id. paras. 43(d), 47. See supra note 186 and accompanying text (describing WHO essential drugs policy).

322. Id. paras. 33, 42. According to the Committee, "[v]iolations of the obligation to protect follow from the failure of a State to take all necessary measures to safeguard persons within their jurisdiction from infringements of the right to health by third parties. This category includes such omissions as the failure to regulate the activities of individuals, groups or corporations so as to prevent them from violating the right to health of others ...." Id. para. 51.

323. ICESCR Statement on Human Rights and Intellectual Property, supra note 231.

324. Id. para. 12 (emphasis added). Further clarification of the potential inconsistencies between TRIPs and the ICESCR may be forthcoming when the Committee issues its general comment on intellectual property rights. Id. para. 2 (noting Committee's desire to prepare a general common on intellectual property rights "as soon as possible").

325. See, e.g., Venezuela Communication, supra note 269 , at 1.2 . 
for the Committee to develop new soft law that particularized the ambiguous obligations in the ICESCR. Those non-binding norms, in turn, add force to developing countries' efforts to harmonize TRIPs with the public health and human rights regimes by identifying specific inconsistencies for negotiators to reconcile. Nor is this dynamic of soft lawmaking unique to the ICESCR Committee. Similar incentives explain the CBD COP's drafting of the Bonn Guidelines, the WHO's suggestion of using TRIPs safeguards to achieve public health goals, and the work of the ITPGR's Governing Body in developing draft MTAs.

\section{B. Counterregime Norms and TRIPs Dispute Settlement}

One important consequence of moving intellectual property protection rules into the WTO is the ability to enforce them through a strong dispute settlement system. ${ }^{326}$ Since their earliest decisions, WTO panels and the Appellate Body have emphasized that their primary responsibility is to interpret the WTO agreements. ${ }^{327}$ But in undertaking this interpretive enterprise, dispute settlement jurists have refused to interpret the agreements in "clinical isolation" from other areas of international law. ${ }^{328}$ This raises the question of how WTO jurists will respond to claims that TRIPs is inconsistent with the treaty commitments and soft law norms of other international regimes. Although such claims of inconsistency may have substantial persuasive force when used to support treaty amendments or promote soft lawmaking, they are likely to be viewed quite differently when raised during a WTO dispute settlement proceeding.

\section{The Resolution of Treaty Conflicts by WTO Panels}

When interpreting all WTO Agreements, including TRIPs, WTO panels and the Appellate Body are required to apply the "customary rules of interpretation of public international law." ${ }^{329}$ These rules-which find their principal expression in the Vienna Convention on the Law of Treaties ${ }^{330}-$ presume that two treaties relating to the same subject matter are compatible

326. See supra Subsection II.C.2 (discussing consequences of moving intellectual property nules from WIPO to the WTO).

327. See Trachtman, WTO Dispute Resolution, supra note 256, at 342 (stating that the "mandate to WTO dispute resolution panels, to the Appellate Body, and to the Dispute Settlement Body is clear: apply (directly) only WTO law," and collecting supporting case law). But see Joost Pauwelyn, The Role of Public International Law in the WTO: How Far Can We Go?, 95 AM. J. INT'L L. 535, 577 (2001) (arguing that "non-WTO rules may actually apply before a WTO panel and override WTO rules").

328. WTO Appellate Body Report on United States-Standards for Reformulated Gasoline, at 17, WTO Doc. WT/DS2/AB/R (Apr. 29, 1996) (stating that WTO Agreements "are not to be read in clinical isolation from public international law"); see Gabrielle Marceau, $A$ Call for Coherence in International Law: Praises for the Prohibition Against "Clinical Isolation" in WTO Dispute Settlement, 33 J. WORLD TRADE 87 (1999) [hereinafter Marceau, $A$ Call for Coherence].

329. See GATT Multilateral Trade Negotiations (The Unuguay Round), Understanding on Rules and Procedures Governing the Settlement of Disputes, Dec. 15, 1993, art. 3.2, 33 I.L.M. 112 (1994).

330. Vienna Convention on the Law of Treaties, opened for signature May 23, 1969, U.N. Doc. A/Conf. 39/27, 1155 U.N.T.S. 321 (1980) [hereinafter Vienna Convention]. 
and can be implemented by a state that has ratified both agreements. According to recent WTO jurisprudence, a conflict exists only where treaty rules are mutually inconsistent, in the sense that a state's compliance with one rule necessarily compels it to violate another. ${ }^{331}$

Broader notions of inconsistency are not considered conflictual under this narrow, technical approach to treaty conflicts. ${ }^{332}$ For example, no conflict exists where an earlier treaty authorizes but does not compel a state to act in a certain way and a later agreement prohibits the very same action. By ratifying the second agreement, the state has restricted the authority granted to it under the first treaty. But it may still act in a way that avoids a breach of either commitment. ${ }^{33}$ It follows as a matter of course under this restrictive approach to conflicts that soft law is not on par with legally binding treaty obligations and thus can never excuse compliance with those obligations.

This brief overview of treaty conflicts jurisprudence reveals that WTO dispute settlement panels will give short shrift to arguments that compliance with a state's intellectual property obligations should be excused because TRIPs conflicts with provisions of the CBD, the ITPGR, or the ICESCR, or with soft law standards developed in the four regimes discussed in this Article. Because implementing TRIPs does not compel a violation of these agreements or standards (even though it may narrow the discretion or options available to states), WTO jurists are likely to reject claims that violating TRIPs is necessary to avoid a conflict with other treaty commitments or regime objectives. ${ }^{334}$

The fact that noncompliance with TRIPs cannot be excused on these grounds does not, however, preclude states from arguing that TRIPs should be interpreted in a manner that avoids such conflicts and harmonizes

331. See WTO Dispute Panel Report on Indonesia-Certain Measures Affecting the Automobile Industry, para. 14.28, WTO Docs. WT/DS/54/R, WT/DS55/R, WT/DS59/R \& WT/DS64/R (July 23,1998 ) ("noting that in public international law there is a presumption against conflict"); id. para. 14.28 n.649 ("[T]echnically speaking, there is a conflict when two (or more) treaty instruments contain obligations which cannot be complied with simultaneously. . . . Not every such divergence constitutes a conflict, however. . . Incompatibility of contents is an essential condition of conflict.") (quoting 7 ENCYCLOPEDIA OF PUBLIC INTERNATIONAL LAW 468 (1984)); see also WTO Appellate Body Report on Guatemala-Antidumping Investigation Regarding Portland Cement from Mexico, para. 65, WTO Doc. WT/DS60/AB/R (Nov. 25, 1998) ("A special or additional provision should only be found to prevail over a provision of the [Dispute Settlement Understanding] in a situation where adherence to the one provision will lead to a violation of the other provision, that is, in the case of a conflict between them."); Marceau, $A$ Call for Coherence, supra note 328, at $127 \mathrm{n} .131$ (collecting additional authorities).

332. That WTO jurists have defined treaty conflicts narrowly should not be misconstrued as obviating the need to resolve the broader legal and policy clashes that overlapping treaty commitments often generate. See generally Pauwelyn, supra note 112. To the contrary, the resolution of such clashes will simply migrate to other parts of the dispute settlement process, such as how to interpret a treaty in light of other international agreements, state practice, and tacit political understandings between the parties. For an insightful discussion, see John H. Knox, The Judicial Resolution of Conflicts Between Trade and the Environment, 28 HARV. ENVTL. L. REV. (forthcoming Winter 2004).

333. See Panel Report on Indonesia, supra note 331, para. 14.99 (rejecting claim that treaty obligations were in conflict where defending state was able to "respect its obligations" under one agreement "without violating" the other).

334. Cf. Gabrielle Marceau, WTO Dispute Settlement and Human Rights, 13 EUR. J. INT'L L. 753,792 (2002) ("[F]or a conflict to exist between a WTO provision and a provision of a human rights treaty, evidence must be put forward that the WTO mandates or prohibits an action that a human rights treaty conversely prohibits or mandates. Such situations would be rare."). 
international objectives. ${ }^{335}$ As I explain below, soft law will be an important tool for WTO panels to use in addressing such arguments.

\section{The Influence of Soft Law on WTO Panels}

The possibility that WTO jurists might use soft law to interpret TRIPs and other WTO agreements was raised by the Appellate Body in the Shrimp/Turtle case. ${ }^{336}$ One interpretive task facing the Appellate Body in Shrimp/Turtle was to determine the meaning of the phrase "exhaustible natural resources" in Article XX $(\mathrm{g})$ of the GATT-a provision that allows members to impose exceptions to GATT's free trade rules. Relying upon a reference in the WTO agreement's Preamble to "sustainable development," the Appellate Body concluded that "exhaustible natural resources" was an evolutionary concept to "be read by a treaty interpreter in the light of contemporary concerns of the community of nations about the protection and conservation of the environment." ${ }^{337}$ Those concerns, in turn, were reflected not only in treaties regulating natural resources but also in nonbinding "declarations" addressing that topic. ${ }^{338}$

A similar approach might be applied to "evolutionary" terms in TRIPs. Dispute settlement jurists would first consult treaties and soft law developed in other international regimes to ascertain the "contemporary concerns of the community of nations." These concerns would then aid in determining the meaning of any evolutionary provisions in TRIPs. ${ }^{339}$ Robert Howse advocates precisely this approach in his critique of the panel's decision in CanadaPatent Protection of Pharmaceutical Products (Generic Medicines). ${ }^{340}$

335. At least one TRIPs dispute settlement decision has expressly endorsed such harmonization efforts. In United States-Section 110(5), a case challenging a provision of the United States copyright statute known as the Faimess in Music Licensing Act, a panel was asked to interpret several articles of the TRIPs Agreement and the Berne Convention. In conducting this interpretive inquiry, the WTO jurists sought "contextual guidance" from the articles of the WIPO Copyright Treaty and its accompanying Agreed Statement, even though the treaty was not (at the time of the decision in 2000) binding on any state because it had not yet garnered a sufficient number of ratifications to enter into force. United States-Section 110(5) Dispute Panel Report, supra note 109, para. 6.70. The panel nevertheless viewed the treaty as part of the "overall framework for multilateral copyright protection" that should be consulted so as to "develop[] interpretations that avoid conflicts" within that framework. Id. A similar approach could be used, for example, to harmonize TRIPs with the ITPGR, which has been signed by more than six dozen states but has not yet entered into force. See supra note 184 (listing the number of signatures and ratifications of the ITPGR).

336. WTO Appellate Body Report on United States-Import Prohibition of Certain Shrimp and Shrimp Products, WTO Doc. WT/DS58/AB/R (Oct. 8, 1998) [hereinafter Shrimp/Turtle Appellate Body Report].

337. Id paras. $129,130$.

338. Id. para. 130 (citing Agenda 21 and the Resolution on Assistance to Developing Countries, adopted in conjunction with the Convention on the Conservation of Migratory Species of Wild Animals). The Appellate Body also referred to soft law to support the need for multilateral action to protect natural resources. Id. para. 168 (citing Agenda 21 and Rio Declaration on Environment and Development).

339. Which provisions qualify as evolutionary is an open question. Ian Sinclair states that such "relative or evolving notions" include "public policy" and "the protection of morals." SIR IAN M. SinClair, THE VienNa CONVENTION ON THE LAW OF TREATIEs 139 (2d ed. 1984).

340. Robert Howse, The Canadian Generic Medicines Panel: A Dangerous Precedent in Dangerous Times, 3 J. WORLD INTELL. PROP. 493 (2000) (critiquing Report of the Dispute Panel on Canada-Patent Protection of Pharmaceutical Products (Generic Medicines), WTO Doc. WT/DS1 14/R 
Howse asserts that in interpreting the patent exceptions clause in TRIPs Article $30,{ }^{341}$ the panel should have referred to TRIPs Article $8(1)$, which recognizes members' right to, inter alia, "adopt measures necessary to protect public health" provided that they are consistent with TRIPs. ${ }^{342}$ "Then, pursuant to Article 31.3.c of the Vienna Convention, to determine the meaning of 'necessary to protection public health', one would have recourse to relevant international health law," a body of rules that includes "'soft law' sources, such as resolutions and authoritative reports and policy statements of relevant international organizations." ${ }^{343}$ Had the panel referenced these soft law sources, according to Howse, it would have given "clear priority to the legitimate health interests in question over any competing interests of the rights holder," and interpreted TRIPs "in a manner consistent with what is required for the protection of public health, as defined by world health policy., 344

Howse identifies a clear roadmap for using soft law to interpret TRIPs, an issue that WTO jurists have yet to address directly. ${ }^{345}$ But it is uncertain whether the Appellate Body's analysis in the Shrimp/Turtle case can be extended this far. As an initial matter, Article 31(3)(c) of the Vienna Convention requires panels to "take[] into account . . . any relevant rules of international law applicable in the relations between the parties." ${ }^{346}$ Nonbinding resolutions and policy statements do not fall within this definition, although they may provide evidence of a political agreement among states to which WTO jurists may feel inclined to defer ${ }^{347}$ Soft law may also serve as a foundation for the evolution of binding international custom, which is accepted as a rule of international law. ${ }^{348}$ But WTO jurists have thus far

(Mar. 17, 2000)). In the Generic Medicines case, a WTO dispute settlement panel considered a complaint brought by the EC against two provisions of Canada's patent law. The first permitted uses of patented pharmaceuticals without the patent owner's authorization for the purpose of obtaining approval of a generic product before the patent term expired. The second permitted production and stockpiling of generic drugs during the term of patent protection so that the drugs could be released immediately after the expiration of the patent term. Both provisions were intended to promote the prompt marketing of generic versions of pharmaceuticals after their patent term had expired. The panel decision held that only the first of these exceptions was consistent with TRIPs. Id. at 494-95. Neither the EC nor Canada appealed the panel's ruling to the Appellate Body, a ruling that the WTO Dispute Settlement Body later adopted. $I d$. at $494 \mathrm{n} .5$.

341. TRIPs, supra note 1, art. 30, 33 I.L.M. at 95 ("Members may provide limited exceptions to the exclusive rights conferred by a patent, provided that such exceptions do not unreasonably conflict with a normal exploitation of the patent and do not unreasonably prejudice the legitimate interests of the patent owner, taking account of the legitimate interests of third parties.").

342. Id. art. $8(1)$, at 87 .

343. Howse, supra note 340 , at 504 .

344. Id. at 505 .

345. Recall, however, that the panel in the United States-Section 110(5) case viewed the notyet-in-force WIPO Copyright Treaty as an important part of the "overall framework for multilateral copyright protection," a fact that suggests an openness to using soft law to interpret TRIPs. United States-Section 110(5) Dispute Panel Report, supra note 109, para. 6.70. I thank Graeme Dinwoodie for this insight.

346. Vienna Convention, supra note 330 , art. 31(3)(c), 1155 U.N.T.S. at 340 (emphasis added).

347. See Knox, supra note 332 (manuscript at 51-80).

348. See David J. Bederman, International Law Frameworks 96 (2001) (noting that “"soft' law has a tendency, over time, to harden into international legal obligation"); C.M. Chinkin, The Challenge of Soft Law: Development and Change in International Law, 38 INT'L \& COMP. L.Q. 850, 856-59 (1989) (discussing different ways in which soft law evolves into customary international law). 
eschewed deciding when this often-contested transformation from soft to hard law occurs. ${ }^{349}$

In addition, both treaty law and non-binding declarations bolstered the Appellate Body's interpretations in the Shrimp/Turtle case. ${ }^{350}$ Whether WTO jurists would give similar interpretive weight to soft law alone is uncertain. Moreover, even were the Appellate Body willing to rely exclusively on nonbinding principles to add interpretive color to TRIPs, it would first need to determine which of the treaty's provisions embody "evolutionary" principles that justify a reference to post-TRIPs legal developments. Although the important if open-ended reference in Article 8(1) to "measures necessary ... to promote the public interest in sectors of vital importance to [members'] socio-economic ... . development" ${ }^{\text {"351 }}$ would seem to qualify, the more detailed intellectual property protection rules in Part II of TRIPs might not. At a minimum, however, Shrimp/Turtle is likely to invite competing arguments from states as to how WTO panels should (or should not) take soft law norms generated outside the trade regime into account when interpreting the TRIPs Agreement.

\section{Regime Shifting Redux: WTO or WIPO?}

As explained above, developing countries, in addition to creating counterregime norms in the biodiversity, PGR, public health, and human rights regimes, are seeking to integrate those norms into the treaty negotiations and soft lawmaking processes of the WTO and WIPO. ${ }^{352}$ The parallel intellectual property lawmaking activities occurring in these two fora raise numerous questions of strategy.

Consider first the position of those industrialized states that hope to defeat developing countries' proposals to amend TRIPs. ${ }^{353}$ Rather than (or in addition to) resisting these amendments on their own terms, these states may be using the WIPO IGC as a kind of safety valve ${ }^{354}$ to shunt issues away from the WTO and thereby reduce pressure from developing countries to address those issues in the WTO. Once an issue has been taken up by the IGC, industrialized states could then oppose TRIPs amendments on ripeness grounds, at least until the IGC had concluded its review.

The EC appears to have adopted just such an approach. In an April 2001 submission to the TRIPs Council, it endorsed the IGC as the appropriate

349. See WTO Appellate Body Report on Measures Concerning Meat and Meat Products (Hormones), para. 123, WTO Doc. WT/DS/26, 48 (Jan. 16, 1998) (stating that it was "unnecessary, and probably imprudent, for the Appellate Body" to decide whether the "precautionary principle" had ripened into a rule of customary international law); Marceau, $A$ Call for Coherence, supra note 328, at 139 ("The biggest difficulty in dealing with concepts such as international customs or general principles of international law, is ... to define them and their limits.").

350. Shrimp/Turtle Appellate Body Report, supra note 336, para. 130 (noting that "modern international conventions and declarations make frequent references to natural resources as embracing both living and non-living resources") (emphasis added).

351. TRIPs, supra note 1, art. 8(1), 33 I.L.M. at 87.

352. See supra Sections V.A.V.C.

353. See supra Part V (discussing developing states' integrationist regime shifting strategy).

354. See supra Subsection IV.B.2 (discussing the use of regime shifting as a safety valve). 
forum in which to develop "an international model for the legal protection of traditional knowledge." Support for such a model in WIPO, however, meant that review in the WTO should be delayed: "Once a model is in place, attention can then be focused on how and to what extent the protection of traditional knowledge can be included in the TRIPS Agreement." ${ }^{355}$ The EC paper also opposed amending TRIPs to impose CBD-related conditions on patent applicants. It did, however, express a willingness to discuss such conditions "within the appropriate fora," strongly suggesting that such negotiations should occur in WIPO. ${ }^{356}$

Within the IGC itself, industrialized states could also seek to slow the progress of work, shape studies to favor their interests, or block any recommendations they oppose.$^{357}$ Since the pace of the IGC's activities is not linked to the WTO's negotiating schedule, these efforts may allow the Doha round of trade talks to close before the IGC completes its work. ${ }^{358}$ Timing aside, any recommendations endorsed by the IGC and approved by the WIPO General Assembly would be non-binding and might not be suitable for transposition into the TRIPs Agreement, a binding treaty with a strong dispute settlement system.

In light of these strategies, why have some developing country governments nevertheless endorsed the IGC as a forum for integrating new intellectual property protection standards into WIPO? Recall that developing states initially argued that such standards should be included within the Patent Law Treaty, a proposal that industrialized states vigorously opposed. ${ }^{359}$ The IGC was a compromise offered by the WIPO Secretariat. The new Committee might thus be seen as its own form of safety valve for industrialized states,

355. EC Communication, supra note 273, para. 27 (emphasis added).

356. Id. para. 23. In September 2002, the EC agreed to negotiations in the TRIPs Council on "a self-standing disclosure requirement, that would allow [WTO] Members to keep track, at [the] global level, of all patent applications with regard to genetic resources for which they have granted access." $E C$ Concept Paper, supra note 289, para. 51. Unlike developing countries, however, the EC opposes treating such disclosures as an eligibility criterion for patent protection. Id. para. 55 .

357. Although the EC has expressed support for the IGC's work, it has also suggested that all of its decisions "should be carefully considered." Report of WIPO Intergovernmental Committee on Intellectual Property and Genetic Resources, Traditional Knowledge, and Folklore, 1st Sess., para. 20, WIPO Doc. WIPO/GRTKF/IC/1/13 (May 23, 2001) [hereinafter IGC First Session Report] (Delegation of Sweden, speaking on behalf of the EC). Statements by the United States and Japan express more skepticism and the need for a "go slow" approach. See id. para. 49 (Delegation of the United States expressed doubt that it would be "possible, or even desirable, to establish a comprehensive, uniform set of rules at the international level to govern the use of genetic resources, traditional knowledge and folklore"); WIPO Assembly Report, supra note 302, para. 34 (Delegation of Japan stated that "issues should be discussed without prejudging the outcome of the work of the Committee" and proposed that "the work commence with a sharing of experiences among all Member States to define and delimit the scope of the issues").

358. The Doha round of negotiations is scheduled to conclude before January 1, 2005. Doho Ministerial Declaration, supra note 13, para. 45. At present, however, that date seems unduly optimistic, particularly after the breakdown of trade talks in Cancún. See The WTO Under Fire, supra note 293, at 27-28. Moreover, developing countries have recognized the strategic implications of the different time frames for action in the WTO and WIPO. See 2003 Africa Group Communication, supra note 290, at 5 (noting that "work in WIPO on genetic resources and traditional knowledge has been very slow, and ... it would therefore not be appropriate to defer action under the mandate on [TRIPs] Article 27.3(b), which has a time frame, until WIPO completed its work").

359. See supra Section V.C (discussing formation of IGC). 
from WIPO's more consequential treaty negotiations-and in particular its patent harmonization efforts-to its less threatening soft law processes. ${ }^{360}$

But developing states may also believe that they can benefit from the IGC's work in several important ways. First, the Committee is facilitating their efforts to create coherent intellectual property norms relating to resources-such as PGRs and traditional knowledge-for which they enjoy a comparative advantage over industrialized countries. ${ }^{361}$ If their proposals to amend TRIPs to protect these resources are blocked in the politically charged atmosphere of the WTO, the IGC offers an opportunity to use WIPO's technical expertise to gather information and develop concrete and wellreasoned proposals. Because of the IGC's more porous observer status rules, this work can also draw upon contributions from knowledgeable and sympathetic NGOs and intergovernmental organizations. ${ }^{362}$ Second, developing states are themselves divided over some of the issues within the IGC's mandate, such as the rules best suited to protect traditional knowledge. ${ }^{363}$ The WIPO IGC offers a safer space than the WTO in which to work out these disagreements among allies. Third, some of the IGC's work-such as the collection of model clauses for MTAs or databases of traditional knowledge for consultation by national patent examiners ${ }^{364}$-would benefit developing countries without having to be included in a treaty. Finally, the IGC process could legitimize developing countries' concerns. Any of the Committee's recommendations that WIPO member states later adopted, unlike proposals generated in other international regimes, would bear the imprimatur of an organization charged with "promot[ing] the protection of intellectual property throughout the world." 365

In sum, both industrialized and developing states had reasons to support the IGC's work. Whether that support will continue over time will depend on which proposals the Committee endorses and on the progress of treaty negotiations underway within the WTO and WIPO.

\section{CONCLUSION}

Within the last five years, international intellectual property lawmaking has broken out of the confined institutional spaces of WIPO and the WTO and permeated deeply into international regimes concerning biodiversity, plant

360. See IGC First Session Report, supra note 357, para. 41 (The delegation of Japan stressed that the IGC's work, in contrast to that of the Standing Committee on the Law of Patents, was not intended "to mak[e] new rules such as a treaty."); GRAIN, ONE GLOBAL PATENT SYSTEM, supra note 250, at 2-14 (discussing the significance of on-going SPLT negotiations in WIPO).

361. See Pires de Carvalho, supra note 121, at 395 (noting that "biodiversity and the knowledge of its use in a sustainable manner are the comparative advantage of developing countries in international trade").

362. IGC First Session Report, supra note 357, paras. 2-3 (listing observers at first IGC meeting); Report of WIPO Intergovernmental Comm. on Intellectual Prop. and Genetic Res., Traditional Knowledge, and Folklore, 2d Sess., paras. 3-4, WIPO Doc. WIPO/GRTKF/IC/2/16 (2001) (listing observers at second IGC meeting).

363. For a discussion of different options, see IGC Overview, supra note 120, paras 63-87.

364. See IGC Moves Ahead, supra note 306 (noting efforts to create these databases during IGC's third meeting).

365. WIPO Convention, supra note 42, art. 3(i), 21 U.S.T at 1772, 828 U.N.T.S. at 11. 
genetic resources, public health, and human rights. In that same period, the TRIPs Agreement has come under increasing challenge, especially but by no means exclusively from developing countries and NGOs. This Article links these two phenomena. It argues that the recent expansion of intellectual property lawmaking into new international venues is the result of regime shifting by state and nonstate actors who are dissatisfied with many of the intellectual property treaty bargains negotiated by WTO members and are actively seeking ways to revise or supplement them.

Regime shifting has been a pervasive feature of international intellectual property lawmaking at least since the shift from WIPO to GATT to TRIPs. But its recent use by developing countries has not been fully explored. This Article remedies that omission. It shows how developing nations, aided by NGOs and officials of intergovernmental organizations, have used regime shifting to serve different normative and strategic goals. These include moving to regimes whose institutions, actors, and decision-making procedures are more conducive to achieving desired policy outcomes, relieving pressure by domestic interest groups for lawmaking in other regimes, generating counterregime intellectual property norms in tension with TRIPs, and developing concrete proposals to be integrated into the WTO and WIPO.

Although regime shifting is an interesting dynamic of international relations in its own right, it also has important consequences for the future development of intellectual property rights. A system in which the boundaries of discrete, decomposable regimes are eroding and principles, norms, and rules of intellectual property protection are forged in what is rapidly becoming a conglomerate-type regime is very different from a system in which negotiations occur in a small number of venues. In particular, the division of authority and competition among fora that regime shifting may engender creates both opportunities and risks. It opens up lawmaking and dispute settlement to new perspectives and avenues of influence, it creates new venues for states to bargain and to link issue areas, and it generates new forms of cooperation among intergovernmental bodies with different institutional strengths. But regime shifting may also spawn inefficient rivalries among actors or attenuate mechanisms for holding international institutions accountable to affected constituencies. And it increases the likelihood of conflicting or incoherent legal obligations for states and private parties-an especially grave concern for an international system with few hierarchical rules for resolving such inconsistencies.

Whether the opportunities or the risks of intellectual property regime shifting-or regime shifting generally-will predominate in the future is still unknown. This Article has identified the pathways along which regime shifting is likely to develop, but the endpoints of those pathways are by no means foreordained. Indeed, as hegemons have become more attuned to developing countries' use of this strategy, they are responding with fresh rounds of intellectual property regime shifting, this time to regional and 
bilateral arrangements ${ }^{366}$ and to fora within existing multilateral institutions. ${ }^{367}$ The outcome of these competing strategic initiatives will depend on how negotiations and lawmaking in these and other diverse international fora evolve over the next several years, on the power differentials created by changes in the geo-strategic landscape, and on the capacity and the desire of governments, NGOs, and intergovernmental officials to secure the benefits of cooperation while avoiding the dangers of conflict.

366. See Andrews, supra note 60, at C1 (discussing United States' "new strategy" of trade bilateralism and regionalism); GRAIN, TRIPs-plus, supra note 10, at 2-3 (discussing bilateral treaties containing standards that exceed those in TRIPs).

367. See GRAIN, ONe Global Patent System, supra note 250, at 3-17 (highlighting importance of SPLT negotiations and WIPO's patent agenda for developing countries). 
